\title{
Pesticides With Potential Thyroid Hormone-Disrupting Effects: A Review of Recent Data
}

\section{OPEN ACCESS}

Edited by:

Marco António Campinho,

University of Algarve, Portugal

Reviewed by:

Joanne F. Rovet,

Hospital for Sick Children, Canada

Gemma Calamandrei,

National Institute of Health, Italy

${ }^{*}$ Correspondence:

Jean-Baptiste Fini

fini@mnhn.fr

Michelle Leemans

michelle.leemans@mnhn.fr

Specialty section:

This article was submitted to

Thyroid Endocrinology,

a section of the journal

Frontiers in Endocrinology

Received: 29 April 2019

Accepted: 14 October 2019

Published: 09 December 2019

Citation:

Leemans M, Couderq S, Demeneix B and Fini J-B (2019) Pesticides With Potential Thyroid Hormone-Disrupting

Effects: A Review of Recent Data.

Front. Endocrinol. 10:743.

doi: 10.3389/fendo.2019.00743

\author{
Michelle Leemans*, Stephan Couderq, Barbara Demeneix and Jean-Baptiste Fini* \\ Muséum National d'Histoire Naturelle, CNRS UMR 7221, Laboratoire Physiologie moléculaire de l'adaptation, Paris, France
}

Plant Protection Products, more commonly referred to as pesticides and biocides, are used to control a wide range of yield-reducing pests including insects, fungi, nematodes, and weeds. Concern has been raised that some pesticides may act as endocrine disrupting chemicals (EDCs) with the potential to interfere with the hormone systems of non-target invertebrates and vertebrates, including humans. EDCs act at low doses and particularly vulnerable periods of exposure include pre- and perinatal development. Of critical concern is the number of pesticides with the potential to interfere with the developing nervous system and brain, notably with thyroid hormone signaling. Across vertebrates, thyroid hormone orchestrates metamorphosis, brain development, and metabolism. Pesticide action on thyroid homeostasis can involve interference with $\mathrm{TH}$ production and its control, displacement from distributor proteins and liver metabolism. Here we focused on thyroid endpoints for each of the different classes of pesticides reviewing epidemiological and experimental studies carried out both in in vivo and in vitro. We conclude first, that many pesticides were placed on the market with insufficient testing, other than acute or chronic toxicity, and second, that thyroid-specific endpoints for neurodevelopmental effects and mixture assessment are largely absent from regulatory directives.

Keywords: thyroid hormones, pesticides, endocrine disruptors, organochlorine, organophosphates, pyrethroids, neonicotinoids, neurodevelopment

\section{BACKGROUND}

Plant Protection Products (PPPs) (herein referred to as pesticides) are used to control noxious pests and disease causing organisms including insects, fungi and unwanted plants (1) (EU Commission ${ }^{1}$ ). A major shift from inorganic pesticides, such as lead arsenate, to synthetic organic chemicals occurred in the late 1940s. These approaches revolutionized pest control efficiency to such a degree that synthetic pesticides were rapidly integrated into the ongoing industrialization of agriculture, public health programs and use by individuals. The revolution in industrial farming increased crop production and quality, with ensuing global production of synthetic pesticides escalating at a yearly rate of $10 \%$ from the 1950s, reaching upwards of 3 million tons by the turn of the century and 4 million tons in 2016 (2-4). Along with increasing production volumes, numerous synthetic pesticides appeared on the market, often due to development of acquired resistance by target species and/or regulatory restrictions brought by health or environmental concerns. The first synthetic pesticides introduced in the 1940s were the organochlorine pesticides (OCP), followed by organophosphates (OP) in the 1960s and carbamates in the 1970s. Pyrethroid production

${ }^{1}$ https://ec.europa.eu/food/plant/pesticides_en 
began in the 1980s, with the more recent compounds such as neonicotinoids and phenylpyrazoles being added in the 1990s (5).

Despite the early warnings of Rachel Carson in 1962, the intensity of pesticide use placed an increasing burden on the environment with limited consideration for the full extent of consequences. Acute or chronic exposure to a variety of pesticides occurring through cutaneous, respiratory or dietary routes are supported by current human biomonitoring efforts as well as studies on wild-life $(6,7)$. Simultaneously, a substantial body of evidence confirming the adverse health effects and ecological impact of PPP (including biocides) has been accumulating since the 1960s when pesticides, once heralded as a "magic bullet," made usage more controversial.

Carson's premonition of the impact of the organochlorine insecticide $\mathrm{DDT}^{2}$ on eggshell thinning in birds was later shown to be caused by endocrine-mediated effects, specifically, the estrogenic action of DDT's main metabolite $\mathrm{p}, \mathrm{p}^{\prime}-\operatorname{DDE}^{3}(8,9)$. The term "endocrine disruptor" gained traction in the early $90 \mathrm{~s}$ when used to describe the interference of several man-made chemicals, including certain pesticides, on estrogen, androgen, thyroid and steroid pathways $(10,11)$. While the acute toxic effects of pesticides on target, non-target species or occupational workers are quite well-documented (12-14), the effects of low doses relevant to concentrations assessed in foodstuffs and the environment are relatively neglected. Traditionally, regulatory systems rely on dose-response models and determine a threshold for safe levels of exposure, but potentially overlook the presence of non-monotonic dose-response curves below the toxicological no-observed-adverse-effect level (NOAEL) (15). This issue is particularly important given that many pesticides act as endocrine disrupting chemicals (EDCs), capable of interfering with natural hormones even at low doses and hence affect the normal development and function of multiple organs (16-19). Additionally, EDCs may exert specific effects during sensitive time-windows of development with adverse health outcomes occurring later in life-bringing the matter of timing of exposure during vulnerable periods, such as prenatal or postnatal life, increasingly into focus in both regulatory and fundamental research $(20,21)$.

\section{OVERVIEW OF THE HYPOTHALAMUS-PITUITARY-THYROID AXIS}

During the last 30 years insights into the role of thyroid hormones $(\mathrm{TH})$ at different levels of biological organization have contributed to a better physiological understanding of their function. In humans, TH is essential for the development of the brain, inner ear, eye, heart, kidneys, bone and skeletal muscle, amongst other tissues (22), but also for fine regulation of energy metabolism (23). The essential role of $\mathrm{TH}$ during vertebrate development has been amply reviewed (24-26), however

${ }^{2}$ dichlorodiphenyl trichloroethane (DDT)

${ }^{3} \mathrm{p}, \mathrm{p}$-dichlorodiphenyl dichloroethylene (p,p'-DDE). neurodevelopment warrants special attention. Strikingly, THs are crucial for normal brain development which is dramatically illustrated by cretinism, a syndrome induced by a severe lack of $\mathrm{TH}$ or iodine during embryo-fetal and post-natal development (27). In addition, disruption at any of the multiple levels along the hypothalamus-pituitary-thyroid axis (HPT-axis) axis during this vulnerable period of development, particularly early pregnancy $(28,29)$ can lead to deleterious effects on offspring IQ. These effects can be exerted through modifications of $\mathrm{TH}$ levels in the blood stream and within specific tissues, with subsequent modulation of TH-dependent actions in the nervous system (transcription, proliferation, neurogenesis, gliogenesis, migration), resulting potentially in altered brain structure and behavior $(19,28)^{4}$.

To summarize $\mathrm{TH}$ production and physiology very succinctly, TH synthesis in the thyroid colloid requires iodine, which circulates as iodide ion. In the thyroid gland, iodide is combined with the amino acid tyrosine to produce thyroxine (T4) or triiodothyronine (T3). Synthesis of THs (T4 and T3) is tightly controlled by the HPT-axis. The hypothalamus produces thyrotropin-releasing hormone (TRH), which triggers production of thyroid stimulating hormone (TSH) by the anterior pituitary. TSH is released into the bloodstream and binds to receptors on thyroid follicular cells of the thyroid gland. TSH stimulates iodide uptake mediated by the sodium/iodide symporter (NIS). After oxidation of iodide by thyroperoxidase (TPO), organification of iodide which consists of incorporation of iodide into thyroglobulin ( $\mathrm{Tg}$ ) is required to produce precursors of T3 and T4 (30). THs exert negative feedback on their upstream regulators thereby controlling hormone levels. Increases in T3 or T4 inhibit production of TSH and TRH by the pituitary and hypothalamus, respectively. Inversely, as T3 and T4 decrease, TSH and TRH genes are activated (31). In the bloodstream, THs are almost entirely bound to serum distributing proteins, such as transthyretin (TTR), albumin or thyroxin-binding globulin (TBG). Less than $0.001 \%$ of total T4 and T3 are available as free T4 or T3 (FT4 or FT3) and can enter cells through trans-membrane-transporters. Several transporters carry THs, including monocarboxylate transporters (MCTs), several members of the organic anion-transporting polypeptide (OATP) family $(32,33)$ and the heterodimeric L-type amino acid transporters (LATs). Intracellular TH availability is regulated in a dynamically and tightly coordinated manner by specific deiodination processes. Deiodinases type land 2 (D1 and D2) activate THs whereas D3 carries out inactivation of T4 and T3 (34). Lastly, THs can either positively or negatively regulate gene transcription via the thyroid hormone receptor (THR) by binding to thyroid hormone response elements (TREs) located on the promotors of target genes or even via direct modulation of gene expression (35). THRs are encoded by the thyroid hormone receptor $\alpha$ (THRA) and thyroid hormone receptor $\beta$ (THRB) genes each with specific transcriptional responses $(36,37)$.

Clinical assessment of thyroid function requires measurement of TSH. Elevated levels of TSH (and most often) simultaneously low TH indicate hypothyroidism, whereas suppressed TSH and

${ }^{4}$ World Health Organization. 
high TH suggest a hyperthyroid condition. Subclinical hypo- and hyperthyroidism are characterized by $\mathrm{TH}$ values in the reference range and, respectively, high or low TSH (38). TSH is currently considered to be the most sensitive indicator of thyroid status, although assays and interpretations of thyroid function tests are not always straightforward, especially in the case of discordant results, notably with T4 or FT4 $(39,40)$.

Epidemiological studies report associations between TSH and/or $\mathrm{TH}$ as a function of exposure to numerous persistent as well as non-persistent pesticides. Similarly, experimental evidence suggests that pesticides may act as thyroid disruptors, affecting the HPT axis at several levels: central regulation, iodine uptake, production and distribution of THs, or binding of $\mathrm{TH}$ to membrane transporters or receptors (41-43). As a consequence, pesticide disruption of the HPT axis is increasingly scrutinized in Europe and in the United-States. In 2013, the European Food Safety Agency (EFSA) reported that 101 of the 287 pesticides they examined had the potential to interfere with thyroid function (44). As to the socio-economic costs of EDCs, in 2015 the neurobehavioral deficits (principally IQ loss) and neurodevelopmental diseases including attention deficit/hypoeractivity disorder (ADHD), induced by three substances with endocrine disrupting properties and acting principally on thyroid signaling, was estimated at 157 billion euros in the European Union (EU) (29). Of this 157 billion, 120 billion were attributed to organophosphate pesticides, such as chlorpyrifos.

Several reviews have shown that many xenobiotics from different chemical classes, including PPPs, are potential TH axis disrupting compounds acting at different levels of the HPTaxis $(45,46)$ but none has recently addressed different pesticide classes. Current knowledge regarding the full impact of pesticides on human thyroid function is still limited (47-49). To fill this gap, we reviewed the latest research on thyroid-related endpoints associated with old and newly formulated pesticides. The strategy is shown in Figure $\mathbf{1}$ and is detailed in the Methods section as well as in Supplementary Material.

\section{METHODS}

A literature search of scientific literature was carried out using PubMed (on the 21st of March 2019) for references on pesticides and thyroid endpoints. Studies that contained both a pesticide term and a TH outcome in the title and/or abstract were included. A total of 232 articles were retrieved.

Search terms combined an extensive list of thyroid endpoints and pesticide-related terms varying from broad (e.g., insecticides) to more specific (e.g., permethrin) terms. Chemical groups of pesticides were based on those widely used and we added certain substances from the EU's Pesticides Database ${ }^{5}$ Yale MeSh Analyser ${ }^{6}$ was used to add specific Mesh terms possibly omitted during preliminary searches. Searches compiled two parenthetical terms ( $\mathrm{TH}$ outcome/pesticides) with an AND operator. These parenthetical terms contained sub-terms linked

${ }^{5}$ http://ec.europa.eu/food/plant/pesticides/eu-pesticides-database

${ }^{6} \mathrm{http}: / /$ mesh.med.yale.edu/ to each other via OR operators. The final search query is consultable in Table S1.

As the major aim of this review was to provide recent research conducted on pesticide exposure with thyroid-related adverse outcomes, the search in PubMed was limited to the last 5 years and involved two screening stages. A first selection was conducted on the title and abstract, and the second screening was based on full-text analysis. When uncertainty arose regarding the eligibility of a publication from its abstract, the full-text version of the article was retrieved to ensure that there was no inappropriate selection, e.g. "organochlorine" includes a diverse family of chemicals, some of which are not used as pesticides. The study selection was restricted to English-language articles. After analysis of title and abstract, 140 publications were retained for further analysis based on the full article. After excluding research that failed to meet the inclusion norms, a total of 46 publications was selected. The flowchart of the literature selection is presented in Figure 1. The references retrieved are organized by eligibility and classes of pesticides in an excel file accessible in Table S1.

In order to provide a more exhaustive overview, reference lists of included articles were also screened by title and abstract in order to include additional relevant articles without restrictions on their date of publication.

\section{ORGANOCHLORINE PESTICIDES}

OC pesticides (OCPs) are chlorinated hydrocarbon compounds, which were used extensively worldwide from the 1940s to the 1960s. They are considered to be the first generation of synthetic broad-spectrum pesticides, of which the most notable representatives are the insecticide DDT and the fungicide Hexachlorobenzene (HCB). OCPs represent a large class of chemicals which can be divided into dichlorodiphenylethanes (DDT, dicofol, and methoxychlor), hexachlorocyclohexanes ( $\mathrm{HCH}$ such as $\mathrm{HCB}$, chlordane, lindane), cyclodienes (aldrin, dieldrin, endrin, endosulfan, heptachlor), and toxaphene, a complex mixture of highly chlorinated bornanes, as well as mirex and its derivative chlordecone (50-52). Their action stems from their capacity to alter ion exchange in nerve axons in the peripheral and central nervous system, resulting in decreased action potentials but the precise mechanisms of action are diverse and remain mostly unknown. Cyclodienes have the added effect of competitively binding to the GABA-A receptor (53).

DDT was widely applied to both US military and civilian populations during the Second World War to combat malaria, typhus and other insect-borne diseases (54). Given its efficiency and low-cost, DDT was excessively applied in the agricultural sector for crop and livestock protection, as well as in homes and gardens (54). In the 1950s, production reached 100,000 tons per year in the US (55) until Carson's Silent Spring (56) brought OCP's toxic effects on non-target wild-life species as well as humans to the fore of public scrutiny. Public concern led to the creation of the US EPA in 1970 and shortly after, the ban of many OCPs for agricultural use. In 2001, the international Stockholm Convention singled out 12 compounds as Persistent Organic Pollutants (POPs), 9 of which were OCPs 


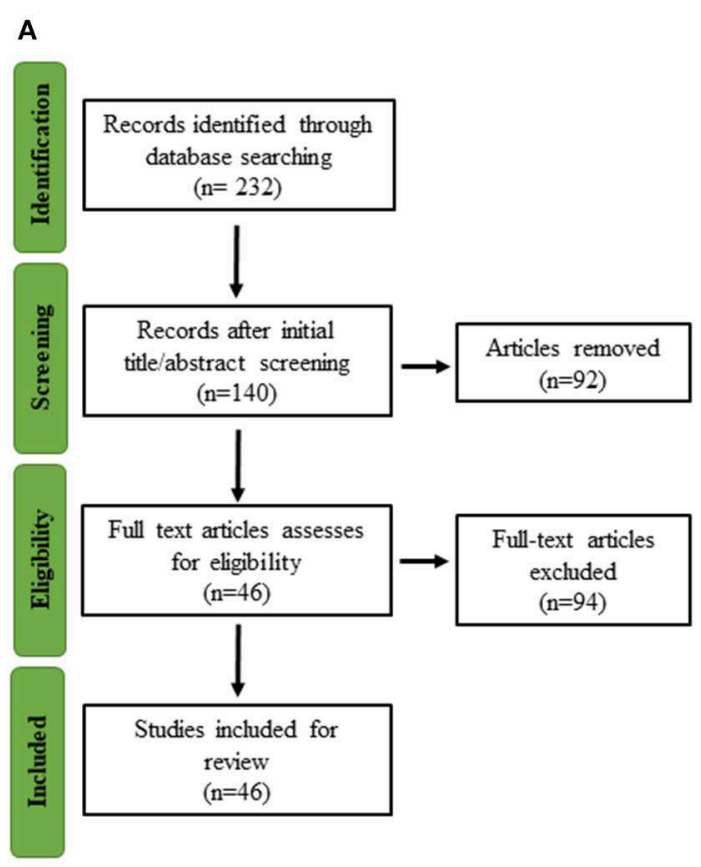

B

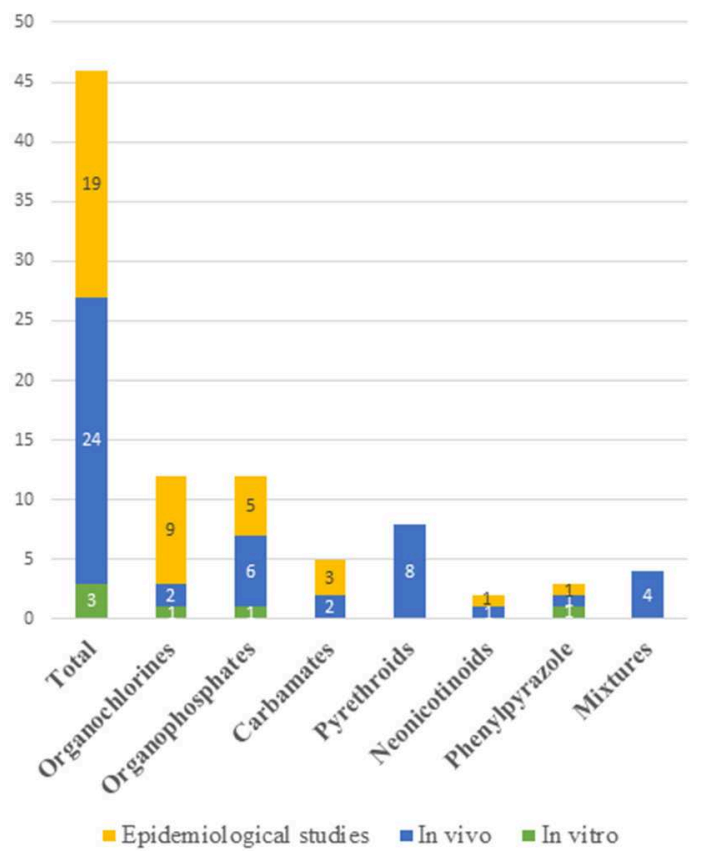

FIGURE 1 | (A) Flowchart of study selection. (B) Graphical representation of the 46 included studies organized by compound and type of study.

[UNEP (57), "12 initial POPs"]. Despite the ban, OCs remain a widespread environmental pollutant due to their resistance to environmental degradation, bioaccumulation in lipid-rich tissues, and biomagnification in the food chain $(58,59)$.

\section{Epidemiological Evidence of Thyroid Disruption}

Because DDT, HCB, and other OCPs have been associated with impaired neurodevelopment and neurocognition in infants and children (60-69), numerous epidemiological studies have investigated whether these adverse effects could be mediated, at least in part, by disruption of the HPT axis in either pregnant women or newborns (70-72, 72-81). An overview of the epidemiological organochlorine studies can be found in Table 1.

A Canadian birth-cohort study $(n=101)$ studied several OCs in pregnant women and observed that $\mathrm{p}, \mathrm{p}^{\prime}-\mathrm{DDE}$, the main metabolite of DDT, HCB and a constituent of chlordane were negatively associated with total T3 (TT3) levels, and $\beta-\mathrm{HCH}$ with FT4 (78). At 12 weeks of pregnancy, higher concentrations of $\mathrm{p}, \mathrm{p}^{\prime}$-DDE in maternal serum $(n=157)$ was associated with lower FT4 levels and higher TSH levels (82). In an exploratory cross-sectional study of 17 OCPs in neonates in China, Luo et al. (77) examined cord plasma concentrations $(n=115)$ of $\mathrm{HCHs}$, $\mathrm{p}, \mathrm{p}^{\prime}$-DDE and methoxychlor, and reported a negative association with FT4 levels. Other OCPs, such as aldrin and dieldrin, sum of DDTs and its metabolites, as well as the sum of OCPs were correlated with increases in TSH levels. In a small study of a farming population in northern Thailand $(n=39)$, cord serum levels of $\mathrm{p}, \mathrm{p}^{\prime}$-DDT and $\mathrm{p}, \mathrm{p}^{\prime}$-DDE were negatively associated with cord serum TT4 (71).
In a study on POPs in Korea $(n=104)$ by Kim et al. (76), $\beta$ $\mathrm{HCH}$, chlordanes, DDT, and $\mathrm{p}, \mathrm{p}^{\prime}$-DDE measured in mothers or in cord serum were associated with either decreased TH levels or increased TSH levels. Specifically, maternal p, $\mathrm{p}^{\prime}$-DDE was associated with decreased FT3, FT4, and TT4 in cord serum and was identified as a predominant determinate of bloodspot TSH with an interquartile range (IQR) increase of $\mathrm{p}, \mathrm{p}^{\prime}-\mathrm{DDE}$ accounting for a $19 \%$ increase of TSH. Additional evidence of thyroid disruption was found in cord serum, with $\mathrm{p}^{\prime} \mathrm{p}-\mathrm{DDE}$ associated with increased bloodspot TSH and decreased TT3. Maternal $\beta-\mathrm{HCH}$ was associated with decreased FT3 and TT3 in cord blood, while cord $\beta-\mathrm{HCH}$ was associated with increased bloodspot TSH. In cord serum, $\mathrm{HCH}$ was negatively associated with TT4. Maternal chlordanes were negatively associated with both cord fT4 and TT4 levels, and chlordanes in cord serum were positively associated with TSH.

A study in Belgium $(n=198)$ reported that, in cord plasma, HCB was associated with decreased FT3 and FT4, and p, p'DDE with decreased FT4, however no significant variations were detected for TSH (79). In a study on infants born in a HCBpolluted area in Spain $(n=70)$, Ribas-Fitó et al. (73) focused on TSH for determination of thyroid status. While no relationship was found for $\mathrm{HCB}, \beta-\mathrm{HCH}$, and $\mathrm{p}, \mathrm{p}^{\prime}$-DDE were associated with higher TSH concentrations in plasma of neonates. Moreover, $\beta$ $\mathrm{HCH}$ tended to be negatively associated with TT3 $(P<0.065)$ and TT4 $(P<0.081)$ in placentas $(n=58)(83)$ and positively with TSH $(p=0.09)$ in cord serum $(n=453)$ (72).

Freire et al. (75), analyzed placenta samples $(n=220)$ from a male birth cohort in Spain and, out of 17 OCPs assessed, $\mathrm{p}, \mathrm{p}^{\prime} \mathrm{DDE}$ and HCB in placenta presented a close-to-significant positive $(p=0.09)$ or negative association $(p=0.09)$ with cord blood 
TABLE 1 | Parameters of epidemiological data retrieved in the review - Organochlorines.

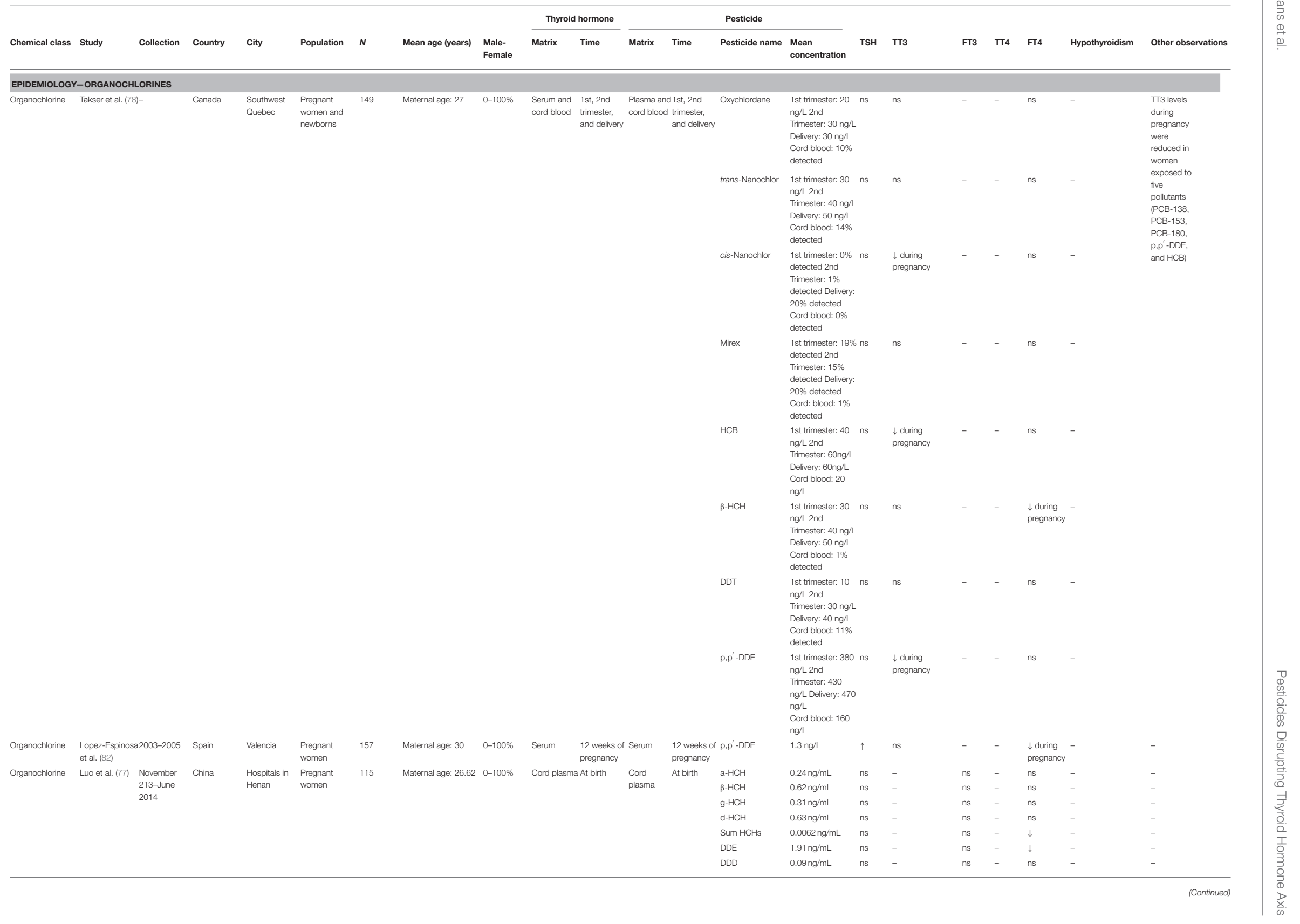




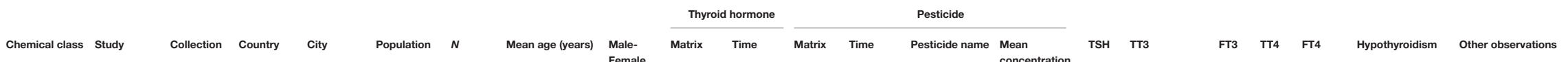

TT4 FT4 Hypothyroidism Other observations

\begin{tabular}{|c|c|c|c|c|c|c|c|c|c|c|c|c|c|c|c|c|c|c|c|}
\hline & & & & & & & & & & & & DDT & $4.89 \mathrm{ng} / \mathrm{mL}$ & ns & ns & - & ns & - & - \\
\hline & & & & & & & & & & & & Sum DDTs & $0.0201 \mathrm{ng} / \mathrm{mL}$ & $\uparrow$ & ns & - & ns & - & - \\
\hline & & & & & & & & & & & & Aldrin & $8.58 \mathrm{ng} / \mathrm{mL}$ & $\uparrow$ & ns & - & ns & - & - \\
\hline & & & & & & & & & & & & Dieldrin & $6.23 \mathrm{ng} / \mathrm{mL}$ & $\uparrow$ & ns & - & ns & - & - \\
\hline & & & & & & & & & & & & Endrin & $0.49 \mathrm{ng} / \mathrm{mL}$ & ns & ns & - & ns & - & - \\
\hline & & & & & & & & & & & & Sum Drins & $0.0412 \mathrm{ng} / \mathrm{mL}$ & $\uparrow$ & ns & - & ns & - & - \\
\hline & & & & & & & & & & & & Endosuffan I & $2.62 \mathrm{ng} / \mathrm{mL}$ & ns & ns & - & ns & - & - \\
\hline & & & & & & & & & & & & Endosulfan sulfate & $0.26 \mathrm{ng} / \mathrm{mL}$ & ns & ns & - & ns & - & - \\
\hline & & & & & & & & & & & & Sum endosulfan & $0.0071 \mathrm{ng} / \mathrm{mL}$ & ns & ns & - & ns & - & - \\
\hline & & & & & & & & & & & & Methoxychlor & $0.98 \mathrm{ng} / \mathrm{mL}$ & ns & ns & - & $\downarrow$ & - & - \\
\hline & & & & & & & & & & & & Heptachlor & $1.45 \mathrm{ng} / \mathrm{mL}$ & ns & ns & - & ns & & \\
\hline & & & & & & & & & & & & Sum OCPs & $0.0812 \mathrm{ng} / \mathrm{mL}$ & $\uparrow$ & ns & - & ns & - & - \\
\hline \multirow[t]{7}{*}{ Organochlorine } & \multirow{7}{*}{\multicolumn{2}{|c|}{$\begin{array}{l}\text { Asawasinsopon 2003-2004 } \\
\text { et al. (71) }\end{array}$}} & \multirow[t]{7}{*}{ Thailand } & \multirow{7}{*}{$\begin{array}{l}\text { Mae Rim } \\
\text { District of } \\
\text { Chiang Mai } \\
\text { Province }\end{array}$} & \multirow{7}{*}{$\begin{array}{l}\text { Pregnant } \\
\text { women and } \\
\text { newborns }\end{array}$} & \multirow[t]{7}{*}{39} & \multirow[t]{7}{*}{ Maternal age: 23.8} & \multirow{7}{*}{\multicolumn{2}{|c|}{ 46.2-53.8\% Cord serum }} & At delivery & \multirow{7}{*}{$\begin{array}{l}\text { Cord At delivery } \\
\text { serum }\end{array}$} & $\begin{array}{l}\mathrm{p}, \mathrm{p}^{\prime}-\mathrm{DDT} \\
\mathrm{p}, \mathrm{p}^{\prime}-\mathrm{DDE}\end{array}$ & $\begin{array}{l}77.7 \mathrm{ng} / \mathrm{g} \\
742 \mathrm{ng} / \mathrm{g}\end{array}$ & $\begin{array}{l}\text { ns } \\
\text { ns }\end{array}$ & $\overline{-}$ & $\downarrow$ & $\begin{array}{l}\text { ns } \\
\text { ns }\end{array}$ & - & - \\
\hline & & & & & & & & & & & & $\mathrm{p}, \mathrm{p}^{\prime}-\mathrm{DDD}$ & $89.1 \mathrm{ng} / \mathrm{g}$ & ns & - & ns & ns & - & \\
\hline & & & & & & & & & & & & o,p'-DDE & 46.6. $\mathrm{ng} / \mathrm{g}$ & ns & - & $\downarrow$ & ns & - & \\
\hline & & & & & & & & & & & & o,p'-DDT & $17.1 \mathrm{ng} / \mathrm{g}$ & ns & - & ns & ns & - & \\
\hline & & & & & & & & & & & & Dieldrin & $94.9 \mathrm{ng} / \mathrm{g}$ & ns & - & ns & ns & - & \\
\hline & & & & & & & & & & & & Heptachlor & $37.1 \mathrm{ng} / \mathrm{g}$ & ns & - & ns & ns & - & \\
\hline & & & & & & & & & & & & $\begin{array}{l}\text { Heptachlor } \\
\text { epoxide }\end{array}$ & $38.8 \mathrm{ng} / \mathrm{g}$ & ns & - & ns & ns & - & \\
\hline \multirow[t]{12}{*}{ POPs } & \multirow[t]{12}{*}{ Kim et al. (76) } & \multirow{12}{*}{$\begin{array}{l}\text { February and } \\
\text { December } \\
2011\end{array}$} & \multirow{12}{*}{ Korea } & \multirow{12}{*}{$\begin{array}{l}\text { Seoul, } \\
\text { Anyang, } \\
\text { Ansan, Jjiu }\end{array}$} & \multirow{12}{*}{$\begin{array}{l}\text { Pregnant } \\
\text { women and } \\
\text { newborns }\end{array}$} & \multirow[t]{12}{*}{148} & \multirow[t]{12}{*}{$\begin{array}{l}\text { Median maternal } \\
\text { age: } 33\end{array}$} & \multirow[t]{12}{*}{$0-100 \%$} & \multirow{12}{*}{$\begin{array}{l}\text { Umbilical } \\
\text { cord serum } \\
\text { + bloodspot } \\
\text { newborn }\end{array}$} & \multirow{12}{*}{$\begin{array}{l}\text { Delivery and } \\
2 \text { days after } \\
\text { t bith }\end{array}$} & \multirow{12}{*}{$\begin{array}{l}\text { d Cord blood Delivery } \\
\text { rand } \\
\text { maternal } \\
\text { serum }\end{array}$} & Sum HCHs & $\begin{array}{l}\text { Cord blood: } 10.4 \\
\text { ng/g }\end{array}$ & ns & ns & ns & ns & - & - \\
\hline & & & & & & & & & & & & Sum HCHs & $\begin{array}{l}\text { Maternal serum: } \\
9.4 \mathrm{ng} / \mathrm{g}\end{array}$ & ns & ns & ns & ns & - & - \\
\hline & & & & & & & & & & & & $\beta-\mathrm{HCH}$ & $\begin{array}{l}\text { Cord blood: } 7.5 \\
\text { ng/g }\end{array}$ & ns & ns & ns & ns & - & - \\
\hline & & & & & & & & & & & & $\beta-\mathrm{HCH}$ & $\begin{array}{l}\text { Maternal serum: } \\
7.5 \mathrm{ng} / \mathrm{g}\end{array}$ & ns & $\downarrow$ & ns & ns & - & - \\
\hline & & & & & & & & & & & & Sum CHDs & $\begin{array}{l}\text { Cord blood: } \\
\text { 2.6ng/g }\end{array}$ & $\uparrow$ & ns & ns & ns & - & - \\
\hline & & & & & & & & & & & & Sum CHDs & $\begin{array}{l}\text { Maternal } \\
\text { serum:3.9 ng/g }\end{array}$ & ns & ns & ns & $\downarrow$ & - & - \\
\hline & & & & & & & & & & & & Sum DDTs & $\begin{array}{l}\text { Cord blood: } 65.2 \\
\text { ng/g }\end{array}$ & ns & ns & ns & ns & - & - \\
\hline & & & & & & & & & & & & Sum DDTs & $\begin{array}{l}\text { Maternal serum: } \\
62.3 \mathrm{ng} / \mathrm{g}\end{array}$ & $\begin{array}{lr}\uparrow & n s \\
\text { bloodspot }\end{array}$ & $\begin{array}{l}\text { ns } \\
\text { pt }\end{array}$ & ns & ns & - & - \\
\hline & & & & & & & & & & & & $\mathrm{p}, \mathrm{p}^{\prime}-\mathrm{DDE}$ & $\begin{array}{l}\text { Cord blood: } 63 \\
\text { ng/g }\end{array}$ & $\begin{array}{ll}\uparrow & \text { ns } \\
\text { bloodspot }\end{array}$ & ns & ns & ns & - & - \\
\hline & & & & & & & & & & & & $p, p^{\prime}-D D E$ & $\begin{array}{l}\text { Maternal } \\
\text { serum:55.2 ng/g }\end{array}$ & $\begin{array}{l}\uparrow \\
\text { bloodspot }\end{array}$ & ns & ns & ns & - & - \\
\hline & & & & & & & & & & & & $\mathrm{HCB}$ & $\begin{array}{l}\text { Cord blood: } 12.7 .0 \\
\text { ng/g }\end{array}$ & Ons & ns & $\downarrow$ & ns & - & - \\
\hline & & & & & & & & & & & & HCB & $\begin{array}{l}\text { Maternal serum: } \\
5.5 \mathrm{ng} / \mathrm{g}\end{array}$ & ns & ns & ns & ns & - & - \\
\hline Organochlorine & $\begin{array}{l}\text { Maervoet et al. } \\
\text { (79) }\end{array}$ & 2002-2004 & Belgium & Flanders & $\begin{array}{l}\text { Pregnant } \\
\text { women }\end{array}$ & 198 & Maternal age: 29.4 & $0-100 \%$ & $\begin{array}{l}\text { Cord } \\
\text { blood }\end{array}$ & Delivery & Cord blood Delivery & $\begin{array}{l}\mathrm{p}, \mathrm{p}^{\prime}-\mathrm{DDE} \\
\mathrm{HCB}\end{array}$ & $\begin{array}{l}0.37 \mathrm{ng} / \mathrm{mL} \\
0.05 \mathrm{ng} / \mathrm{mL}\end{array}$ & $\begin{array}{l}\text { ns } \\
\text { ns }\end{array}$ & $\begin{array}{l}\text { ns } \\
\downarrow\end{array}$ & - & $\downarrow$ & - & - \\
\hline Organochlorine & $\begin{array}{l}\text { Ribas-Fitó et al. } \\
\text { (73) }\end{array}$ & . 1997-1999 & Spain & Flix (catalonia) & Newborns & 70 & Not reported & Not reporte & d Plasma & $\begin{array}{l}3 \text { days after } \\
\text { birth }\end{array}$ & $\begin{array}{l}\text { Cord Delivery } \\
\text { serum }\end{array}$ & $\begin{array}{l}p, p^{\prime}-D D E \\
H C B\end{array}$ & $\begin{array}{l}\text { Not reported } \\
\text { Not reported }\end{array}$ & $\stackrel{\uparrow}{n s}$ & - & - & - & - & - \\
\hline & & & & & & & & & & & & $\beta-\mathrm{HCH}$ & Not reported & $\uparrow$ & - & - & - & - & - \\
\hline
\end{tabular}


TABLE 1 | Continued

\begin{tabular}{|c|c|c|c|c|c|c|c|c|c|c|c|c|c|c|c|c|c|c|c|c|c|}
\hline \multirow[b]{2}{*}{ Chemical class } & \multirow[b]{2}{*}{ Study } & \multirow[b]{2}{*}{ Collection } & \multirow[b]{2}{*}{ Country } & \multirow[b]{2}{*}{ city } & \multirow[b]{2}{*}{ Population } & \multirow[b]{2}{*}{$N$} & \multirow[b]{2}{*}{ Mean age (years) } & \multirow[b]{2}{*}{$\begin{array}{l}\text { Male- } \\
\text { Female }\end{array}$} & \multicolumn{2}{|c|}{ Thyroid hormone } & \multicolumn{4}{|c|}{ Pesticide } & \multirow[b]{2}{*}{ TSH } & \multirow[b]{2}{*}{ тт3 } & \multirow[b]{2}{*}{ FT3 } & \multirow[b]{2}{*}{$\mathrm{TT4}$} & \multirow[b]{2}{*}{$\mathrm{FT4}$} & \multirow[b]{2}{*}{ Hypothyroidism } & \multirow[b]{2}{*}{ Other observations } \\
\hline & & & & & & & & & Matrix & Time & Matrix & Time & Pesticide name & $\begin{array}{l}\text { Mean } \\
\text { concentration }\end{array}$ & & & & & & & \\
\hline Organochlorine & Liet al. (83) & $1997-2001$ & Denmark & Copenhagen & $\begin{array}{l}\text { Placenta } \\
\text { samples }\end{array}$ & 58 & Maternal age: 30.4 & $\begin{array}{l}\begin{array}{l}100 \% \\
\text { placenta's of } \\
\text { boys }\end{array}\end{array}$ & Placenta & Delivery & Placenta & Delivery & $\begin{array}{l}\text { Sum } 25 \text { OCPs } \\
\beta \text {-HCH } \\
\text { methoxychlor }\end{array}$ & $\begin{array}{l}77.7 \mathrm{ng} / \mathrm{g} \\
9.18 \mathrm{ng} / \mathrm{g} / \mathrm{g} \\
0.008 \mathrm{ng} / \mathrm{g}\end{array}$ & $\begin{array}{l}- \\
- \\
-\end{array}$ & $\begin{array}{l}\mathrm{ns} \\
\downarrow p<0.081 \\
\mathrm{~ns}\end{array}$ & $\begin{array}{l}- \\
\overline{-}\end{array}$ & $\begin{array}{l}\mathrm{ns} \\
\downarrow p< \\
\downarrow 0.065 \\
\mathrm{~ns}\end{array}$ & $\begin{array}{l}- \\
- \\
-\end{array}$ & $\begin{array}{l}- \\
-\end{array}$ & $\begin{array}{l}\text { Additionally } \\
\text { measured } \\
\text { rT3: } \\
\text { methoxychlor } \\
\text { were } \\
\text { inversely } \\
\text { associated } \\
\text { with rT3 }\end{array}$ \\
\hline Organochlorine & $\begin{array}{l}\text { Lopez- } \\
\text { Espinosa et al. } \\
\text { (72) }\end{array}$ & 2004-2006 & Spain & Valencia & $\begin{array}{l}\text { Pregnant } \\
\text { women and } \\
\text { newborns }\end{array}$ & 453 & 30 & $54.7-45.3 \%$ & $\begin{array}{l}\text { Dry blood } \\
\text { spot }\end{array}$ & $\begin{array}{l}3 \text { days after } \\
\text { birth }\end{array}$ & $\begin{array}{l}\text { Cord } \\
\text { serum }\end{array}$ & Delivery & $\begin{array}{l}\text { p,p'-DDT } \\
\text { p,p'-DDE } \\
\mathrm{HCB} \\
\beta-\mathrm{HCH}\end{array}$ & $\begin{array}{l}8.0 \mathrm{ng} / \mathrm{g} \\
197 \mathrm{ng} / \mathrm{g} \\
75 \mathrm{ng} / \mathrm{g} \\
20 \mathrm{ng} / \mathrm{g}\end{array}$ & $\begin{array}{l}\text { ns } \\
\text { ns } \\
\text { ns } \\
\uparrow p= \\
0.09\end{array}$ & $\begin{array}{l}- \\
- \\
- \\
-\end{array}$ & $\begin{array}{l}- \\
- \\
- \\
-\end{array}$ & $\begin{array}{l}- \\
- \\
- \\
-\end{array}$ & $\begin{array}{l}- \\
- \\
- \\
-\end{array}$ & $\begin{array}{l}- \\
- \\
- \\
-\end{array}$ & $\begin{array}{l}- \\
- \\
- \\
-\end{array}$ \\
\hline Organochlorine & $\begin{array}{l}\text { Freire } \\
\text { et al. }(75)\end{array}$ & 2000-2002 & Spain & $\begin{array}{l}\text { Southern } \\
\text { spain }\end{array}$ & $\begin{array}{l}\text { Pregnant } \\
\text { women and } \\
\text { neonates }\end{array}$ & 220 & Maternal age: 31.8 & $100-0 \%$ & Cord blood & Delivery & Placenta & Delivery & $\begin{array}{l}o, p,-D D T \\
p, p-D T \\
p, p^{\prime}-D D E\end{array}$ & $\begin{array}{l}0.86 \mathrm{ng} / \mathrm{g} \\
1.25 \mathrm{ng} / \mathrm{g} \\
2.01 \mathrm{ng} / \mathrm{g}\end{array}$ & $\begin{array}{l}\text { ns } \\
\text { ns } \\
\uparrow p= \\
0.09\end{array}$ & $\begin{array}{l}- \\
-\end{array}$ & $\begin{array}{l}- \\
-\end{array}$ & $\begin{array}{l}- \\
-\end{array}$ & $\begin{array}{l}\overline{-} \\
-\end{array}$ & $\overline{-}$ & - \\
\hline & & & & & & & & & & & & & o,p'-DDD & $1.91 \mathrm{ng} / \mathrm{g}$ & ns & - & - & - & - & - & \\
\hline & & & & & & & & & & & & & Sum DDTs & $4.16 \mathrm{ng} / \mathrm{g}$ & ns & - & - & - & - & - & \\
\hline & & & & & & & & & & & & & $\begin{array}{l}\text { Endosulfan-I } \\
\text { Endosulfan-\|l }\end{array}$ & $\begin{array}{l}0.73 \mathrm{ng} / \mathrm{g} \\
1.37 \mathrm{ng} / \mathrm{g}\end{array}$ & ns & - & - & - & - & - & \\
\hline & & & & & & & & & & & & & $\begin{array}{l}\text { Endosulfan-II } \\
\text { Endosulfan-diol }\end{array}$ & $\begin{array}{l}1.37 \mathrm{ng} / \mathrm{g} \\
2.10 \mathrm{ng} / \mathrm{g}\end{array}$ & ns & - & - & - & - & - & \\
\hline & & & & & & & & & & & & & Endosuffan-ether & $0.23 \mathrm{ng} / \mathrm{g}$ & ns & - & - & - & - & - & \\
\hline & & & & & & & & & & & & & Endosulfan-sulfate & $0.93 \mathrm{ng} / \mathrm{g}$ & $\downarrow$ & - & - & - & - & & \\
\hline & & & & & & & & & & & & & $\begin{array}{l}\text { Endosulfan- } \\
\text { lactone }\end{array}$ & $1.14 \mathrm{ng} / \mathrm{g}$ & ns & - & - & - & - & & \\
\hline & & & & & & & & & & & & & Sum Endosulfans & $4.02 \mathrm{ng} / \mathrm{g}$ & ns & - & - & - & - & - & \\
\hline & & & & & & & & & & & & & Aldrin & $0.82 \mathrm{ng} / \mathrm{g}$ & ns & - & - & - & - & - & \\
\hline & & & & & & & & & & & & & Endrin & $2.53 \mathrm{ng} / \mathrm{g}$ & $\begin{array}{l}\uparrow \\
\text { ns }\end{array}$ & - & - & - & - & - & \\
\hline & & & & & & & & & & & & & $\begin{array}{l}\text { Dieldrin } \\
\text { Lindane }\end{array}$ & $\begin{array}{l}1.05 \mathrm{ng} / \mathrm{g} \\
0.41 \mathrm{ng} / \mathrm{g}\end{array}$ & ns & - & - & - & - & - & \\
\hline & & & & & & & & & & & & & $\mathrm{HCB}$ & $1.02 \mathrm{ng} / \mathrm{g}$ & $\begin{array}{l}\downarrow p= \\
0.09\end{array}$ & - & - & - & - & & \\
\hline & & & & & & & & & & & & & Methoxychlor & $1.20 \mathrm{ng} / \mathrm{g}$ & ns & - & - & - & - & - & \\
\hline & & & & & & & & & & & & & Mirex & $1.15 \mathrm{ng} / \mathrm{g}$ & ns & - & - & - & - & - & \\
\hline Organochlorine & $\begin{array}{l}\text { Dufour et al. } \\
\text { (81) }\end{array}$ & 2013-2016 & Belgium & Liege & $\begin{array}{l}\text { Pregnant } \\
\text { women and }\end{array}$ & 221 & 29.2 & $52.8-47.2 \%$ & $\begin{array}{l}\text { Dry blood } \\
\text { spot }\end{array}$ & $\begin{array}{l}3 \text { days after } \\
\text { birth }\end{array}$ & $\begin{array}{l}\text { Cord } \\
\text { serum }\end{array}$ & Delivery & $\begin{array}{l}\mathrm{HCB} \\
\beta-\mathrm{HCH}\end{array}$ & $\begin{array}{l}0.0 \% \text { detected } \\
0.5 \% \text { detected }\end{array}$ & - & - & $\overline{-}$ & - & $\overline{-}$ & $\overline{-}$ & - \\
\hline & & & & & newborns & & & & & & & & Trans-Nanochlor & $0.0 \%$ detected & - & - & - & - & - & - & \\
\hline & & & & & & & & & & & & & $\mathrm{p}, \mathrm{p}^{\prime}-\mathrm{DDE}$ & 24.1\% detected & Boys: & - & - & - & - & ns & \\
\hline Organochlorine & $\begin{array}{l}\text { Dallaire et al. } \\
(74)\end{array}$ & 1993-1996 & Canada & $\begin{array}{l}\text { Nunavik } r \\
\text { (Quebec) }\end{array}$ & $\begin{array}{l}\text { Pregnant } \\
\text { women and } \\
\text { neonates }\end{array}$ & 410 & Maternal age: 23 & $48.1-51.9 \%$ & Cord serum & Delivery & $\begin{array}{l}\text { Cord } \\
\text { plasma }\end{array}$ & Delivery & HCB & $140 \mathrm{ng} / \mathrm{L}$ & ns & ns & - & - & $\uparrow$ & - & - \\
\hline & & 1993-1997 & Canada & $\begin{array}{l}\text { Lower North } \\
\text { Shore of the } \\
\text { St. Lawarence } \\
\text { River (Quebed }\end{array}$ & $\begin{array}{l}\text { Pregnant } \\
\text { women and } \\
\text { neonates } \\
\text { c) }\end{array}$ & 260 & Maternal age: 25 & $48.5-51.5 \%$ & Cord serum & Delivery & $\begin{array}{l}\text { Cold } \\
\text { plasma }\end{array}$ & Delivery & $\mathrm{HCB}$ & $150 \mathrm{ng} / \mathrm{L}$ & ns & ns & - & - & $\uparrow$ & - & \\
\hline
\end{tabular}




\begin{tabular}{|c|c|c|c|c|c|c|c|c|c|c|c|c|c|c|c|c|c|c|c|c|c|}
\hline \multirow[b]{2}{*}{ Chemical class } & \multirow[b]{2}{*}{ Study } & \multirow[b]{2}{*}{ Collection } & \multirow[b]{2}{*}{ Country } & \multirow[b]{2}{*}{ City } & \multirow[b]{2}{*}{ Population } & \multirow[b]{2}{*}{$N$} & \multirow[b]{2}{*}{ Mean age (years) } & \multirow[b]{2}{*}{$\begin{array}{l}\text { Male- } \\
\text { Female }\end{array}$} & \multicolumn{2}{|c|}{ Thyroid hormone } & \multicolumn{4}{|c|}{ Pesticide } & \multirow[b]{2}{*}{ TSH } & \multirow[b]{2}{*}{ ттз } & \multirow[b]{2}{*}{ FT3 } & \multirow[b]{2}{*}{ TT4 } & \multirow[b]{2}{*}{ FT4 } & \multirow[b]{2}{*}{ Hypothyroidism } & \multirow[b]{2}{*}{ Other observations } \\
\hline & & & & & & & & & Matrix & Time & Matrix & Time & Pesticide name & $\begin{array}{l}\text { Mean } \\
\text { concentration }\end{array}$ & & & & & & & \\
\hline \multirow[t]{4}{*}{ Organochlorine } & $\begin{array}{l}\text { Cordier et al. } \\
\text { (80) }\end{array}$ & 2004-2007 & Guadeloupe & $\begin{array}{l}\text { University } \\
\text { Hospital } \\
\text { Pointe-a-dititre }\end{array}$ & $\begin{array}{l}\text { Mother-child } \\
\text { cohort }\end{array}$ & 111 & Maternal age: 30.7 & $0-100 \%$ & Child serum & $\begin{array}{l}\text { At } 3 \text { months } \\
\text { of age }\end{array}$ & $\begin{array}{l}\text { Cord } \\
\text { blood and } \\
\text { breast milk }\end{array}$ & $\begin{array}{l}\text { Cord blood: } \\
\text { at delivery- } \\
\text { k breast milk: }\end{array}$ & Chlordecone & $\begin{array}{l}\text { Median-cord } \\
\text { blood: } 0.14 \mu g / L\end{array}$ & Boys: $\uparrow$. & - & ns & - & Boys: ns & - & - \\
\hline & & & & $\begin{array}{l}\text { and the } \\
\text { General }\end{array}$ & & & & & & & & $\begin{array}{l}3 \text { months } \\
\text { ater delvery }\end{array}$ & & & ns & - & ns & - & Girls: ns & - & - \\
\hline & & & & Hospitials of & & & & & & & & & & Breast milk & ns & - & Boys: & - & Boys: ns & - & - \\
\hline & & & & Basse-Terre & & & & & & & & & & & ns & - & Girls: $\downarrow$ & - & Girls: $\downarrow$ & - & - \\
\hline \multirow[t]{4}{*}{ Organochlorine } & $\begin{array}{l}\text { Alvarez- } \\
\text { Pedrerol et al. }\end{array}$ & 1997-1999 & Spain & $\begin{array}{l}\text { Island of } \\
\text { Menorca }\end{array}$ & Children & 259 & Maternal age: 33 & $47.9-52.1 \%$ & Serum & $\begin{array}{l}\text { At } 4 \text { years of } \\
\text { age }\end{array}$ & f Serum & $\begin{array}{l}\text { At } 4 \text { years } \\
\text { of age }\end{array}$ & $\mathrm{p}, \mathrm{p}^{\prime}-\mathrm{DDT}$ & $0.06 \mathrm{ng} / \mathrm{mL}$ & ns & $\downarrow$ & - & - & ns & - & - \\
\hline & & & & & & & & & & & & & p,p'-DDE & $0.88 \mathrm{ng} / \mathrm{mL}$ & ns & ns & - & - & ns & - & \\
\hline & & & & & & & & & & & & & HCB & $0.32 \mathrm{ng} / \mathrm{mL}$ & ns & ns & - & - & ns & - & \\
\hline & & & & & & & & & & & & & $\beta-\mathrm{HCH}$ & $0.22 \mathrm{ng} / \mathrm{mL}$ & ns & $\downarrow$ & - & - & ns & - & \\
\hline Organochlorine & $\begin{array}{l}\text { Meeker et al. } \\
\text { (84) }\end{array}$ & $\begin{array}{l}\text { January } 2000 \\
\text { and May } \\
2003\end{array}$ & $\begin{array}{l}\text { North- } \\
\text { America }\end{array}$ & Boston & Men & 341 & 36 & $100-0 \%$ & Serum & $\begin{array}{l}\text { Cross- } \\
\text { sectional }\end{array}$ & Serum & $\begin{array}{l}\text { Cross- } \\
\text { sectional }\end{array}$ & $\begin{array}{l}\text { p,p'-DDE } \\
\text { HCB }\end{array}$ & $\begin{array}{l}236 \mathrm{ng} / \mathrm{g} \\
15.6 \mathrm{ng} / \mathrm{g}\end{array}$ & $\downarrow$ & $\uparrow$ & $\begin{array}{l}- \\
-\end{array}$ & $\begin{array}{l}- \\
-\end{array}$ & $\uparrow$ & - & $\begin{array}{l}- \\
-\end{array}$ \\
\hline Organochlorine & $\begin{array}{l}\text { Bloom } \\
\text { et al. (85) }\end{array}$ & 2000-2002 & $\begin{array}{l}\text { Noth- } \\
\text { America }\end{array}$ & $\begin{array}{l}\text { Upper } \\
\text { Hudson river } \\
\text { communities }\end{array}$ & Women & 48 & 63.2 & $0-100 \%$ & Serum & $\begin{array}{l}\text { Cross- } \\
\text { sectional }\end{array}$ & Serum & $\begin{array}{l}\text { Cross- } \\
\text { sectional }\end{array}$ & Sum DDT & $3.59 \mu \mathrm{g} / \mathrm{L}$ & ns & $\uparrow$ & - & $\uparrow$ & ns & - & - \\
\hline Organochlorine & $\begin{array}{l}\text { Blanco-Munoz } \\
\text { et al. (86) }\end{array}$ & $\begin{array}{l}\text { July-October } \\
2004 \text { and } \\
\text { December } \\
2004-\text { May } \\
2005\end{array}$ & Mexico & $\begin{array}{l}\text { States of } \\
\text { Mexico and } \\
\text { Morelos }\end{array}$ & $\begin{array}{l}\text { Floriculture } \\
\text { workers (men) }\end{array}$ & 136 & 32.7 & $100-0 \%$ & Serum & Longitudinal & $\begin{array}{l}\text { DDE an } \\
\text { DDT in } \\
\text { serum and } \\
\text { DAP } \\
\text { metabolites } \\
\text { in urine }\end{array}$ & $\begin{array}{l}\text { Longitudinal } \\
\text { study } \\
\text { s }\end{array}$ & DDE & $\begin{array}{l}6.14 \text { and } \\
4.71 \mathrm{ng} / \mathrm{ml} \text { in rainy } \\
\text { and dry seasons }\end{array}$ & ns & $\uparrow$ & - & $\uparrow$ & - & - & - \\
\hline \multirow[t]{5}{*}{ Organochlorine } & $\begin{array}{l}\text { Rathore et al. } \\
\text { (87) }\end{array}$ & 1997-1998 & India & Jaipur & $\begin{array}{l}\text { Women visiting } \\
\text { the Thyroid } \\
\text { Clinic }\end{array}$ & & 37 & $0-100 \%$ & Serum & $\begin{array}{l}\text { Cross- } \\
\text { sectional }\end{array}$ & Serum & $\begin{array}{l}\text { Cross- } \\
\text { sectional }\end{array}$ & Sum OC & $\begin{array}{l}18.83 \text { ppm } \\
\text { depleted T4 vs. } \\
14.68 \text { normal T4 }\end{array}$ & ns & ns & - & ns & - & ns & - \\
\hline & & & & & & & & & & & & & $\begin{array}{l}\text { Total DDT } \\
\text { (pp'DDE+pp' } \\
\text { DDT+pp'DDD) }\end{array}$ & $\begin{array}{l}8.43 \text { ppm depleted } \\
\text { T3 vs. } 6.91 \text { normal } \\
\text { T4 }\end{array}$ & dns & ns & - & ns & - & ns & \\
\hline & & & & & & & & & & & & & Total $H C H(\alpha, \beta, ?)$ & $\begin{array}{l}3.82 \text { ppm depleted } \\
\text { T4 vs. } 3.86 \text { normal } \\
\text { t4 } 4\end{array}$ & dns & ns & - & ns & - & ns & \\
\hline & & & & & & & & & & & & & Dieldrin & $\begin{array}{l}5.38 \mathrm{ppm} \mathrm{in} \\
\text { depleted T4 group } \\
\text { vs. } 2.5 \text { normal T4 }\end{array}$ & ns & ns & - & $\downarrow$ & - & $\uparrow$ & \\
\hline & & & & & & & & & & & & & Hepatchlor & $\begin{array}{l}1.18 \mathrm{ppm} \text { in } \\
\text { depleted T4 vs. } \\
1.41 \text { normal T4 }\end{array}$ & ns & ns & - & ns & - & ns & \\
\hline Organochlorine & $\begin{array}{l}\text { Rylander et al. } \\
\text { (88) }\end{array}$ & $\begin{array}{l}\text { Not clearly } \\
\text { indicated }\end{array}$ & Sweden & $\begin{array}{l}\text { Swedish east } \\
\text { coast, off the } \\
\text { Baltic Sea }\end{array}$ & Fishermen & 196 & 59 & $100-0 \%$ & Serum & $\begin{array}{l}\text { Cross- } \\
\text { sectional }\end{array}$ & Serum & $\begin{array}{l}\text { Cross- } \\
\text { sectional }\end{array}$ & $p^{\prime} p^{\prime}-D D E$ & $580 \mathrm{ng} / \mathrm{g}$ lipid & $\uparrow$ & - & - & - & ns & - & $\begin{array}{l}\text { Also } \\
\text { measured } \\
\text { FSH,LH, } \\
\text { estradiol, } \\
\text { and } \\
\text { testostosterone } \\
\text { Negative } \\
\text { association: } \\
\text { p,p'-DEE } \\
\text { and } \\
\text { estradiol } \\
\text { level. }\end{array}$ \\
\hline
\end{tabular}


TABLE 1 | Continued

\begin{tabular}{|c|c|c|c|c|c|c|c|c|c|c|c|c|c|c|c|c|c|c|c|c|c|}
\hline \multirow[b]{2}{*}{ Chemical class } & \multirow[b]{2}{*}{ Study } & \multirow[b]{2}{*}{ Collection } & \multirow[b]{2}{*}{ Country } & \multirow[b]{2}{*}{ City } & \multirow[b]{2}{*}{ Population } & \multirow[b]{2}{*}{$N$} & \multirow[b]{2}{*}{ Mean age (years) } & \multirow[b]{2}{*}{$\begin{array}{l}\text { Male- } \\
\text { Female }\end{array}$} & \multicolumn{2}{|c|}{ Thyroid hormone } & \multicolumn{4}{|c|}{ Pesticide } & \multirow[b]{2}{*}{ TSH } & \multirow[b]{2}{*}{ ттз } & \multirow[b]{2}{*}{ FT3 } & \multirow[b]{2}{*}{ TT4 } & \multirow[b]{2}{*}{ FT4 } & \multirow[b]{2}{*}{ Hypothyroidism } & \multirow[b]{2}{*}{ Other observations } \\
\hline & & & & & & & & & Matrix & Time & Matrix & Time & Pesticide name & $\begin{array}{l}\text { Mean } \\
\text { concentration }\end{array}$ & & & & & & & \\
\hline Organochlorine & $\begin{array}{l}\text { Schell } \\
\text { et al. (89) }\end{array}$ & 1995-2000 & $\begin{array}{l}\text { North } \\
\text { America }\end{array}$ & $\begin{array}{l}\text { St. Lawrence } \\
\text { River with } \\
\text { territory in } \\
\text { New York } \\
\text { Statess in } \\
\text { Ontario and } \\
\text { Quebec }\end{array}$ & $\begin{array}{l}\text { Mother-youth } \\
\text { pairs }\end{array}$ & 232 & Youth: 17.6 & - & Serum & $\begin{array}{l}\text { Cross- } \\
\text { sectional }\end{array}$ & Serum & $\begin{array}{l}\text { Cross- } \\
\text { sectional }\end{array}$ & $p-p^{\prime}-D D E$ & $\begin{array}{l}\text { Non-breast fed: } \\
0.03 \text { ppb } \\
\text { breast-fed: } 0.04 \\
\\
\text { Non-breast fed: } \\
0.31 \text { ppb } \\
\text { breast-fed: } 0.41\end{array}$ & ns & ns & - & - & $\downarrow$ & - & $\begin{array}{l}\text { Breast-fed } \\
\text { adolescents } \\
\text { had higher } \\
\text { level of } \\
\text { p.p.'-DDE }\end{array}$ \\
\hline Organochlorine & $\begin{array}{l}\text { Goldner et al. } \\
(48)\end{array}$ & $\begin{array}{l}\text { 1993-1997 } \\
\text { (Phase 1), } \\
\text { 1999-2003 } \\
\text { (Phase 2) }\end{array}$ & $\begin{array}{l}\text { North } \\
\text { America }\end{array}$ & $\begin{array}{l}\text { Canadalarth } \\
\text { lowa, North } \\
\text { Carolina }\end{array}$ & $\begin{array}{l}\text { Female } \\
\text { spouses of } \\
\text { workers } \\
\text { involved in } \\
\text { Agricultural } \\
\text { Health Study }\end{array}$ & 16,529 & 47.2+HH109:L118 & $0-100 \%$ & $\begin{array}{l}\text { Self- } \\
\text { reported } \\
\text { thyroid } \\
\text { disease }\end{array}$ & $\begin{array}{l}\text { Self- } \\
\text { reported } \\
\text { thyroid } \\
\text { disease }\end{array}$ & $\begin{array}{l}\text { Detalied } \\
\text { sef- } \\
\text { reported } \\
\text { use of } \\
\text { pesticides. }\end{array}$ & $\begin{array}{l}\text { Detailed } \\
\text { self-reported } \\
\text { use of } \\
\text { pesticides. }\end{array}$ & $\begin{array}{l}\text { Aldrin } \\
\text { CChlordane } \\
\text { DDT } \\
\text { Heptachlor } \\
\text { Lindane }\end{array}$ & $\begin{array}{l}- \\
- \\
- \\
-\end{array}$ & $\begin{array}{l}- \\
- \\
- \\
-\end{array}$ & $\begin{array}{l}- \\
- \\
- \\
-\end{array}$ & $\begin{array}{l}- \\
- \\
- \\
- \\
-\end{array}$ & $\begin{array}{l}- \\
- \\
- \\
-\end{array}$ & $\begin{array}{l}- \\
- \\
- \\
-\end{array}$ & $\begin{array}{l}\uparrow \\
\uparrow \\
\uparrow \\
\uparrow \\
\uparrow\end{array}$ & $\begin{array}{l}- \\
- \\
- \\
- \\
-\end{array}$ \\
\hline Organochlorine & Lerro et al. (92) & $\begin{array}{l}\text { June 2010- } \\
\text { September } \\
2013\end{array}$ & $\begin{array}{l}\text { North- } \\
\text { America }\end{array}$ & $\begin{array}{l}\text { lowa or North } \\
\text { Carolina }\end{array}$ & $\begin{array}{l}\text { Pesticicide } \\
\text { applicators }\end{array}$ & 679 & Not indicated & $100-0 \%$ & Serum & $\begin{array}{l}\text { Cross- } \\
\text { sectional }\end{array}$ & $\begin{array}{l}\text { Detalied } \\
\text { self- } \\
\text { reported } \\
\text { use of }\end{array}$ & $\begin{array}{l}\text { Detalied } \\
\text { self-erported } \\
\text { use of } \\
\text { pesticides. }\end{array}$ & $\begin{array}{l}\text { Aldrin } \\
\text { Chlordane } \\
\text { DDT } \\
\text { Heptachlor }\end{array}$ & $\begin{array}{l}- \\
- \\
-\end{array}$ & $\begin{array}{l}\begin{array}{c}1 \\
\text { ns } \\
\text { ns } \\
\text { ns }\end{array} \\
\end{array}$ & $\begin{array}{l}\text { ns } \\
\text { ns } \\
\text { ns } \\
\text { ns }\end{array}$ & $\begin{array}{l}- \\
- \\
- \\
-\end{array}$ & $\begin{array}{l}\downarrow \\
\text { ns } \\
\text { ns } \\
\text { ns }\end{array}$ & $\begin{array}{l}- \\
- \\
-\end{array}$ & $\begin{array}{l}\uparrow \\
\text { ns } \\
\text { ns } \\
\text { ns }\end{array}$ & $\begin{array}{l}- \\
- \\
-\end{array}$ \\
\hline Organochlorine & $\begin{array}{l}\text { Piccoli } \\
\text { et al. (90) }\end{array}$ & 2012-2013 & Brazil & $\begin{array}{l}\text { Farroupiliha, } \\
\text { Serra gaucha, } \\
\text { South Brazil }\end{array}$ & $\begin{array}{l}\text { Agricultural } \\
\text { workers }\end{array}$ & 275 & 42 & $56.4-43.6 \%$ & Serum & $\begin{array}{l}\text { Cross- } \\
\text { sectional }\end{array}$ & $\begin{array}{l}\text { Destidides. } \\
\text { Serum }\end{array}$ & $\begin{array}{l}\text { Cross- } \\
\text { sectional }\end{array}$ & $\begin{array}{l}\text { HCH, HCB, } \\
\text { heptachlor } \\
\text { epoxide A, } \\
\text { heptachlor } \\
\text { epoxide B, } \\
\text { heptachlor, } \\
\text { transnonachlor, } \\
\text { DDT, DDE, DDD, } \\
\text { p,p'-DDD, } \\
\text { endosulfan, I, } \\
\text { endosulfan II, } \\
\text { aldrin, endrin, } \\
\text { dieldrin, } \\
\text { methoxychlor, } \\
\text { mirex, } \\
\text { pentachloroanisole }\end{array}$ & $\begin{array}{l}\text { Many subject were } \\
\text { below limit of } \\
\text { detection, } \\
\text { therefore no mean }\end{array}$ & & $\uparrow$ & - & - & $\uparrow$ & - & - \\
\hline \multirow[t]{4}{*}{ Organochlorine } & $\begin{array}{l}\text { Shrestha et al. } \\
\text { (91) }\end{array}$ & 1991-1997 & $\begin{array}{l}\text { North- } \\
\text { America }\end{array}$ & $\begin{array}{l}\text { North } \\
\text { Caroline and }\end{array}$ & $\begin{array}{l}\text { Pesticide } \\
\text { applicators }\end{array}$ & 35,150 & Median age 62 & $97.9-2.1 \%$ & $\begin{array}{l}\text { Self- } \\
\text { reported }\end{array}$ & $\begin{array}{l}\text { Self- } \\
\text { reported }\end{array}$ & $\begin{array}{l}\text { Detalied } \\
\text { seff- }\end{array}$ & $\begin{array}{l}\text { Detailed } \\
\text { self- }\end{array}$ & Aldrin & Aldrin & $\mathrm{nm}$ & $\mathrm{nm}$ & $\mathrm{nm}$ & $\mathrm{nm}$ & $\mathrm{nm}$ & $\begin{array}{l}\uparrow(\text { attained } \\
\text { age) }\end{array}$ & $\mathrm{nm}$ \\
\hline & & & & & & & & & $\begin{array}{l}\text { thyroid } \\
\text { disease }\end{array}$ & $\begin{array}{l}\text { thyroid } \\
\text { disease }\end{array}$ & $\begin{array}{l}\text { reported } \\
\text { us of }\end{array}$ & $\begin{array}{l}\text { reported us } \\
\text { of pesticides }\end{array}$ & Heptachlor & Heptachlor & $\mathrm{nm}$ & $\mathrm{nm}$ & $\mathrm{nm}$ & $\mathrm{nm}$ & $\mathrm{nm}$ & $\begin{array}{l}\uparrow(\text { attained } \\
\text { age) }\end{array}$ & $\mathrm{nm}$ \\
\hline & & & & & & & & & & & pesticides & & Lindane & Lindane & $\mathrm{nm}$ & $\mathrm{nm}$ & $\mathrm{nm}$ & $\mathrm{nm}$ & $\mathrm{nm}$ & $\begin{array}{l}\uparrow \text { (attained } \\
\text { age) }\end{array}$ & $\mathrm{nm}$ \\
\hline & & & & & & & & & & & & & Chlordane & Chlordane & $\mathrm{nm}$ & $\mathrm{nm}$ & $\mathrm{nm}$ & $\mathrm{nm}$ & $\mathrm{nm}$ & $\begin{array}{l}\uparrow \text { (all } \\
\text { participants) }\end{array}$ & $\mathrm{nm}$ \\
\hline \multirow[t]{4}{*}{ Organochlorine } & $\begin{array}{l}\text { Goldner et al. } \\
(49)\end{array}$ & $\begin{array}{l}\text { 1993-1997 } \\
\text { (Phase 1). }\end{array}$ & $\begin{array}{l}\text { North } \\
\text { America }\end{array}$ & $\begin{array}{l}\text { lowa, North } \\
\text { Carolina }\end{array}$ & $\begin{array}{l}\text { Male private } \\
\text { applicators }\end{array}$ & 22,246 & 45.6 & $100-0 \%$ & $\begin{array}{l}\text { Self- } \\
\text { reported }\end{array}$ & $\begin{array}{l}\text { Self- } \\
\text { reported }\end{array}$ & $\begin{array}{l}\text { Detalied } \\
\text { sef-e }\end{array}$ & $\begin{array}{l}\text { Detailed } \\
\text { self-e }\end{array}$ & $\begin{array}{l}\text { Chlordane } \\
\text { DDT }\end{array}$ & $\overline{-}$ & - & - & $\overline{-}$ & - & $\overline{-}$ & $\uparrow$ & $\overline{-}$ \\
\hline & & 1999-2003 & & & (mainly farmers) & & & & thyroid & thyroid & reported & reported & Heptachlor & - & - & - & - & - & - & $\uparrow$ & - \\
\hline & & (Phase 2) & & & in AHS & & & & disease & disease & $\begin{array}{l}\text { use of } \\
\text { pestides }\end{array}$ & $\begin{array}{l}\text { use of } \\
\text { pestidides }\end{array}$ & Lindane & - & - & - & - & - & - & $\uparrow$ & - \\
\hline & & & & & & & & & & & & & Toxaphene & - & - & - & - & - & - & $\uparrow$ & - \\
\hline
\end{tabular}


TSH levels, respectively, and the cyclodiene endrin was associated with higher odds of increased TSH. In addition, the metabolite endosulfan-sulfate was related to lower TSH levels.

In contrast to previous studies, cord blood p'p-DDE levels $(n=221)$ were negatively associated with TSH levels when only male newborns were considered (81). Dallaire et al. (74) reported that prenatal exposure to $\mathrm{HCB}$ was positively associated with FT4 levels in newborns from two fish-eating populations in Quebec ( $n=260$ and $n=410$ ). The authors considered, however, that nutrient confounders including iodine and selenium, may have mitigated the antagonistic effect of OCPs on TH. In 4 year old children $(n=259)$ which were followed in a Spanish birth cohort for examination of TH function, $\mathrm{p}, \mathrm{p}^{\prime}$-DDT and $\beta$ $\mathrm{HCH}$ concentrations in serum were associated with decreased TT3 (70).

Chlordecone was banned in the USA in 1976 but was widely used until the 1993 in the French Caribbean (Martinique and Guadeloupe). In 2015, a longitudinal birth-cohort $(n=111)$ study in Guadeloupe investigated the effects of prenatal and postnatal exposure during breastfeeding. The authors reported that prenatal exposure was associated with increased levels of TSH in boys, while postnatal exposure determined at 3 months was associated with decreased FT3 levels in both genders, and FT4 levels in girls (80).

Taken together, the majority of mother/child cohort results show that OCPs may exert significant $\mathrm{TH}$ inhibitory effects. While several studies in new-borns and children are often considered unsatisfactory due to the lack of significant and concordant effects in both $\mathrm{TH}$ and TSH levels, given the high variability of each parameter, effects on either one can be considered to indicate a hypothyroid-like effect of many organochlorines.

When considering adults, results are more contradictory with some studies reporting effects more in line with hyperthyroidism in men (84), aging women (85) and occupational workers (86), while others found that OCPs were related to clinical or subclinical hypothyroidism in women (87), elderly men (88), adolescents (89) and pesticide applicators (48, 49, 90-92). Moreover, an analysis of data on several organochlorines acquired from the United-States cross-national survey NHANES $^{7}$ did not find an effect of p, $\mathrm{p}^{\prime}$-DDE on TT4 in adults due to inconsistent results in both sampling cycles (1999-2000 and 2000-2001), and associations with TSH were not significant (93).

\section{In vivo Evidence of Thyroid Disruption From Animal Studies}

In vivo studies have proposed several potential mechanisms underlying thyroid disruption by OCPs, majoritarily for DDT (63). Liu et al. (94) exposed male rats for 10 days to $p, p^{\prime}$ DDE and reported a reduction in serum TT4 and FT4 along with decreased levels of transthyretin proteins responsible for T4 transport, upregulation of hepatic enzymes involved in T4 clearance as well as increased hippocampal thyroid hormone receptor mRNA. The effects observed encapsulate previously

\footnotetext{
${ }^{7}$ National Health and Nutrition Examination Survey.
}

suggested modes of action of OCs. Many OCs may act by mimicking $\mathrm{TH}$, binding to TRs along the HPT-axis, decreasing bioactivity of $\mathrm{TH}$ via increased clearance, and/or reducing binding to transport proteins due to their structural similarities to TH (95). Moreover, long-term exposure to low doses of DDT resulted in altered physiology and cytophysiological changes in the follicular epithelium of the thyroid gland to compensate for reduced secretion in thyrocytes $(96,97)$. Likewise, HCB disruption of the HPT-axis is characterized by decreased T4 in male rats, increases in hepatic T4-UDPGT activity along with increased T4 conversion to T3 in the thyroid and liver (98) and competitive inhibition of T4 binding to transporters by its major metabolite pentachlorophenol (PCP) $(99,100)$.

\section{In vitro Evidence of Thyroid Disruption}

In vitro, a first line of evidence was the antagonistic action of DDT in a TSH-induced cAMP production assay (101), the principal second messenger required for thyroid gland activation. Rossi et al. $(102,103)$ investigated this mechanism of action and suggested that DDT could modify the lipid organization of the cell membrane and induce production of extracellular vesicles containing membrane bound TSH receptors (TSHR), thereby inducing failure of the TSH receptor to internalize and prolong TSHR-cAMP signaling. In addition, HCB was shown to reduce viability and inhibit cell cycle progression of FRTL-5 rat thyroid cells along with increased mRNA levels of transforming growth factor-beta (TGF- $\beta 1$ ) known to inhibit cell growth in thyroid epithelial cells (104). In turn, modulation of TGF- $\beta 1$ expression can have repercussions on thyroid function via regulation of thyroid specific genes such as those encoding NIS, thyroglobulin, thyroperoxidase, and the TSH receptor (105).

To conclude on OCPs, multiple mechanisms have been suggested to explain the reduction in circulating THs and/or the increase in TSH. These include displacement from distributor proteins, increased hepatic metabolism, and indirect effects on thyroid function.

\section{ORGANOPHOSPHATE PESTICIDES}

Organophosphates (OPs) pesticides (OPPs) are one of the two main classes of acetylcholinesterase inhibitors, the other being carbamates. During World War II, OPs were used for warfare as a human nerve gas agent, inducing seizures and, at high doses, respiratory arrest (106). Ultimately, OPs were adapted as insecticides because they act on insects via the same mechanism at relatively low doses. The adverse effects of OPs have been widely studied since the 1970s. Remarkably, even low-level prenatal exposure to various OPs, notably chlorpyrifos, can impede normal fetal brain development $(107,108)$. Despite the ban on in-house use in industrialized countries, chlorpyrifos, malathion, and diazinon continue to be extensively used for crop protection (109). After ingestion, most OP pesticides are metabolized, producing different dialkyl phosphate (DAP) metabolites which can be eliminated via urine within $24 \mathrm{~h}$. As DAP metabolites can originate from different OPs, urinary DAP levels give an overview of general $\mathrm{OP}$ exposure rather than being a specific biomarker of a certain OP (110-112). 


\section{Epidemiological Evidence of Thyroid Disruption}

An epidemiological study conducted in California observed that prenatal, but not postnatal, levels of urinary DAP metabolites $(n=329)$ were associated with weaker intellectual development in 7-year-old children, highlighting the vulnerability of the developing fetus (113). In 2012, prenatal low-dose chlorpyrifos (CPF) exposure was associated with differences in brain morphology (107) but no TH related endpoints were measured. Authors of a small cross sectional study $(n=66)$ conducted on children in Indonesia, retrieved questionnaires, analyzed urine samples and measured classical thyroid related endpoints. Six different DAPs, originating from degradation of potentially 28 OPs, were measured in morning spot urine samples. The mean TSH level in children who tested DAP positive was significantly higher than those children with undetectable levels of DAP (114).

In adults, as for OCPs, less data is available. In an extensive prospective health study $(n=30,003)$, agricultural spouses were monitored and followed. The authors found that exposure to organophosphate insecticides was a risk factor for developing several hormonally-related cancers, including breast, thyroid, ovary and lymphoma (115). Further, a study conducted in China $(n=325)$ demonstrated that DAP levels in urine of pregnant women were positively associated with FT4 concentration and negatively with TSH levels, warranting further investigation on the consequences of OP exposure on thyroid function during pregnancy (116). An overview of TH-related epidemiological organophosphate studies can be found in Table 2 .

\section{In vivo Evidence of Thyroid Disruption From Animal Studies}

In vivo, a mouse study reported that a 3-day administration of $\mathrm{CPF}$ at doses under the concentration required for inhibition of brain acetylcholesterinase, could induce histological and histomorphometrical thyroid effects, resulting in hypothyroidism in dams. In the F1, exposed during pre- (3 days) and post-natal (additional 3 days) periods, long-term reductions in serum T4 levels were measured in males 150 days after birth (117). Despite the concentration levels of CPF in this study being much higher than the levels estimated in children (118), these results may still be of significance due to potential additive effects that are likely to occur from continuous exposure to a variety of organophosphorus compounds (see section Mixtures). In addition, Mie et al. (119) reported that the manufacturers' report that was submitted for authorization of chlorpyrifos was misleading as significant effects of exposure on brain development were omitted from conclusions. Specifically, cerebellum height and brain weight were reduced at intermediate doses. As TH is essential for Purkinje cell differentiation in the cerebellum, a thyroid disrupting effect could be hypothesized.

$\mathrm{CPF}$ interferes with maturation of surgeonfish (Acanthurus triostegus) through a thyroid hormone-dependent process. By inhibiting TH levels, chlorpyrifos disrupted metamorphosis and reduced the ability of juveniles to graze algae, an important factor in coral reef maintenance (120). Another fish study conducted a 21-day exposure of OP monocrotophos (MCP) to goldfish (Carassisu auratus). Exposure concentrations were 0.01, 0.10, and $1.00 \mathrm{mg} / \mathrm{L}$. Expression profiles of the HPT axis-responsive genes were altered in the liver, brain, and kidneys, and plasma levels of T3 were decreased (121). This study was repeated in 2018 (122) using lower concentrations of MCP (0, 4, 40, and $400 \mu \mathrm{g} / \mathrm{L})$ and a different exposure protocol (2-, 4-, 8-, and 12days of exposure) and confirmed the $\mathrm{TH}$ disrupting properties of MCP. Also, an economically important teleost species, the Caspian roach (Rutilus rutilus) appears to be vulnerable to organophosphate exposure. Research has shown that when young Caspian roach were exposed to environmentally relevant concentrations of diazinon for $9 \mathrm{~h}$, levels of TSH, T4 and T3, were significantly reduced. Furthermore, cortisol and glucose levels were significantly increased. These alterations of physiology might impact survival rates leading to restocking failures through dwindling numbers of juveniles released into river estuaries (123). Ortiz-Delgado et al. (124) investigated malathion exposure effects in the Senegalese sole, Solea senegalensis, a flatfish whose morphology, obtained gradually through metamorphosis, is THdependent. By exposing fish to malathion (another OPP), the authors demonstrated the sensitivity of this process to this pesticide that is still widely used in developing countries.

\section{In vitro Evidence of Thyroid Disruption}

Qiu et al. (125) used FRTL-5 cells to investigate effects of malathion on TH biosynthesis and showed decreased TSH receptor expression. Toxicogenomics from in vitro experiments aim to identify molecular patterns able to predict in vivo adverse outcomes. This strategy responds to the urgent need for a rapid mechanism-based strategy in risk assessment. In line with this concept, transcriptome analysis was conducted on immortalized rat thyrocytes that were exposed to either CPF or ethylenethiourea (ETU) in order to define in vivo gene signatures and mechanisms of toxicity. They showed non-monotonic dose response curves for both compounds along with common and distinct effects on thyroid toxicity, including altered growth of thyrocytes after chemical exposure to either ETU or CPF. Gene expression based on in vivo experiments fell short of fully recapitulating in vitro predictions because of compensatory and feedback loop mechanisms that are active in vivo. Despite this limitation, in vitro toxicogenomics managed to predict modes of action with longer exposure times. Notably, interference with thyrotrope growth was the main mechanism identified (126).

To conclude on the diverse mechanisms underlying actions of different OPPs on thyroid equilibrium. Both malathion and $\mathrm{CPF}$ could affect thyrotrope production, leading to $\mathrm{TH}$ lowering effects. However for CPF, even though the brain effects. On the other hand, for chlorpyrifos, even though the brain effects have been clearly demonstrated in rats and the TH lowering effects are well-identified in fish, the actual mode of action remains to be clarified in vivo.

\section{Glyphosate}

Glyphosate is an OP compound used worldwide as a broadspectrum herbicide. It binds and competitively inhibits the activity of enolpyruvylshikimate-3-phosphate synthase (EPSPS), an enzyme involved in the shikimic acid pathway (127) only found in plants and micro-organisms (128). Glyphosate usage has 
TABLE 2 | Parameters of epidemiological data retrieved in the review-organophosphates.

Thyroid hormone Pesticide

\begin{tabular}{|c|c|c|c|c|c|c|c|c|c|c|c|c|c|c|c|c|c|c|c|c|c|}
\hline Chemical class & References & Collection & Country & City & Population & $N$ & $\begin{array}{l}\text { Mean age } \\
\text { (years) }\end{array}$ & $\begin{array}{l}\text { Male- } \\
\text { Female }\end{array}$ & Matrix & Time & Matrix & Time & Pesticide name & $\begin{array}{l}\text { Mean } \\
\text { concentration }\end{array}$ & TSH & тт3 & FT3 & TT4 & FT4 & Hypothyroidism & $\begin{array}{l}\text { Other } \\
\text { observations }\end{array}$ \\
\hline \multicolumn{22}{|c|}{ Epidemiology-Organophosphates } \\
\hline Organophosphate & $\begin{array}{l}\text { Suhartono } \\
\text { et al. (114) }\end{array}$ & $\begin{array}{l}\text { March-May } \\
2015 \text { and } \\
\text { August- } \\
\text { October } \\
2015\end{array}$ & Indonesia & $\begin{array}{l}\text { Agricultural } \\
\text { area, brebes } \\
\text { destrict }\end{array}$ & $\begin{array}{l}\text { Children from } \\
\text { elementary } \\
\text { school }\end{array}$ & 66 & 9.2 & $\begin{array}{l}52 \%- \\
48 \%\end{array}$ & Serum & $\begin{array}{l}\text { Cross- } \\
\text { sectional }\end{array}$ & $\begin{array}{l}\text { Morning } \\
\text { spot urine }\end{array}$ & $\begin{array}{l}\text { Cross- } \\
\text { sectional }\end{array}$ & $\begin{array}{l}6 \text { DAP } \\
\text { metabolites }\end{array}$ & Not indicated & $\uparrow$ & & - & & ns & $\begin{array}{l}\uparrow \text { with positive } \\
\text { urinary } \\
\text { ogranophosphate } \\
\text { pesticide } \\
\text { metabolites }\end{array}$ & - \\
\hline Organophosphate & $\begin{array}{l}\text { Lerro et al. } \\
(115)\end{array}$ & 1993-1997 & $\begin{array}{l}\text { North- } \\
\text { America }\end{array}$ & $\begin{array}{l}\text { lowa and North } \\
\text { Carolina }\end{array}$ & $\begin{array}{l}\text { Spouses of } \\
\text { pesticide } \\
\text { applicators }\end{array}$ & 30,003 & & $\begin{array}{c}0 \%- \\
100 \%\end{array}$ & $\begin{array}{l}\text { Detailed } \\
\text { self- } \\
\text { reported } \\
\text { use of } \\
\text { pesticides. }\end{array}$ & $\begin{array}{l}\text { Detailed } \\
\text { self- } \\
\text { reported } \\
\text { use of } \\
\text { pesticides. }\end{array}$ & $\begin{array}{l}\text { Detailed } \\
\text { self- } \\
\text { reported } \\
\text { use of } \\
\text { pesticides. }\end{array}$ & $\begin{array}{l}\text { Detailed } \\
\text { self- } \\
\text { reported } \\
\text { use of } \\
\text { testicides. }\end{array}$ & $\begin{array}{l}\text { Detailed } \\
\text { self-reported use } \\
\text { of pesticides. }\end{array}$ & $\begin{array}{l}\text { Detailed self-reported - } \\
\text { use of pesticides. }\end{array}$ & & & & & & , & $\begin{array}{l}\uparrow \text { risk with OP } \\
\text { use for serval } \\
\text { hormonally- } \\
\text { related } \\
\text { cancers } \\
\text { including } \\
\text { thyroid cancer }\end{array}$ \\
\hline \multirow[t]{5}{*}{ Organophosphate } & \multirow[t]{5}{*}{$\begin{array}{l}\text { Wang et al. } \\
(116)\end{array}$} & \multirow{5}{*}{$\begin{array}{l}\text { April 2011- } \\
\text { December } \\
2013\end{array}$} & \multirow[t]{5}{*}{ China } & \multirow{5}{*}{$\begin{array}{l}\text { Southern } \\
\text { coastal area of } \\
\text { Laizhou Wan } \\
\text { (Bay) of Bohai } \\
\text { Sea in } \\
\text { Shandong } \\
\text { Province }\end{array}$} & \multirow{5}{*}{$\begin{array}{l}\text { Pregnant } \\
\text { f women }\end{array}$} & \multirow[t]{5}{*}{325} & \multirow[t]{5}{*}{28.4} & \multirow[t]{5}{*}{$\begin{array}{l}0 \%- \\
100 \%\end{array}$} & \multirow[t]{5}{*}{ Serum } & \multirow[t]{5}{*}{$\begin{array}{l}\text { cross- } \\
\text { sectional }\end{array}$} & \multirow[t]{5}{*}{ Urinary } & \multirow[t]{5}{*}{$\begin{array}{l}\text { cross- } \\
\text { sectional }\end{array}$} & $\begin{array}{l}6 \text { DAP metabolits: } \\
\text { Sum DAP }\end{array}$ & & $\downarrow$ & ns & ns & ns & $\uparrow$ & & \\
\hline & & & & & & & & & & & & & DMP & $9.81 \mu \mathrm{g} / \mathrm{L}$ & ns & ns & ns & ns & ns & & \\
\hline & & & & & & & & & & & & & DMTP & $0.79 \mu \mathrm{g} / \mathrm{L}$ & ns & ns & ns & ns & ns & - & - \\
\hline & & & & & & & & & & & & & DEP & $5.00 \mu \mathrm{g} / \mathrm{L}$ & ns & ns & ns & ns & ns & & \\
\hline & & & & & & & & & & & & & DETP & $0.78 \mu \mathrm{g} / \mathrm{L}$ & ns & ns & ns & ns & ns & & - \\
\hline \multirow[t]{4}{*}{$\begin{array}{l}50 \text { different } \\
\text { pesticides }\end{array}$} & \multirow[t]{4}{*}{$\begin{array}{l}\text { Shrestha et al. } \\
\text { (91) }\end{array}$} & \multirow[t]{4}{*}{ l. 1991-1997 } & \multirow[t]{4}{*}{$\begin{array}{l}\text { North- } \\
\text { America }\end{array}$} & \multirow[t]{4}{*}{$\begin{array}{l}\text { North Caroline } \\
\text { and lowa }\end{array}$} & \multirow[t]{4}{*}{$\begin{array}{l}\text { Pesticide } \\
\text { applicators }\end{array}$} & \multirow[t]{4}{*}{35,150} & \multirow[t]{4}{*}{$\begin{array}{l}\text { Median age } \\
62\end{array}$} & \multirow[t]{4}{*}{$\begin{array}{c}97.9 \%- \\
2.1 \%\end{array}$} & \multirow{4}{*}{$\begin{array}{l}\text { Detailed } \\
\text { self- } \\
\text { reported } \\
\text { use of } \\
\text { pesticides. }\end{array}$} & \multirow{4}{*}{$\begin{array}{l}\text { Detailed } \\
\text { self- } \\
\text { reported } \\
\text { use of } \\
\text { pesticides. }\end{array}$} & \multirow{4}{*}{$\begin{array}{l}\text { Detailed } \\
\text { self- } \\
\text { reported } \\
\text { use of } \\
\text { pesticides }\end{array}$} & \multirow{4}{*}{$\begin{array}{l}\text { Detailed } \\
\text { self- } \\
\text { reported } \\
\text { use of } \\
\text { pesticides. }\end{array}$} & Diazinon & - & & - & - & & - & $\uparrow($ attained age) & - \\
\hline & & & & & & & & & & & & & Dichlorvos & & & & & & & $\uparrow$ (attained age) & \\
\hline & & & & & & & & & & & & & Malathion & - & - & - & - & - & - & $\uparrow$ (attained age) & - \\
\hline & & & & & & & & & & & & & Glyphosate & - & - & - & - & - & - & $\uparrow$ (attained age) & - \\
\hline \multirow[t]{3}{*}{$\begin{array}{l}50 \text { different } \\
\text { pesticides }\end{array}$} & $\begin{array}{l}\text { Goldner et al. } \\
\text { (91) }\end{array}$ & . 1993-1997 & $\begin{array}{l}\text { North- } \\
\text { America }\end{array}$ & $\begin{array}{l}\text { North Caroline } \\
\text { and lowa }\end{array}$ & $\begin{array}{l}\text { Pesticide } \\
\text { applicators }\end{array}$ & 22,246 & 45.6 & $\begin{array}{l}100 \%- \\
0 \%\end{array}$ & $\begin{array}{l}\text { Self- } \\
\text { reported }\end{array}$ & $\begin{array}{l}\text { Self- } \\
\text { reported }\end{array}$ & $\begin{array}{l}\text { Detailed } \\
\text { self- }\end{array}$ & $\begin{array}{l}\text { Detailed } \\
\text { self- }\end{array}$ & Diazinon & - & & - & - & & - & $\uparrow$ & \\
\hline & & & & & & & & & $\begin{array}{l}\text { thyroid } \\
\text { disease }\end{array}$ & $\begin{array}{l}\text { thyroid } \\
\text { disease }\end{array}$ & $\begin{array}{l}\text { reported } \\
\text { use of }\end{array}$ & $\begin{array}{l}\text { reported } \\
\text { use of }\end{array}$ & Malathion & & & & & & & $\uparrow$ & \\
\hline & & & & & & & & & & & pesticides. & pesticides. & Glyphosate & - & - & - & & - & - & ns & - \\
\hline $\begin{array}{l}\text { Total of } 33 \\
\text { pesticides (16 }\end{array}$ & $\begin{array}{l}\text { Lerro et al. } \\
\text { (92) }\end{array}$ & $\begin{array}{l}\text { June 2010- } \\
\text { September }\end{array}$ & $\begin{array}{l}\text { North- } \\
\text { America }\end{array}$ & $\begin{array}{l}\text { lowa or North } \\
\text { Carolina }\end{array}$ & $\begin{array}{l}\text { Pesticide } \\
\text { applicators }\end{array}$ & 679 & $\begin{array}{l}\text { Not } \\
\text { indicated }\end{array}$ & $\begin{array}{l}100 \%- \\
0 \%\end{array}$ & Serum & $\begin{array}{l}\text { Cross- } \\
\text { sectional }\end{array}$ & $\begin{array}{l}\text { Detailed } \\
\text { self- }\end{array}$ & $\begin{array}{l}\text { Detailed } \\
\text { self- }\end{array}$ & $\begin{array}{l}\text { Chlorpyrifos } \\
\text { Diazinon }\end{array}$ & : & $\begin{array}{l}\text { ns } \\
\text { ns }\end{array}$ & $\begin{array}{l}\text { ns } \\
\text { ns }\end{array}$ & : & $\begin{array}{l}\text { ns } \\
\text { ns }\end{array}$ & : & $\begin{array}{l}\text { ns } \\
\text { ns }\end{array}$ & : \\
\hline herbicides, 13 & & 2013 & & & & & & & & & reported $\mathrm{r}$ & reported & Fonofos & - & ns & ns & - & ns & - & ns & - \\
\hline $\begin{array}{l}\text { Insecticides, two } \\
\text { fungicides, two }\end{array}$ & & & & & & & & & & & pesticides. F & . pesticides. & Malathion & - & ns & ns & - & ns & - & ns & - \\
\hline fumigants) & & & & & & & & & & & & & glyphosate & - & ns & ns & - & ns & - & ns & - \\
\hline
\end{tabular}


increased tremendously since Monsanto introduced glyphosatetolerant crop varieties in 1996 (namely, sugar beet, canola, cotton, maize, alfalfa) to be used in conjunction with Roundup, the glyphosate-based formulation (129). The median half-life of glyphosate in the field is reportedly 47 days and the primary breakdown products are aminomethylphosphonic acid (AMPA) and glyoxylate (130).

\section{Epidemiological Evidence of Thyroid Disruption (Three Studies)}

A prospective cohort study of licensed pesticide applicators in North Carolina and Iowa with 35,150 male and female participants demonstrated that self-reported use of glyphosate was associated with increased risk of hypothyroidism (91). However, these findings are not consistent with results obtained from the same cohort study conducted by Goldner et al. (49) and Lerro et al. (92).

\section{In vivo Evidence of Thyroid Disruption}

Surprisingly, few studies retrieved were found to be relevant to glyphosate exposure and thyroid endpoints. In a first in vivo study, female pregnant Wistar rats were exposed to either 5 or $50 \mathrm{mg} / \mathrm{kg} /$ day Roundup ${ }^{\circledR}$ Transorb (Monsanto) from gestation day 18 to post-natal day (PND) 5. Blood and tissues samples from heart, liver, pituitary and hypothalamus were collected for hormonal, metabolomics or gene expression analysis at PND 90. In every tissue collected, TH-related genes were observed to be differentially expressed in exposure groups compared to the control group. Levels of TSH were decreased in exposure groups, however levels of both T3 and T4 were unaffected. This curious lack of TH hormone effects, despite TSH and target gene changes, may reflect changes in TSH set-point resulting from differential gene programming in rats during the fetal period (131).

Due to the removal of patent protection for glyphosate in 2000, many new glyphosate-based herbicides arrived on the pesticide market. Each of these formulations have a slightly altered surfactant mixture and chemistry, making testing procedures even more complicated. The second in vivo study, exposed four different North American amphibian species (Rana clamitans, Rana pipiens, R. sylvatica, and Bufo americanus) to glyphosate and the surfactant polyethoxylated tallowamine (POEA), and six different glyphosate-based formulations. Disruption of the HPT-axis was investigated by measuring time to metamorphosis and expression of thrb. Glyphosate alone and formulations lacking POEA were the least toxic, however R. pipiens tadpoles showed delayed metamorphosis and decreased snout-vent length at the peak of metamorphosis after exposure to either POEA or glyphosate formulations containing POEA. These effects may be linked to the increased thrb mRNA levels observed in the same exposure conditions. This study underlines the need for surfactant composition to be taken into consideration in the evaluation of risk assessment of glyphosate-based herbicides (132). In another frog study (Lithobates sylvaticus), glyphosate-formulated exposure alters brain gene expression for thrb and dio3 enzyme, with different alterations depending on the stage (133).
Clearly, how and at which levels glyphosate has the potential to interfere with $\mathrm{TH}$ equilibrium in different species has not yet been fully examined. However, one area that remains to be investigated is microbiome metabolism. As human, vertebrate and invertebrate microbiomes express the EPSPS enzyme, it is plausible that microbiome status is modified by short or longterm glyphosate exposure.

\section{CARBAMATES}

Carbamates are widely used in agriculture, principally as insecticides, but also as herbicides and fungicides. Although they differ chemically from organophosphates, they act similarly by inhibiting the acetylcholineresterase enzyme (AChE) at the level of neuronal synapses. AChE is responsible for the rapid hydrolytic degradation of the neurotransmitter ACh into inactive products at neuromuscular junctions. In general, the AChE inhibition by carbamates is reversible in contrast with OPs (134). We focused here on the subgroup of dithiocarbamates in which, both oxygen atoms are replaced by sulfur. Dithiocarbamates can be sub-divided into two major groups: ethylenebisdithiocarbamates (EBDC) which includes maneb, zineb, and mancozeb, and dimethyldithiocarbamates (DMDC) consisting of ferbam, ziram and thiram. ETU is one of the major metabolites of EBDCs in mammals (135) whereas carbon disulfide is a metabolite found after in vivo DMDC treatment (136). As the thioureas can inhibit thyroid peroxidase, a thyroid gland enzyme essential for $\mathrm{TH}$ production, pesticides that generate ETU metabolites are of particular concern (55).

\section{Epidemiological Evidence of Thyroid Disruption}

Chronic exposure to EBDCs mainly concerns agricultural and industrial workers but also the general population which may be continuously exposed to residues present in food (137). An overview of the epidemiological carbamate studies can be found in Table 3. In Costa Rica, mancozeb is applied weekly on banana plantations by light aircraft. Urinary ETU concentrations of pregnant women living in the vicinity of plantations $(n=$ 451) were more than five times higher than concentrations reported in general populations (138). In 2017, a large epidemiological study was conducted in Taiwan to investigate the association between hypothyroidism and anticholinesterase pesticide poisoning (organophosphate and carbamate). A total of 10,372 subjects poisoned by anticholinesterase pesticides were compared to 31,116 reference subjects between 2003 and 2012 . Analysis demonstrated that exposed subjects had significantly increased risk for hypothyroidism (139). A smaller study was conducted on 177 occupationally exposed male workers in Italy and confirmed the thyroid disrupting effect of mancozeb (140).

\section{In vivo Evidence of Thyroid Disruption From Animal Studies}

A rat study conducted in 1985 demonstrated that both EBDCs maneb and zineb could affect endogenous TRH at the pituitary or hypothalamic level and therefore inhibit TSH secretion (141). 


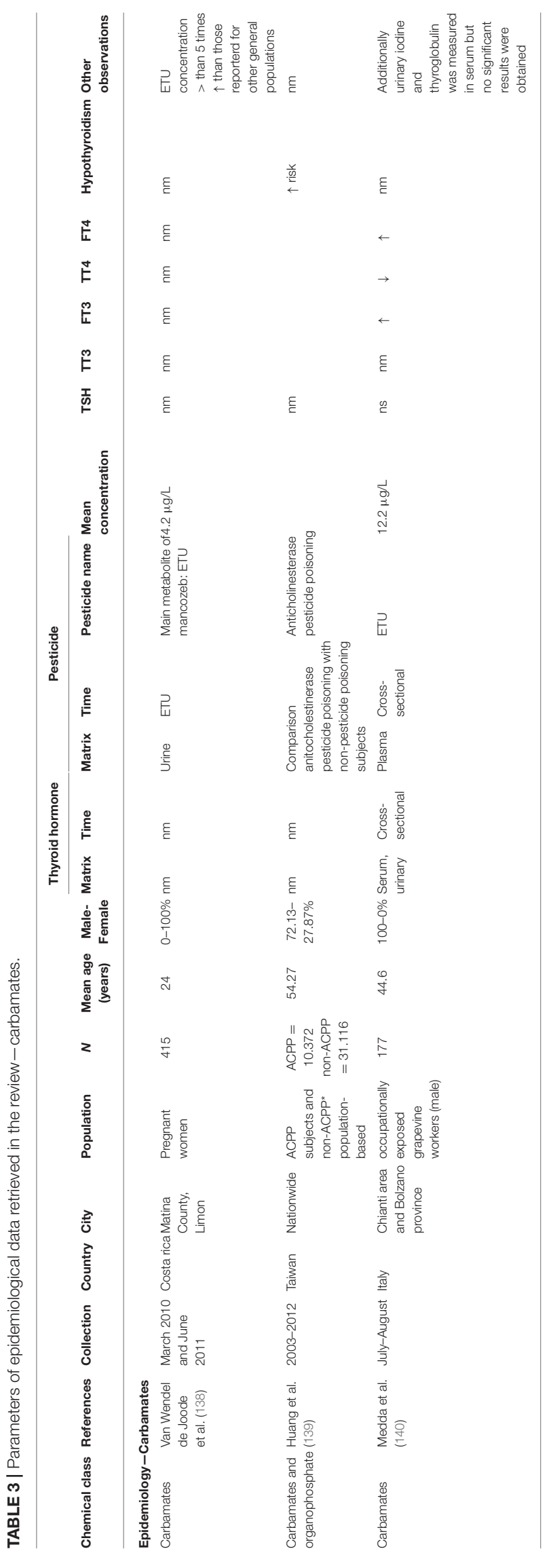

At the level of the thyroid gland, Mancozeb was shown to reduce TPO activity, consequently altering both weight and histopathology of the thyroid gland, with acute high dose exposure resulting in a hypothyroid status in rats $(142,143)$.

A zebrafish study exposed embryos to $0.001-10 \mu \mathrm{M}$ thiram, at various developmental stages for a short duration of time $(1 \mathrm{~h})$. Thiram exposure increased dio 3 mRNA expression a 12 hpf and decreased tpo mRNA expression at $48 \mathrm{hpf}$. In addition, delayed hatching, increased mortality, and skeletal defects were observed. The extent to which the disruption of the HPT axis contributed to these specific adverse outcomes needs further investigation (144).

\section{In vitro Evidence of Thyroid Disruption}

The effects of ziram, thiram, zineb, and ETU have been investigated in vitro, on Chinese hamster ovary cells transfected with the human TPO gene. Zineb $(50 \mu \mathrm{M})$ inhibited the iodinating activity of TPO at a 10 -fold higher concentration than its metabolite, ETU, indicating that ETU is the ultimate toxicant in vivo. No effect was observed with DMDCs, thiram and ziram (145).

To conclude on carbamates, a major concern is the effects of many metabolites on TPO activity. A major gap to be filled is that there is little epidemiological data available on exposure levels in the environment and general population.

\section{PYRETHROIDS}

Pyrethrins are found in Chrysanthemum flowers and serve as a natural system of protection against insects (146). One major limitation of organic pyrethrins is their fast photodegradation leading to limited usage in agriculture. Hence, researchers established a more stable synthetic compound, labeled pyrethroids (PYRs), based on the chemistry of natural pyrethrins. The chemical structures of PYRs are comparable across the group and retain the essential acid/alcohol configuration of pyrethrins. Both groups block normal nerve impulses by preventing closure of voltage-gated sodium channels in axonal membranes, thereby paralyzing and eventually killing the organism (147).

Currently, PYRs represent a major class of insecticides worldwide, with more than $14 \%$ of the total pesticide market in 2005 (148). The most common PYRs include allethrin, bifenthrin, cyfluthrin, $\lambda$ cyhalothrin, cypermethrin, deltamethrin, permethrin, d-phenothrin, fenvalerate, resmethrin, and tetramethrin (149). Two frequent metabolites, 3-(2,2-dichlorovinyl)-2,2-dimethylcyclopropne carboxylic acid (DCCA) and 3-phenoxybenzoic acid (3-PBA), are non-specific metabolites of several different PYR insecticides (150).

The major route of exposure for humans is through ingestion of food items treated with PYRs (151). Even though PYRs have relative short half-lives ranging from 3- to 96-days in soil (152), they are found in environmental samples $(153,154)$, human samples (155) and food (156), probably as a result of excessive and repeated use. Given PYRs structural resemblance to T3 and T4, PYRs insecticides are suspected to act as TH disruptors (150). 
An overview of the epidemiological PYR studies can be found in Table 4.

\section{Epidemiological Evidence of Thyroid Disruption}

As determined by urinary levels of metabolites to estimate internal exposure, human exposure to PYRs is widespread (155). Pregnant women are of particular concern given the vulnerable window of prenatal exposure to pesticides that could lead to impairment of normal development of offspring. The most commonly detected PYR metabolite is 3-PBA, a breakdown product of several PYR, that has been repeatedly measured in urine of pregnant women. However, no association was found between maternal TH serum levels and PYR exposure (157). Concealed behind this outcome remain important facts that should be taken into consideration: (i) both PYRs and their metabolites have the capacity to induce antagonistic effects on TRs (ii) they are able to transfer to the placenta $(150,158,159)$. It might be prudent to carry out more regular measurements of $\mathrm{TH}$ levels in women exposed to PYRs and eventually examine offspring for $\mathrm{TH}$ related effects.

\section{In vivo Evidence of Thyroid Disruption From Animal Studies}

In adult rats, two separate in vivo studies observed alterations of $\mathrm{TH}$ levels in serum using different PYRs and distinct exposure protocols $(160,161)$, suggesting that PYRs are potential thyroid disruptors. In another rodent study, pregnant mice were orally administered a PYR (fenvalerate) throughout pregnancy on a daily basis. Quantitative analysis of mRNA in the placenta of exposed mice showed a reduction of TR $\alpha 1$ and TR $\beta 1$ transcripts. Additionally, fetal intrauterine growth retardation (IUGR) was observed in offspring that were exposed during embryonic development. Following the observation of altered maternal THs together with IUGR, one may hypothesize that disruption of placental TR mRNA could explain poor fetal intrauterine growth (162). Furthermore, a study using lizards (Eremias argus) as a model organism showed that a 21 -day exposure to $\lambda$ cyhalothrin alters the expression of TH-related genes in the liver (163). A zebrafish study demonstrated that permethrin, one of the most frequent pyrethroids, significantly increased expression of major thyroid signaling genes (thyroid hormone receptors, deiodinases, thyroid-stimulating hormone) as well as transthyretin (TTR) protein in zebrafish larvae, after a single 3day embryonic exposure. Additionally, the same research group showed that permethrin has the potential to alter TTR activity by docking to TTR's active pocket (164). This research group also identified bifenthrin and $\lambda$-cyhalothrin as disruptors of the HPT axis in zebrafish embryos. The majority of the genes examined related to the HPT axis (tpo, dio1, dio2, thra, thrb, ttr) were found to be upregulated (165). Another zebrafish study tested two PYRs (permethrin and $\beta$-cypermethrin) and three metabolites: 3-phenoxybenzoic alcohol (PBCOH), 3-phenoxybenzaldehyde (PBCHO), and 3-phenoxybenzoic acid (PBCOOH). The study demonstrated that both PYRs and their metabolites exert effects on TH signaling, locomotor behavior and development of

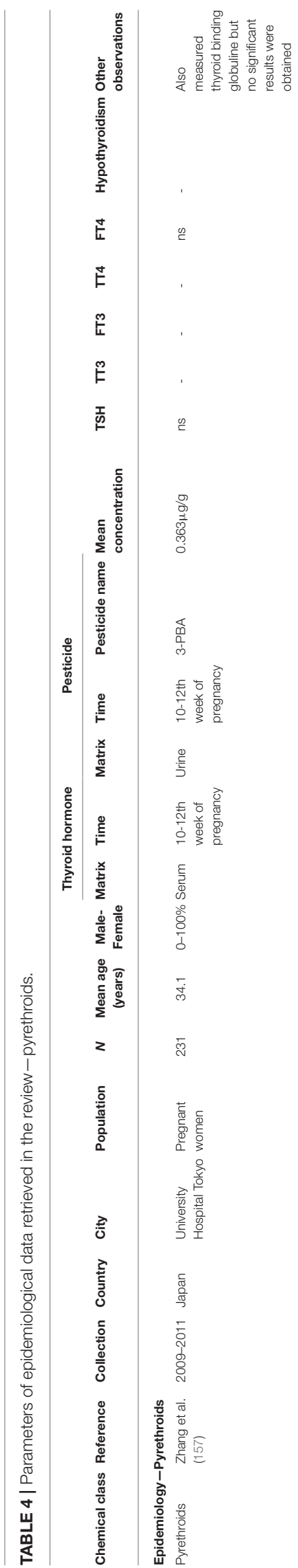


embryonic zebrafish. The observed thyroid disruption may play a role in the aberrant larval development (166).

An additional factor that should be taken into consideration is that fish are vulnerable to changes in temperature attributable to global climate change and that the increase in temperature might exacerbate the effect of chemical exposure. One study conducted by Giroux et al. (167) investigated both the effects of higher temperature and pyrethroid (bifenthrin) exposure on TH signaling. To better understand the possible interaction between pesticide exposure and temperature on salmon development, researchers reared the fish at different temperature $(11,16.4$, and $\left.19^{\circ} \mathrm{C}\right)$ and exposed them at different concentrations $(0$, 0.15 , and $1.5 \mu \mathrm{g} / \mathrm{L}$ ) of bifenthrin for $96 \mathrm{~h}$. Final results revealed decreased survival with increasing temperatures. Following pesticide exposure, TH levels were either significantly increased in the case of juvenile exposure in warm water and tended to decrease during fry stages at low temperatures. These adverse sub-lethal effects could have long-term consequences for populations, such as those featured in this study in California which are affected by both a seasonal rainstorm runoff containing pyrethroid pesticides and increasingly warmer waters.

\section{In vitro Evidence of Thyroid Disruption}

An in vitro research reported that an array of PYR insecticides (cycloprothrin, cyfluthrin, cyhalothrin, cypermethrin, deltamethrin, etofenprox, fenvalerate, permethrin, and tetramethrin) and their prevalent metabolite, 3-PBA, have the potential to disrupt $\mathrm{TH}$ signaling. By making use of a receptor-mediated luciferase reporter gene assay, Diu et al. (150) demonstrated that the aforementioned PYRs, of similar chemical structure, exert antagonistic action on the TH receptor and therefore impede the TH axis. The potential for PYRs and their metabolite to interact with androgen or estrogen receptor was also investigated. Interestingly, results suggested that, in the case of estrogen signaling, the metabolites rather than their parent compound should be given greater concern as they were up to 1,000 -times more potent in their interaction with the receptor (150).

To conclude on pyrethrins, their structural resemblance to $\mathrm{THs}$, with the fact that in vitro and in vivo animal studies demonstrate clear interference with TH homeostasis and action argues for more caution in their use and more intense scrutiny of their long-term effects.

\section{PHENYLPYRAZOLE}

Fipronil, the most representative synthetic pesticide of the phenylpyrazole family, is a broad-spectrum insecticide and acaricide. This "second generation" pesticide is widely used in crop protection in urban areas for insect control and in veterinary practice for its efficiency against domestic animal ectoparasites (168). As fipronil usage has increased rapidly since its introduction in 1993-accounting for approximately $10 \%$ of the global pesticide market $(169,170)$, it has also become a widespread environmental contaminant detected in both soil and water $(171,172)$, indoor and outdoor dust (173) as well as in various food matrices as highlighted by the recent egg contamination scandal $\left[(174,175)^{8}\right]$ Fipronil was partially restricted in 2013 and prohibited for outdoor use in most EU nations during flowering periods after its suspected involvement in the historical mass mortalities of honey bees (176). However, this decision was recently overturned by the European court due to insufficient impact assessment (177). Fipronil is still used as a biocide for ants and cockroaches as pests in the $\mathrm{EU}$, but there has not been an application for its re-registration for use as a systemic pesticide in agriculture (178). Initially introduced after increasing resistance to organophosphate, pyrethroid and carbamate pesticides (170), its neurotoxicity arises from non-competitive blocking of gamma-aminobutyric acid (GABA)-gated chloride channels resulting in excessive neuronal stimulation and death. Its specificity for target organisms derives from its higher affinity for invertebrate GABA-A and GABA-C receptors than those of mammals $(169,179,180)$.

Adverse effects were found in numerous non-target organisms including beneficial insects such as bees and termites, and vertebrates including fish, reptiles, birds, and mammals (168). In addition to hepatotoxic, nephrotoxic, anti-reproductive, and cytotoxic effects (180). Alarmingly, the primary metabolite fipronil-sulfone and the photodegradate fipronil-desulfinyl are both biologically active and are considerably more toxic, persistent, bioaccumulative, and less selective than the parent compound (181-187). Since fipronil is rapidly metabolized into the sulfone metabolite which has a longer half-life $(208 \mathrm{~h}$ instead of $8.5 \mathrm{~h}$ in rats) and a six-fold greater binding capacity to vertebrate GABA receptors than fipronil (181), fipronil-sulfone has been suggested as the main mediator for fipronil-induced toxicity $(180,187,188)$.

\section{Epidemiological Evidence of Thyroid Disruption}

In human studies, serum fipronil-sulfone, the main metabolite of fipronil, was inversely correlated with serum TSH levels in factory workers manufacturing veterinary drugs containing fipronil, suggesting a central inhibitory effect on TSH secretion (189). While exposure of the general population is lower than occupational exposure, fipronil exposure can nonetheless affect sensitive populations such as newborn infants. In a pregnancybirth cohort study, maternal fipronil-sulfone was reported to be placentally transferred to newborn infants along with exposure levels inversely correlated with FT3 levels in both cord blood and newborns (169). Furthermore, fipronil-sulfone concentrations were negatively associated with 5-min Apgar scores (a method used for assessing new born status immediately after birth and a biomarker of developmental vulnerability) (190). An overview of the epidemiological fipronil studies can be found in Table 5 .

\section{In vivo Evidence of Thyroid Disruption From Animal Studies}

Exposure to fipronil caused tumors in rats via hypertrophy of thyroid follicles (191) and altered the integrity of follicular cells, thyroid tissue and even the chemical composition of the colloid in mice $(186,192)$. Moreover, fipronil exposure decreased

\footnotetext{
${ }^{8} \mathrm{https}: / /$ www.bbc.com/news/world-europe-40878381
} 


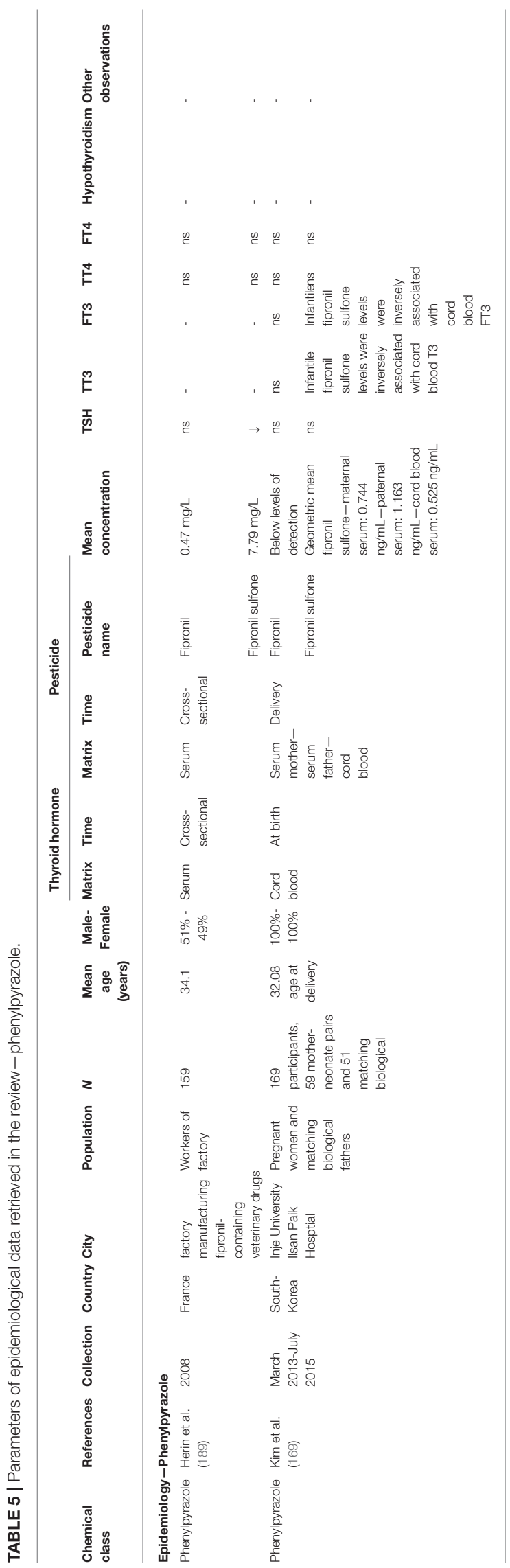

circulating TH levels in rats, at least partially mediated by increased clearance following elevated activity and expression of phase II hepatic enzymes $(186,187,193,194)$.

\section{In vitro Evidence of Thyroid Disruption}

Using in vitro reporter gene assays, fipronil-sulfone showed antagonistic activity via TR $\beta$ in a dose-dependent manner, suggestive of another potential mechanism of action for the thyroid disrupting effect of fipronil (195).

\section{NEONICOTINOIDS}

Neonicotinoids are a relatively new class of broad-spectrum insecticides discovered in the 1980s and widely used today in agriculture for their systemic properties (170), but also in commercial, residential and veterinary settings (196). The global insecticide market, previously dominated by carbamates, organophosphates and pyrethroids was reshaped in 2008 when neonicotinoids represented over a quarter of the market. In 2008, the neonicotinoid imidacloprid (IMI) was the world's largest selling insecticide, second only to the herbicide glyphosate $(170,197)$. Currently, the main neonicotinoids on the market are imidacloprid, thiamethoxam, thiacloprid, clothianidin, acetamiprid, nitenpyram, and dinotefuran, however the first three were recently banned for outdoor use in Europe during flowering, following demonstrated risks to bees and other pollinators. Structurally similar to the natural insecticide nicotine-historically used for centuries as an early insecticide, neonicotinoids have enhanced selectivity and potency for the insect nicotinic acetylcholine receptor (nAChR), compared to vertebrate nAChR subtypes, and relatively poor penetration of the mammalian blood-brain barrier, translating into apparent reduced health risks for mammals, birds and fish $(196,198)$. The insecticidal activity of neonicotinoids originates from binding to nAchRs, triggering a large influx of cations in the postsynaptic membrane of nerve cells in the central nervous system, causing excessive excitatory neurotransmission which results in paralysis and death (198).

\section{Epidemiological Evidence of Thyroid Disruption}

Although there is no epidemiology of TH levels in humans exposed to neonicotinoids, there is one report of reduced IQ as a function of prenatal exposure to neonicotinoids and pyrethyroids (199).

\section{In vivo Evidence of Thyroid Disruption}

Pandey and Mohanty (142) examined potential thyroid disrupting effects in wild male finches exposed to IMI under laboratory conditions. They reported altered thyroid histopathology including increases in thyroid weight and volume, hypertrophy and hyperplasia of epithelial and stromal cells, decreases in plasma T4, T3 and TSH levels. It should be noted that a commercial formulation of IMI was utilized which contains multiple potentially bioactive ingredients (200). 


\section{In vitro Evidence of Thyroid Disruption}

A TH-dependent proliferation assay (T-screen) with GH3 cells was employed to investigate the thyroid disrupting potential of common neonicotinoids, but none of the 7 neonicotinoids tested had any effect on TH-dependent proliferation (200) in the absence of T3. However, Xiang et al. (201) showed that IMI exerted agonist effects in a GH3 luciferase reporter gene assay mediated via TR which was further characterized using human $\mathrm{TR} \beta$ in a Surface Plasmon Resonance biosensor technique to measure binding kinetics. Moreover, in silico molecular docking (MD) analysis predicted that IMI may compete with T3 for binding with TR by forming hydrogen bonds with the imidazole group (202).

Overall, despite their widespread use, relatively few studies have investigated the potential thyroid disrupting effects of neonicotinoids, but many have examined the effects of neonicotinoids in mixtures containing various classes of pesticides, which is more in line with the reality of environmental exposure.

\section{MIXTURES}

Humans are simultaneously exposed to myriads of chemicals that may act in concert to induce mixture effects. Currently, risk assessment is focused on examining chemicals individually, without taking into account potential toxic effects of lowdose combinations of EDCs. Frequently, in agricultural practice, multiple pesticides are preferentially used to reduce resistance to an individual pesticide and enhance efficacy (203). In the case of combined exposure with one or more families of different pesticides, several modes-of-action could be involved. Furthermore, each chemical may interfere with another, resulting in complex dose-response interactions (204). It is important to mention that in most cases EDC responses, as well as hormones, do not show the typical monotonic dose responses classically used in toxicology studies but rather follow non-monotonic dose responses (NMDR) (16). A first and widely used model in toxicology is the dose addition model (DA). DA assumes that toxicity can be expected if the sum of the concentration of each compound of the mixture is high enough to surpass the threshold of toxicity of the mixture, regardless of the fact that the concentration of each compound is below its own effect threshold (205). A conventional term for threshold is the No Observed Adverse Effect Levels (NOAELs). NOAELs are used to deduce regulatory threshold values applying an uncertainty factor, typically of 100 resulting from a factor of 10 to take into account interspecies extrapolations and another factor of 10 considering intra-species variability (206). Another concept is the principle of Response Addition (RA) used to assess the toxicity of a mixture containing compounds with different modes of action (207). Consequently, models integrating the concepts of DA and RA are needed to investigate complex mixtures of chemicals with both similar and dissimilar modes of action, a so-called "integrated-addition model" (208). Several studies have undertaken a "whole mixture approach." In this approach a combination of chemicals is considered as a single compound even if specific effects of each component are not investigated $(209,210)$. While studying complex mixtures is necessary, extrapolating from one mixture to another is difficult knowing that small changes in composition can possibly lead to differences in outcomes (211). An example of application of whole mixture approach is that the in vivo identified animal model dose-response relationship of the mixture can determine a reference dose (RfD) associated with an adverse health outcome in vivo. A statistical measure of "sufficient similarity" of the $\mathrm{RfD}$ can be used to compare the RfD with EDC exposure levels assessed in the human population to generate a "similar mixture risk indicator" in order to identify people at risk. The systematic integration of experimental animal studies and epidemiological studies may improve the scientific understanding of implicated health effects and improve risk assessment of EDCs (212).

\section{In vivo Evidence of Thyroid Disruption}

A study exposed rats for 4-days to different $\mathrm{TH}$ synthesis inhibitors (pesticides: thiram, pronamide, and mancozeb) and stimulators of T4 liver clearance [polyhalogenated aromatic hydrocarbons (PHAHs): 2 dioxins, 4 dibenzofurans; and 12 PCBs including dioxin-like and non-dioxin like polychlorinated biphenyls (PCBs)], and compared the decrease in T4 serum levels with the three aforementioned models' predictions (response addition, dose addition and integrated addition as explained above). Rats exposed to highest dose of the mixture demonstrated a $45 \%$ reduction of serum T4. Results from this study support both the dose- and integrated-addition model as they provided a better prediction than the response-addition model (213). Another study conducted by Wu et al. (214) observed synergistic effects between the organophospate triazophos (TRI) and the neonicotinoid, imidacloprid, when investigating combined toxicities in zebrafish. mRNA levels of dio1, dio2, and tsh were more affected in joint exposure compared to their individual pesticide exposure, underlining the importance to incorporate joint toxicity studies. Due to specific action of each compound, a mixture of the insecticide IMI in co-exposure with the fungicide mancozeb (MCZ) is frequently used in the field. Therefore, another mixture study used this combination to mimic reallife exposure for both wild animals and human beings. One focus of this study was the assessment of differences in body weight of mice exposed via lactation to low doses of the two pesticides. First, in silico molecular docking (MD) was used to predict the probable binding modes of pesticides with THRs (alpha and beta). MD showed both compounds could compete with active $\mathrm{TH}$ for TR binding. No effect on body weight was seen with individual exposure whereas low dose exposure to a combination of both pesticides induced significant gain in relative body weight. This increase in weight might be a consequence of $\mathrm{TH}$ imbalance as, additionally, significant decreases in THs (both T3 and T4) and increases of TSH in blood plasma were observed in mice exposed to the mixture (202). Another study exposed rats to the four most widely used OP insecticides (dichlorvos, dimethoate, acephate, and phorate) in agriculture in China and identified that these pesticides elicit a joint toxic response. Rats were given the mixture via drinking water for a period of 24 weeks and plasma was 
analyzed by metabolomics. Levels of iodotyrosine, an early precursor to T4, were decreased, suggesting that exposure to an OP mixture can alter thyroid gland function (215). As there is increasing emphasis on the use of blood-based biomarkers of adverse outcomes in safety assessment, other studies have evaluated targeted metabolite profiles after exposure to different chemical groups (193). Given the "one health" concept, with human health being related to that of biodiversity and the environment, non-target organisms of pesticides are a concern for human well-being. A study on the seasonally breeding finch, Amandava amandava demonstrated that when co-exposed to a dithiocarbamate (mancozeb/MCZ) and a neonicotinoid IMI, both thyroid homeostasis and reproductive axis were affected. A 30-day exposure to this mixture via food intake, at concentrations even lower than environmental levels, changed thyroid weight and volume, with decreased T3 and T4 plasma levels $(216,217)$.

Overall, thyroid-disrupting chemicals are less investigated than estrogen or androgen disrupting compounds, thus very few studies have centered on investigating TH-related endpoints of pesticide mixtures.

\section{DISCUSSION}

\section{Evidence of PPP Thyroid Disrupting Effects}

A significant increase in many neurodevelopmental and neurodegenerative diseases in both adults and children has drawn attention to the potential role of environmental factors, including pesticides (218). Despite the relatively well-known effects of different classes of pesticides on the HPT axis (44, 219), numerous knowledge gaps and mechanistic insights remain between specific thyroid hormone-related endpoints and adverse neurodevelopmental parameters. In this review, after applying a defined methodology, we focused on 45 recent papers that investigated the association of $\mathrm{TH}$ disruption and pesticide exposure. A large number of these pesticides are associated with $\mathrm{TH}$ axis disruption either in humans or in experimental models.

\section{Epidemiological Data}

In most mother/child cohorts, organochlorine pesticides were associated with either an increase in TSH, a decrease in circulating $\mathrm{TH}$ or both (see section Background and Table 1). These pesticides represent the first generation and the majority is banned. However, as they are so persistent, they remain in human fluids and the environment as legacy pesticides, adding to the potential effects of newer pesticides. This second generation pesticides reviewed here, includes, the acetylcholine esterase inhibitors, includes organophosphates (including glyphosate and chlorpyrifos) and carbamates (sections Overview Of The Hypothalamus-Pituitary-Thyroid Axis and Methods). Their main mode of action causes the accumulation of acetylcholine at the synaptic region. Their presence in blood or urine during early development has been associated with thyroid dysfunction (114), increase of hypothyroidism $(91,139,140)$, brain function impairment $(107,113)$, and increase in hormone-dependent cancer (115), which can be related to homeostatic imbalance.

Interestingly, for the last generation of pesticides examined, only Fipronil belonging to the phenylpyrazole family was associated with a TSH decrease (189) in adults or a fT3 decrease level in newborns (169). No other associations were identified with pyrethroids or neonicotinoids despite several disruptive effects on the thyroid axis having been reported in in vivo animal studies, along with description of plausible mechanisms in vitro (see sections Pyrethroids, Phenylpyrazole, Neonicotinoids). However, the lack of epidemiological studies on $\mathrm{TH}$ and neonicotinoid exposure needs to be re-emphasized.

To understand the apparent discrepancy between epidemiological and animal models, some parameters need to be taken into account: (i) a major difference between previous and modern pesticide formulations is the shorter half-life and lower bio-accumulative potential of newer compounds. This implies that active compounds are not necessarily present at the time of sampling. (ii) If absent or below the detection limit, a specific biomarker or metabolite needs to be measured. In all cases, specific analytical methods need to be developed and validated. (iii) We are all exposed to a multitude of chemical and pesticide residues which are not necessarily measurable due to their short half-lives (see following section Underestimated Parameters in Epidemiological Studies). An example, although not a pesticide, is tetrabromobisphenol A(TBBPA) (220). Therefore, combined effects may not be apparent in epidemiological data whereas, in a more systematically controlled experiment, significant effects of a single compound or mixture may be revealed. Moreover, as we are exposed to a multiple of chemicals at a certain time point and geographical location, one has to be extremely cautious about associations made with any single chemical and on a given study population. To date, most data sets rely on basic biomarkers such as TH level measurements and too few studies investigate actual mixture effects.

\section{Underestimated Parameters in Epidemiological Studies}

(1) Joint exposures

Few epidemiological studies address mixture effects. This is because current risk assessment focuses on single molecules, with interactions between chemicals rarely taken into consideration. Mixture exposure, representing more realistic scenarios, is unduly underestimated.

First, legacy pesticides that have been overwhelmingly studied as single compounds are not considered as parts of mixtures we are currently exposed to. Second, synergy, commonly defined as the effect of multiple compounds working in combination that is greater than the expected additive effect of individual chemicals, is rarely considered (221). Further, EDCs can also exert opposing effects on the same axis and cross-talk between different axes has been well-established (222).

One of the principal aims of epidemiological studies is to clarify complex pictures. Thus, one goal is to determine if an association exists with the lowest occurring parameter. The effects of chemical exposure can be manifold, with pathways induced by banned, persistent or legacy PPP, potentially masking adverse health endpoints through overlapping and, possibly, overlooked mechanisms. Further, absence of association is not necessarily synonymous with chemical inertness.

(2) Long lasting effects and sensitization 
Pesticides may not exert an obvious adverse effect at the moment of exposure, but effects may be delayed or one exposure may sensitize the organism to a later occurrence, incurring a fitness cost, which might only be seen when a second stressor appears or later in life.

Different scenarios can be envisaged. The following examples may not refer specifically to pesticides but serve to illustrate the point. First, alterations of the immune system can be implicated. Recent studies revealed modifications in immune responses following exposure to a mixture of molecules used for fracking and found in drinking water. This has been shown in mouse and amphibian models following developmental exposure to a "fracking" mixture. Prior exposure resulted in increased mortality when the animals had to cope with an otherwise benign viral infection $(223,224)$. These altered immune responses echo epidemiological studies such as in the Faeroe islands reported by Grandjean and Andersen (225). They showed that children exposed to perfluorinated compounds displayed reduced antibody responses to a standard vaccination protocol.

Second, other environmental factors may act as secondary stressors, e.g., another xenobiotic affecting the same or another essential physiological pathway or the same xenobiotic at a different time-point, to which one can add climate change and/or reduced insect populations during bird migration. All of these parameters need to be borne in mind when attempting to understand the more far reaching effects of pesticides on non-target species, including humans.

\section{Evidence for in vivo and in vitro Mechanisms of Action}

One could summarize that organochlorine and organophosphates were designed to stably block enzymes used in the biochemical processes of the pest targeted. Most novel pesticides were designed to address problems of accumulation (most pronounced in compounds classified in the Stockholm convention as persistent organic pollutants (POPs), pesticideinduced pest resistance and high mammalian toxicity at low doses. In theory, these second generation molecules can be used at higher concentrations, as well as being more specific and biodegradable. However, their impact on non-target organisms are often neglected and only toxicity assays were (and still are) required before release on the market. As illustrated by the OP chlorpyrifos, pesticides may have cryptic effects at sub-lethal concentrations $(119,120,226)$.

All classes of pesticides have been associated with disruptive effects of the HPT axis at various levels determined by in vitro and/or in vivo studies (see Figure 2). Strikingly, none of these actions are currently included in assays required before a PPP is marketed. One must note that detection of disruption at a given level is insufficient to identify adverse action of all pesticides (even within different pesticide classes). While the abnormality might only be transient, persistence may be due to underlying thyroid dysfunction. More, as shown for OCPs, some chemicals may have opposite effects on circulating $\mathrm{TH}$. Interestingly in
Freire et al. (75), an endosulfan metabolite was associated with a decrease in TSH whereas other OCPs were associated with an increase in TSH. While in vivo studies suggest a mechanism based on increased clearance by hepatic activation of phase II enzymes, in vitro studies suggest direct action on $\mathrm{TH}$ synthesis at the thyroid gland level highlighting the complementarity of approaches.

Both the EFSA scientific report (44) on cumulative assessment groups of pesticides and annex $\mathrm{A}$ of the guidance document for the identification of EDCs, state that all molecules acting on the liver, increasing metabolism or modifying deiodinase 1 activity with consequent TH levels modifications, can be considered as $\mathrm{TH}$ axis-disrupting compounds. This feature represents a large proportion of pesticides and is a significant step toward identifying chemicals affecting the thyroid axis. Hence, pesticides may also exert effects beyond TH levels and the thyroid gland, with displacement from distributor protein and increased liver metabolism (e.g., fipronil-sulfone, see Figure 2 for a detailed review on level of actions of different pesticides on TH axis).

\section{A Need for Improved Testing Strategy, Risk Assessment, and Updated Legislation}

As Milner and Boyd already discussed in 2017, "pesticidovigilance" is something that needs to be developed. One of the possible strategies is to transpose what is currently carried out in pharmacovigilance for drugs, to PPPs or other classes of chemicals. This step would be beneficial for human, animal and environmental health (227).

\section{Improved Testing}

The vast majority of the available validated assays by EPA or OECD were developed from former reproductive or toxicological assays enriched with endocrine related endpoints, i.e., TH levels measurements and thyroid gland histology. Therefore, these assays were not specifically designed to detect endocrine sensitive or specific endpoints. The central nervous system is one of the major targets of $\mathrm{TH}$ and therefore, THaxis disruptors. Consequently, we sorely need better brain endpoints for potential effects of pesticide exposure taking into account the multiple levels of potential interference. In the brain, cell proliferation, neural stem cell differentiation, neuronal migration, synaptogenesis or myelination can all be influenced by $\mathrm{TH}$ availability. For example, in neonatal rats, prenatal exposure to the anti-thyroid compound PTU at low doses induces failure in neuronal migration-an event more sensitive than circulating $\mathrm{TH}$ levels (228). Given this overall lack of sensitivity, the EU commission is currently funding three large-scale projects (ATHENA, ERGO, and SCREENED) to develop innovative and specific endpoints for TH axis disruption, specifically with a focus on brain endpoints.

\section{Risk Assessment}

The report by Demeneix and Slama for the EU parliament in early 2019 highlighted the steps necessary for efficient risk management in terms of protecting Health and environment: 

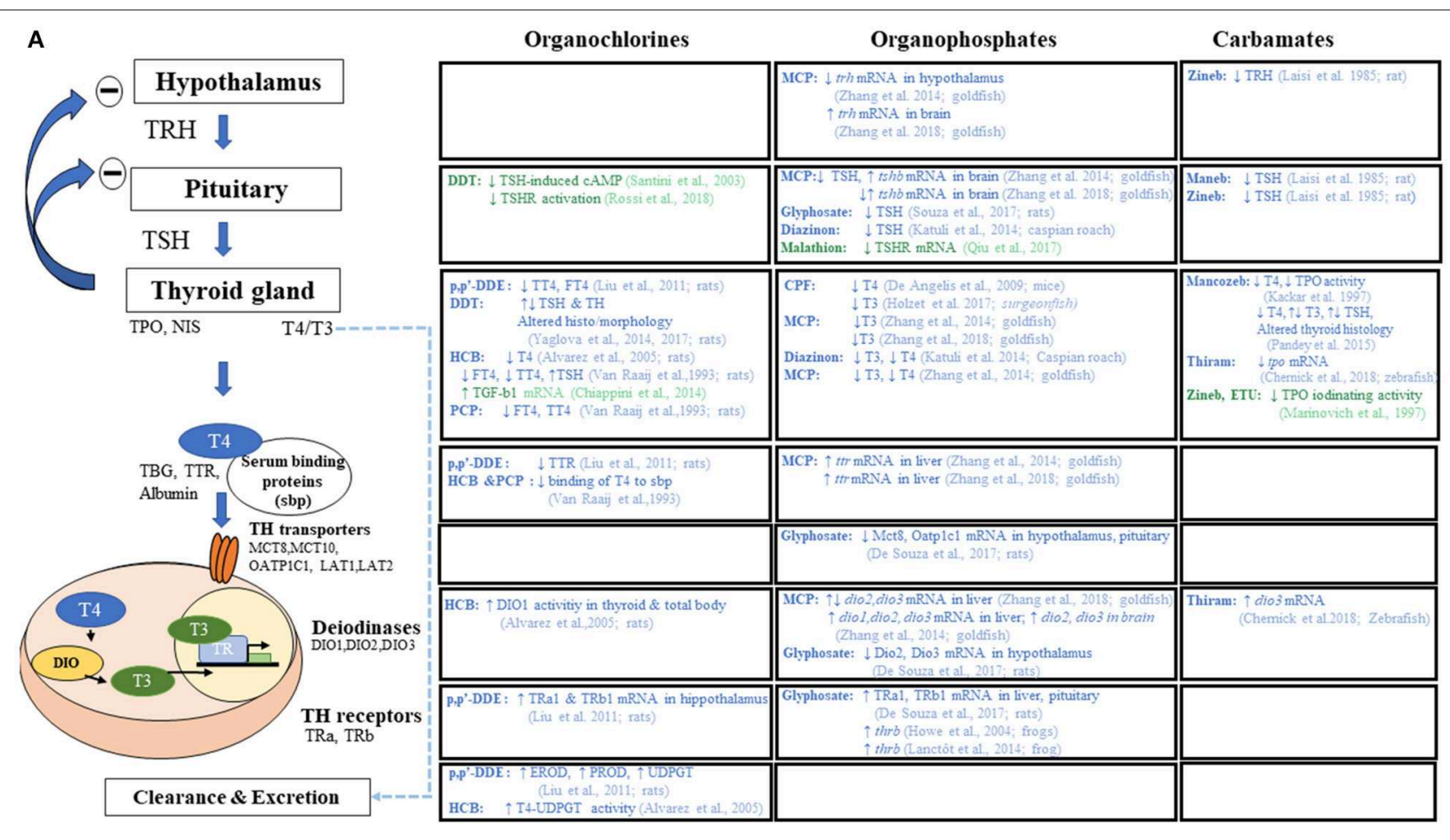

B

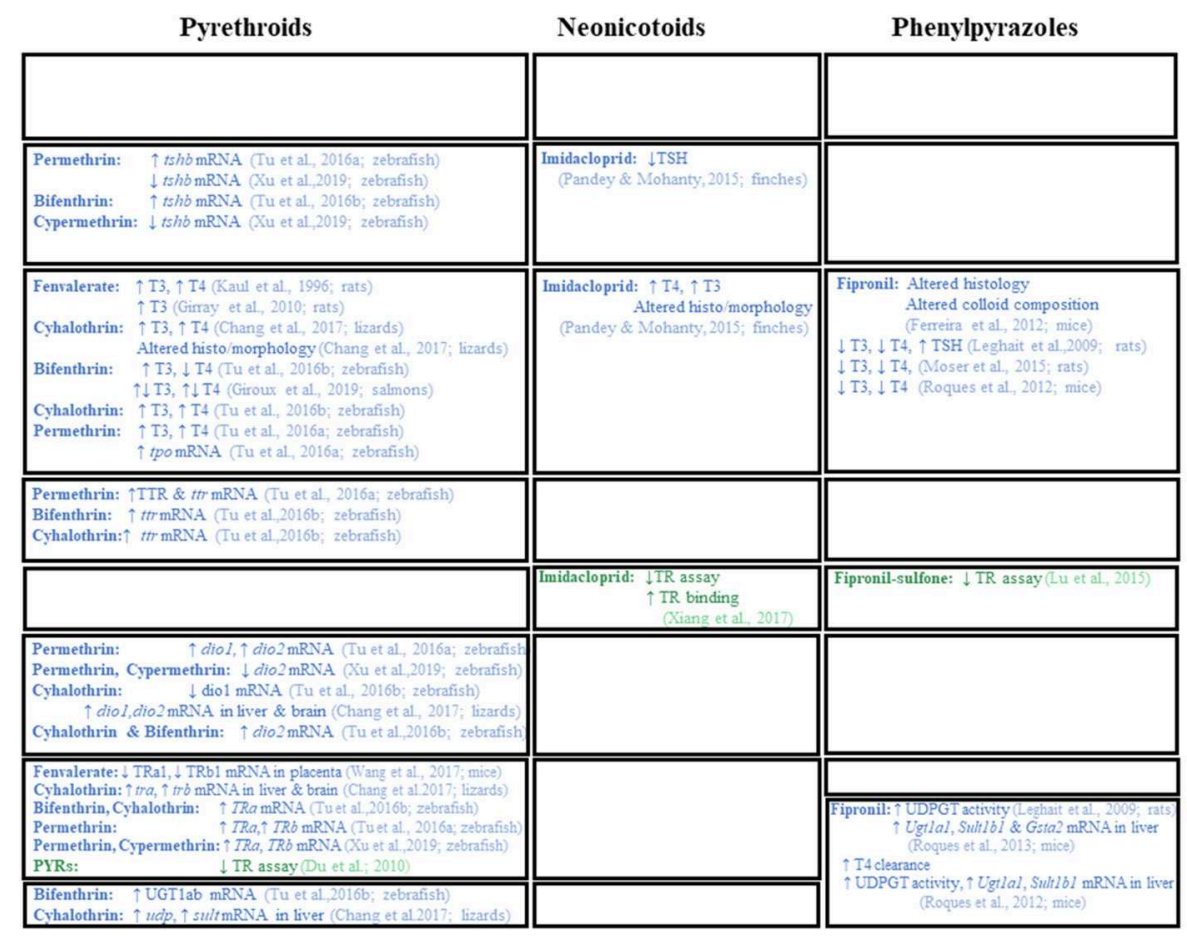

FIGURE 2 | Mode(s) of action of pesticides reported by in vivo (in blue) and in vitro (in green) articles. (A) Mode(s) of action of 1st and 2nd generation of pesticides (organocholorines, organophosphates, and carbamates). (B) Mode(s) of action of newer pesticide families (pyrethroids, neonicotinoids, and phenylpyrazoles). TRH, thyrotropin-releasing hormone; TSH, thyroid stimulating hormone; T4, thyroxine; T3, triiodothyronine; TPO, thyroperoxidase; NIS, sodium/iodide symporter; TBG, thyroxin binding globulin; TTR, transthyretin; MCT, monocarboxylate transporters (mct8, mct10); OATP1C1, organic anion-transporting polypeptide 1c1; LAT, large neutral amino acid transporter (lat1 and lat2); DIO, deiodinases (dio1, dio2, dio3); TR, thyroid hormone receptor (thra, thrb); UGT1ab, UDP-glucuronyltransferase 1ab; UDPGT, UDP-glucuronyltransferase; SULT, sulfotransferase; EROD, ethoxy-resorufin-O-deethylase; PROD, pentoxy-resorufin-O-deethylase; GSTA2, glutathione S-transferase alpha 2; cAMP, Cyclic adenosine monophosphate; TGF-b1, transforming growth factor b1; DDT, dichlorodiphenyl trichloroethane; $p, p^{\prime}$ DDE, p, $\mathrm{p}^{\prime}$-dichlorodiphenyl dichloroethylene; HCB, hexachlorobenzene; PCP, pentachlorophenol; MCP, monocrotophos; CPF, chlorpyrifos; ETU, ethylenethiourea. 
(1) a hazard definition followed by the (2) availability of a guidance document to allow reproducible application of the definition (3) specific validated assays (4) test requirements and (5) integration of the results in a risk management strategy (229). Only steps 1, 2 and 5 are fulfilled for PPPs. Current risk assessment cannot integrate specific endpoints and mixture effects, though innovative approaches have been developed to overcome these limitations for compounds other than pesticides (230).

\section{Legislation}

A definition for EDCs and criteria relative to PPP and biocides was adopted in 2018 in the EU. A guidance document on identification of endocrine disruptors for PPP and biocides was approved in June 2018 (231). Nevertheless, major gaps still exist in order to appropriately regulate PPP, essentially attributable to the current lack of specific endpoints. Recognition of the effects of mixtures is making progress as highlighted by EFSA submitting a document for public consultation on the establishment of cumulative assessment groups of pesticides for their effects on thyroid signaling (232).

\section{CONCLUSION}

The recent data reviewed here show that in humans, TSH, T3, and T4 measurements are still the most common endpoints evalutated in order to address thyroid disruption and pesticide exposure. Epidemiological data reveal that legacy pesticides (Organochlorine, organophosphate, carbamates) are more often associated with thyroid axis disruption than modern compounds (pyrethroids, neoinicotinoids, and phenylpyrazoles). However, experimental work demonstrates, with both in vivo and in vitro evidence, that each pesticide class disrupts thyroid homeostasis at different levels. Therefore, one should consider systematizing $\mathrm{TH}$ measurements, determining more sensitive brain endpoints for assessing $\mathrm{TH}$ disruption and carrying out more detailed longitudinal studies in epidemiology. As the OECD and the EU Commission have underlined, revisiting thyroid axis-disrupting chemicals is a major research priority.

\section{TAKE HOME MESSAGES}

- Multiple arguments link environmental causes to the increased incidence of neurodevelopmental disease that

\section{REFERENCES}

1. Costa LG. Toxicology of pesticides: a brief history. In: Toxicology of Pesticides. Berlin; Heidelberg: Springer (1987). p. 1-10. doi: 10.1007/978-3-642-70898-5_1

2. Carvalho FP. Pesticides, environment, and food safety. Food Energy Secur. (2017) 6:48-60. doi: 10.1002/ fes 3.108

3. Zhang W, Jiang F, Ou J. Global pesticide consumption and pollution: with China as a focus. Proc Int Acad Ecol Environ Sci. (2011) 1:125-44. Available online at: https://www.researchgate.net/publication/228841853_ Global_pesticide_consumption_and_pollution_With_China_as_a_focus many authors have suggested could be related to altered TH signaling.

- Experimental studies show that different classes of pesticides can act at multiple levels on TH signaling.

- Most often, data from epidemiological studies measure levels of TSH and/or TH in blood. These endpoints may not be sensitive enough to detect the small changes that might occur with newer pesticide formulations.

- Hence, there is a need for novel $\mathrm{TH}$ and brain specific endpoints that are more sensitive to variations in $\mathrm{TH}$.

- A final point is the need to take the mixture effects (of pesticides and other EDCs) into consideration in risk assessment and regulatory purposes.

\section{AUTHOR CONTRIBUTIONS}

ML and J-BF conceptualized and designed the study and conducted pre-screening on abstracts. ML, J-BF, and SC identified the Mesh terms. ML and SC enriched the Mesh Terms and reviewed all the articles and interpreted the data. ML drafted the figure. ML, SC, BD, and J-BF edited the manuscript. All authors read and approved the manuscript.

\section{FUNDING}

BD was employed by MNHN and J-BF by CNRS. ML is a Ph.D. student implicated in EU H2020 project-EDC-MixRisk ( ${ }^{\circ}$ 634880) and SC in EU H2020 HBM4EU ( $\left.{ }^{\circ} 733032\right)$. BD and JBF participate in H2020 ATHENA No. 825161 and ENDPOINTS No. 825759.

\section{ACKNOWLEDGMENTS}

We thank Rodrigo Senovilla for helping to perform the analysis and the according excel document (Supplemental Information).

\section{SUPPLEMENTARY MATERIAL}

The Supplementary Material for this article can be found online at: https://www.frontiersin.org/articles/10.3389/fendo. 2019.00743/full\#supplementary-material

Table S1 | All articles (223) classified by pesticide class with justification for selection or omission.

4. Food and Agriculture Organization of the United Nations (FAO). FAOSTAT. (2019). Available online at: http://www.fao.org/faostat/en/\#data/ RF (accessed April 9, 2019).

5. Costa LG. The neurotoxicity of organochlorine and pyrethroid pesticides. Handb Clin Neurol. (2015) 131:135-48. doi: 10.1016/B978-0-444-62627-1.00009-3

6. Yusa V, Millet M, Coscolla C, Roca M. Analytical methods for human biomonitoring of pesticides. A review. Anal Chim Acta. (2015) 891:15-31. doi: 10.1016/j.aca.2015.05.032

7. Köhler H, Triebskorn R. Wildlife ecotoxicology of pesticides: can we track effects to the population level and beyond? Science. (2013) 341:759-66. doi: 10.1126/science. 1237591 
8. Peakall DB, Lincer JL, Risebrough RW, Pritchard JB, Kinter WB. DDE-induced egg-shell thinning: Structural and physiological effects in three species. Comp Gen Pharmacol. (1973) 4:305-13. doi: 10.1016/0010-4035(73)90013-X

9. Ratcliffe DA. Changes attributable to pesticides in egg breakage frequency and eggshell thickness in some British birds. J Appl Ecol. (1970) 3:147-68. doi: $10.2307 / 2401998$

10. Colborn T. Clement C. Chemically-Induced Alterations in Sexual and Functional Development: The Wildlife/Human Connection, Volume 21, Advances in Modern Environmental Toxicology. Princeton, NJ: Princeton Scientific Publishing Co., Inc. (1992). Available online at: http://agris.fao.org/ agris- search/search.do?recordID=US9545328

11. Colborn T, Dumanoski D, Myers JP. Our Stolen Future?: Are We Threatening Our Fertility, Intelligence, and Survival? A Scientific Detective Story. (1996). European Commission. EU Pesticides Database - Fipronil. Available online at: http://ec.europa.eu/food/plant/pesticides/eu-pesticides-database/ public $/$ event $=$ activesubstance.detail\&language $=\mathrm{EN} \&$ selectedID $=1363$ (accessed April 10, 2019).

12. Alewu B, Nosiri C. Pesticides and human health. In: Pesticides in the Modern World - Effects of Pesticides Exposure. InTech. p. 303-14.

13. Lushchak VI, Matviishyn TM, Husak VV, Storey JM, Storey KB. Pesticide toxicity: a mechanistic approach. Excli J. (2018) 17:1101-36. doi: $10.17179 /$ excli2018-1710

14. Hutter H, Moshammer H. Pesticides are an occupational and public health issue. Int J Environ Res Public Health. (2018) 15:1650. doi: $10.3390 /$ ijerph15081650

15. Hill CE, Myers JP, Vandenberg LN. Nonmonotonic dose-response curves occur in dose ranges that are relevant to regulatory decision-making. Dose Response. (2018) 16:1559325818798282. doi: 10.1177/15593258187 98282

16. Vandenberg LN. Low-dose effects of hormones and endocrine disruptors. In: Vitamins and Hormones (Elsevier Inc.). p. 129-165. doi: 10.1016/B978-0-12-800095-3.00005-5

17. Mnif W, Ibn A, Hassine H, Bouaziz A, Bartegi A, Thomas O. Effect of endocrine disruptor pesticides: a review. Int $J$ Environ Res Public Health. (2011) 8:2265-303. doi: 10.3390/ijerph806 2265

18. Bretveld RW, Thomas CMG, Scheepers PTJ, Zielhuis GA, Roeleveld N. Pesticide exposure: The hormonal function of the female reproductive system disrupted? Reprod Biol Endocrinol. (2006) 4:1-14. doi: 10.1186/1477-7827-4-30

19. WHO. State-of-the-Science of Endocrine Disrupting Chemicals, 2012. United Nations Environment Programme and the World Health Organization, Geneva (2012).

20. Burggren WW, Mueller CA. Developmental critical windows and sensitive periods as three-dimensional constructs in time and space. Physiol Biochem Zool. (2015) 88:91-102. doi: 10.1086/679906

21. Fudvoye J, Bourguignon JP, Parent AS. Endocrine-disrupting chemicals and human growth and maturation: a focus on early critical windows of exposure. Vitam Horm. (2014) 94:1-25. doi: 10.1016/B978-0-12-800095-3.00001-8

22. Sohmer H, Freeman S. The importance of thyroid hormone for auditory development in the fetus and neonate. Audiol Neurotol. (1996) 1:137-47. doi: $10.1159 / 000259194$

23. Kadenbach B, Freund R, Barth J, Akgün R, Linder D, Goglia F. Regulation of electron transport and proton pumping of cytochrome $\mathrm{C}$ oxidase by nucleotides and thyroid hormones. Prog Cell Res. (1995) 5:19-23. doi: 10.1016/B978-0-444-82235-2.50008-4

24. Flamant F, Samarut J. Thyroid hormone receptors: lessons from knockout and knock-in mutant mice. Trends Endocrinol Metab. (2003) 14:85-90. doi: 10.1016/S1043-2760(02)00043-7

25. Tata JR. The road to nuclear receptors of thyroid hormone. Biochim Biophys Acta Gen Subj. (2013) 1830:3860-66. doi: 10.1016/j.bbagen.2012. 02.017

26. Köhrle J. Thyroid hormones and derivatives: endogenous thyroid hormones and their targets. In: Plateroti M, Samarut J, editors. Methods in Molecular Biology. Clifton, NJ: Springer protocols (2018), p. 85-104. doi: 10.1007/978-1-4939-7902-8_9
27. Bernal J. Thyroid hormone receptors in brain development and function. Nat Clin Pract Endocrinol Metab. (2007) 3:249-59. doi: 10.1038/ncpendmet0424

28. Korevaar TIM, Muetzel R, Medici M, Chaker L, Jaddoe VWV, de Rijke YB, et al. Association of maternal thyroid function during early pregnancy with offspring IQ and brain morphology in childhood: A populationbased prospective cohort study. Lancet Diabetes Endocrinol. (2016) 4:35-43. doi: 10.1016/S2213-8587(15)00327-7

29. Bellanger M, Demeneix B, Grandjean P, Zoeller RT, Trasande L. Neurobehavioral deficits, diseases, and associated costs of exposure to endocrine-disrupting chemicals in the European Union. $J$ Clin Endocrinol Metab. (2015) 100:1256-66. doi: 10.1210/jc.20144323

30. Sellitti DF, Suzuki K. Intrinsic regulation of thyroid function by thyroglobulin. Thyroid. (2013) 24:625-38. doi: 10.1089/thy.2013.0344

31. Rousset B, Dupuy C, Miot F, Dumont J. Chapter 2: thyroid hormone synthesis and secretion. In: Feingold KR, Anawalt B, Boyce A, et al., editors. Endotext. Dartmouth, MA: MDText.com, Inc. (2015).

32. Hagenbuch B. Cellular entry of thyroid hormones by organic anion transporting polypeptides. Best Pract Res Clin Endocrinol Metab. (2007) 21:209-21. doi: 10.1016/j.beem.2007.03.004

33. van der Deure WM, Peeters RP, Visser TJ. Molecular aspects of thyroid hormone transporters, including MCT8, MCT10, and OATPs, and the effects of genetic variation in these transporters. J Mol Endocrinol. (2010) 44:1-11. doi: 10.1677/JME-09-0042

34. Luongo C, Dentice M, Salvatore D. Deiodinases and their intricate role in thyroid hormone homeostasis. Nat Rev Endocrinol. (2019) 15:479-88. doi: 10.1038/s41574-019-0218-2

35. Hönes GS, Rakov H, Logan J, Liao XH, Werbenko E, Pollard AS, et al. Noncanonical thyroid hormone signaling mediates cardiometabolic effects in vivo. Proc Natl Acad Sci USA. (2017) 114:E11323-32. doi: 10.1073/pnas.1706801115

36. Guissouma H, Dupré SM, Becker N, Jeannin E, Seugnet I, Desvergne $\mathrm{B}$, et al. Feedback on hypothalamic TRH transcription is dependent on thyroid hormone receptor N terminus. Mol Endocrinol. (2002) 16:1652-66. doi: 10.1210/mend.16.7.0868

37. Lezoualc'h F, Seugnet I, Monnier AL, Ghysdael J, Behr J-P, Demeneix BA. Inhibition of neurogenic precursor proliferation by antisense thyroid hormone receptor oligonucleotides. J Biol Chem. (1995) 270:12100-8. doi: $10.1074 /$ jbc.270.20.12100

38. Koulouri O, Gurnell M. How to interpret thyroid function tests. Clin Med. (2013) 13:282-6. doi: 10.7861/clinmedicine.13-3-282

39. Koulouri O, Moran C, Halsall D, Chatterjee K, Gurnell M. Pitfalls in the measurement and interpretation of thyroid function tests. Best Pract Res Clin Endocrinol Metab. (2013) 27:745-62. doi: 10.1016/j.beem.2013. 10.003

40. Schneider C, Feller M, Bauer DC, Collet TH, da Costa BR, Auer R, et al. Initial evaluation of thyroid dysfunction - Are simultaneous TSH and fT4 tests necessary? PLoS ONE. (2018) 13:e0196631. doi: 10.1371/journal.pone.0196631

41. Boas M, Feldt-rasmussen U, Main KM. Molecular and cellular endocrinology thyroid effects of endocrine disrupting chemicals. Mol Cell Endocrinol. (2012) 355:240-8. doi: 10.1016/j.mce.2011.09.005

42. Crofton KM, Foss JA, Hass U, Jensen KF, Levin ED, Parker SP. Undertaking positive control studies as part of developmental neurotoxicity testing A report from the ILSI Research Foundation/Risk Science Institute expert working group on neurodevelopmental endpoints. Neurotoxicol Teratol. (2008) 30:266-87. doi: 10.1016/j.ntt.2007.06.002

43. Diamanti-Kandarakis E, Bourguignon JP, Giudice LC, Hauser R, Prins GS, Soto AM, et al. Endocrine-disrupting chemicals: an Endocrine Society scientific statement. Endocr Rev. (2009) 30:293-342. doi: 10.1210/er.2009-0002

44. European Food Safety Authority (EFSA). Scientific Opinion on the identification of pesticides to be included in cumulative assessment groups on the basis of their toxicological profile. EFSA J. (2013) 11:3293. doi: 10.2903/sp.efsa.2014.EN-538

45. Brouwer A, Morse DC, Lans MC, Gerlienke Schuur A, Murk AJ, KlassonWehler E, et al. Interactions of persistent environmental organohalogens with the thyroid hormone system: mechanisms and possible consequences 
for animal and human health. Toxicol Ind Health. (1998) 14:59-84. doi: $10.1177 / 074823379801400107$

46. Mughal BB, Fini JB, Demeneix BA. Thyroid-disrupting chemicals and brain development: an update. Endocr Connect. (2018) 7:R160-86. doi: 10.1530/EC-18-0029

47. Calsolaro V, Pasqualetti G, Niccolai F, Caraccio N, Monzani F. Thyroid disrupting chemicals. Int J Mol Sci. (2017) 18:1-17. doi: 10.3390/ijms18122583

48. Goldner WS, Sandler DP, Yu F, Hoppin JA, Kamel F, Levan TD. Pesticide use and thyroid disease among women in the Agricultural Health Study. Am J Epidemiol. (2010) 171:455-64. doi: 10.1093/aje/kwp404

49. Goldner WS, Sandler DP, Yu F, Shostrom V, Hoppin JA, Kamel F, et al. Hypothyroidism and pesticide use among male private pesticide applicators in the agricultural health study. J Occup Environ Med. (2013) 55:1171-8. doi: 10.1097/JOM.0b013e31829b290b

50. Dart RC. Medical Toxicology. 3rd ed. Philadelphia PA: Lippincott, Williams \& Wilkins (2004). Available online at: https://trove.nla.gov.au/work/28755027? q\&versionId $=45741058$

51. Gupta RC, Milatovic D. Insecticides. In: Gupta RC, editor. Biomarkers in Toxicology. Elsevier. p. 389-407. doi: 10.1016/B978-0-12-404630-6.00023-3 Available online at: https://books.google.be/books?id= EMpUAgAAQBAJ\&pg=PA389\&lpg=PA389\&dq=10.1016/B978$0-12-404630-6.00023-3 \&$ source $=$ bl\&ots $=$ MhpFshKVLd\&sig $=$ ACfU3U2rwep4CmgbQmWJ-JdAH9iFhdTgaA\&hl=nl\&sa=X\&ved= 2ahUKEwif4ZHesdrlAhUBJlAKHTgBCssQ6AEwAXoECAkQAQ\#v= onepage \&q $=10.1016 \% 2 \mathrm{FB} 978-0-12-404630-6.00023-3 \& \mathrm{f}=$ false

52. Hainzl D, Burhenne J, Parlar H. Theoretical consideration of the structural variety in the toxaphene mixture taking into account recent experimental results. Chemosphere. (1994) 28:245-52. doi: 10.1016/0045-6535(94) 90121-X

53. Pleština R. Pesticides and herbicides|types of pesticide. In: Trugo L, Finglas PM, editors. Encyclopedia of Food Sciences and Nutrition. Baltimore, MD: Johns Hopkins University, Center for Human Nutrition, School of Hygiene and Public Health; Elsevier. p. 4473-4483. doi: 10.1016/B0-12-227055-X/00909-3 Available online at: https://www. sciencedirect.com/referencework/9780122270550/encyclopedia- of-foodsciences-and-nutrition\#book-description

54. US EPA. DDT - A Brief History and Status. (2012) Available online at: https:// www.epa.gov/ingredients- used-pesticide-products/ddt-brief-history-andstatus

55. Davidson B, Soodak M, Strout HV, Neary JT, Nakamura C, Maloof F. Thiourea and cyanamide as inhibitors of thyroid peroxidase: the role of iodide*. Endocrinology. (1979) 104:919-24. doi: 10.1210/endo-104-4-919

56. Carson R, Darling L, Darling L. Silent Spring. Boston, MA; Cambridge, MA: Houghton Mifflin Company; The Riverside Press (1962). Available online at: https://www.worldcat.org/title/silent-spring/oclc/561302

57. United Nations Environment Programme. Stockholm Convention. The 12 Initial POPs. Available online at: http://chm.pops.int/TheConvention/ ThePOPs/The12InitialPOPs/tabid/296/Default.aspx

58. Rogan WJ, Chen A. Health risks and benefits of bis(4chlorophenyl)-1,1,1-trichloroethane (DDT). Lancet. (2005)763-73. doi: 10.1016/S0140-6736(05)67182-6

59. Dietz R, Riget F, Cleemann M, Aarkrog A, Johansen P. Comparison of contaminants from different trophic levels and ecosystems. (2000) 245:22131. doi: 10.1016/S0048-9697(99)00447-7

60. Puertas R, Lopez-Espinosa MJ, Cruz F, Ramos R, Freire C, Pérez-García M, et al. Prenatal exposure to mirex impairs neurodevelopment at age of 4 years. Neurotoxicology. (2010) 31:154-60. doi: 10.1016/j.neuro.2009.09.009

61. Torres-Sánchez L, Rothenberg SJ, Schnaas L, Cebrián ME, Osorio E, Carmen Hernández $\mathrm{M}$, et al. In utero $\mathrm{p}, \mathrm{p}^{\prime}$-DDE exposure and infant neurodevelopment-a perinatal cohort in Mexico. Environ Health Perspect. (2007) 115:435-9. doi: 10.1289/ehp.9566

62. Gaspar FW, Harley KG, Kogut K, Chevrier J, Maria A, Sjödin A, et al. Prenatal DDT and DDE exposure and child IQ in the CHAMACOS cohort. Environ Int. (2015) 85:206-12. doi: 10.1016/j.envint.2015.09.004

63. Agency for Toxic Substances and Disease Registry (ATSDR). Toxicological Profile for DDT, DDE, and DDD. (2002). Available online at: https://www. atsdr.cdc.gov/toxprofiles/tp35.pdf (accessed April 12, 2019).
64. Berghuis SA, Bos AF, Sauer PJ, Roze E. Developmental neurotoxicity of persistent organic pollutants: an update on childhood outcome. Arch Toxicol. (2015) 89:687-709. doi: 10.1007/s00204-015-1463-3

65. Roze E, Meijer L, Bakker A, Van Braeckel KNJA, Sauer PJJ, Bos AF. Prenatal exposure to organohalogens, including brominated flame retardants, influences motor, cognitive, and behavioral performance at school age. Environ Health Perspect. (2009) 117:1953-8. doi: 10.1289/ehp.0901015

66. Torres-Sánchez L, Schnaas L, Cebrián ME, Hernández MC, Valencia EO, García Hernández RM, et al. Prenatal dichlorodiphenyldichloroethylene (DDE) exposure and neurodevelopment: A follow-up from 12 to 30 months of age. Neurotoxicology. (2009) 30:1162-5. doi: 10.1016/j.neuro.2009. 08.010

67. Sagiv SK, Thurston SW, Bellinger DC, Tolbert PE, Altshul LM, Korrick SA. Prenatal organochlorine exposure and behaviors associated with attention deficit hyperactivity disorder in school-aged children. Am J Epidemiol. (2010) 171:593-601. doi: 10.1093/aje/kwp427

68. Ribas-Fitó N, Torrent M, Carrizo D, Júlvez J, Grimalt JO, Sunyer J. Exposure to hexachlorobenzene during pregnancy and children's social behavior at 4 years of age. Environ Health Perspect. (2007) 115:447-50. doi: 10.1289/ehp. 9314

69. Sioen I, Den Hond E, Nelen V, Van de Mieroop E, Croes K, Van Larebeke N, et al. Prenatal exposure to environmental contaminants and behavioural problems at age $7-8$ years. Environ Int. (2013) 59:225-31. doi: 10.1016/j.envint.2013.06.014

70. Alvarez-Pedrerol M, Carrizo D, Grimalt JO, Sunyer J. Effects of PCBs, p, p'DDT, $\mathrm{p}, \mathrm{p}^{\prime}-\mathrm{DDE}, \mathrm{HCB}$ and $\beta-\mathrm{HCH}$ on thyroid function in preschool children. Occup Environ Med. (2008) 65:452-7. doi: 10.1136/oem.2007.032763

71. Asawasinsopon R, Prapamontol T, Prakobvitayakit O, Vaneesorn Y. The association between organochlorine and thyroid hormone levels in cord serum: a study from northern Thailand. Environ Int. (2006) 32:554-9. doi: 10.1016/j.envint.2006.01.001

72. Lopez-Espinosa MJ, Vizcaino E, Murcia M, Fuentes V, Garcia AM, Rebagliato $M$, et al. Prenatal exposure to organochlorine compounds and neonatal thyroid stimulating hormone levels. J Expo Sci Environ Epidemiol. (2009) 20:579-88. doi: 10.1038/jes.2009.47

73. Ribas-Fitó N, Sala M, Cardo E, Mazón C, De Muga ME, Verdú A, et al. Organochlorine compounds and concentrations of thyroid stimulating hormone in newborns. Occup Environ Med. (2003) 60:301-3. doi: 10.1136/oem.60.4.301

74. Dallaire R, Dewailly É, Ayotte P, Muckle G, Laliberté C, Bruneau S. Effects of prenatal exposure to organochlorines on thyroid hormone status in newborns from two remote coastal regions in Québec, Canada. Environ Res. (2008) 108:387-92. doi: 10.1016/j.envres.2008.08.004

75. Freire C, Lopez-espinosa M, Fernández M, Molina-molina J. Science of the total environment prenatal exposure to organochlorine pesticides and TSH status in newborns from. Sci Total Environ. (2011) 409:3281-7. doi: 10.1016/j.scitotenv.2011.05.037

76. Kim S, Park J, Kim HJ, Lee JJ, Choi G, Choi S, et al. Association between several persistent organic pollutants and thyroid hormone levels in cord blood serum and bloodspot of the newborn infants of Korea. PLoS ONE. (2015) 10:e0125213. doi: 10.1371/journal.pone.0125213

77. Luo $\mathrm{D}, \mathrm{Pu} \mathrm{Y}$, Tian $\mathrm{H}, \mathrm{Wu} \mathrm{W}$, Sun $\mathrm{X}$, Zhou T, et al. Association of in utero exposure to organochlorine pesticides with thyroid hormone levels in cord blood of newborns. Environ Pollut. (2017) 231:78-86. doi: 10.1016/j.envpol.2017.07.091

78. Takser L, Mergler D, Baldwin M, de Grosbois S, Smargiassi A, Lafond J. Thyroid hormones in pregnancy in relation to environmental exposure to organochlorine compounds and mercury. Environ Health Perspect. (2005) 113:1039-45. doi: 10.1289/ehp.7685

79. Maervoet J, Vermeir G, Covaci A, Van Larebeke N, Koppen G, Schoeters $\mathrm{G}$, et al. Association of thyroid hormone concentrations with levels of organochlorine compounds in cord blood of neonates. Environ Health Perspect. (2007) 115:1780-6. doi: 10.1289/ehp.10486

80. Cordier S, Bouquet E, Warembourg C, Massart C, Rouget F, Kadhel $\mathrm{P}$, et al. Perinatal exposure to chlordecone, thyroid hormone status and neu- rodevelopment in infants: The Timoun cohort study in Guadeloupe (French West Indies). Environ Res. (2015) 138:271-8. doi: 10.1016/j.envres.2015.02.021 
81. Dufour P, Pirard C, Seghaye MC, Charlier C. Association between organohalogenated pollutants in cord blood and thyroid function in newborns and mothers from Belgian population. Environ Pollut. (2018) 238:389-96. doi: 10.1016/j.envpol.2018.03.058

82. Lopez-Espinosa MJ, Vizcaino E, Murcia M, Llop S, Espada M, Seco V, et al. Association between thyroid hormone levels and 4,4'-DDE concentrations in pregnant women (Valencia, Spain). Environ Res. (2009) 109:479-85. doi: $10.1016 /$ j.envres.2009.02.003

83. Li ZM, Hernandez-Moreno D, Main KM, Skakkebæk NE, Kiviranta H, Toppari J, et al. Association of in utero persistent organic pollutant exposure with placental thyroid hormones. Endocrinology. (2018) 159:347381. doi: 10.1210/en.2018-00542

84. Meeker JD, Altshul L, Hauser R. Serum PCBs p,p'-DDE and HCB predict thyroid hormone levels in men. Environ Res. (2007) 104:296-304. doi: 10.1016/j.envres.2006.11.007

85. Bloom MS, Jansing RL, Kannan K, Rej R, Fitzgerald EF. Thyroid hormones are associated with exposure to persistent organic pollutants in aging residents of upper Hudson River communities. Int J Hyg Environ Health. (2015) 217:473-82. doi: 10.1016/j.ijheh.2013.09.003

86. Blanco-muñoz J, Lacasaña $\mathrm{M}$, López-flores I, Rodríguez-barranco $\mathrm{M}$, González-alzaga B, Bassol S, et al. Association between organochlorine pesticide exposure and thyroid hormones in floriculture workers. Environ Res. (2016) 150:357-63. doi: 10.1016/j.envres.2016.05.054

87. Rathore M, Bhatnagar P, Mathur D, Saxena GN. Burden of organochlorine pesticides in blood and its effect on thyroid hormones in women. Sci Total Environ. (2002) 295:207-15. doi: 10.1016/S0048-9697(02)00094-3

88. Rylander L, Wallin E, Jönssson BA, Stridsberg M, Erfurth EM, Hagmar L. Associations between CB-153 and p, $\mathrm{p}^{\prime}$-DDE and hormone levels in serum in middle-aged and elderly men. Chemosphere. (2006) 65:375-81. doi: 10.1016/j.chemosphere.2006.02.012

89. Schell LM, Gallo MV, Denham M, Ravenscroft J, DeCaprio AP, Carpenter DO. Relationship of thyroid hormone levels to levels of polychlorinated biphenyls, lead, p,p'-DDE, and other toxicants in Akwesasne Mohawk Youth. Environ Health Perspect. (2008) 116:806-13. doi: 10.1289/ehp.10490

90. Piccoli C, Cremonese C, Koifman RJ, Koifman S, Freire C. Pesticide exposure and thyroid function in an agricultural population in Brazil. Environ Res. (2016) 151:389-98. doi: 10.1016/j.envres.2016.08.011

91. Shrestha S, Parks CG, Goldner WS, Kamel F, Umbach DM, Ward MH, et al. Pesticide use and incident hypothyroidism in pesticide applicators in the Agricultural Health Study. Environ Health Perspect. (2018) 126:97008. doi: 10.1289/EHP3194

92. Lerro CC, Beane Freeman LE, DellaValle CT, Kibriya MG, AschebrookKilfoy B, Jasmine F, et al. Occupational pesticide exposure and subclinical hypothyroidism among male pesticide applicators. Occup Environ Med. (2018) 75:79-89. doi: 10.1136/oemed-2017-104431

93. Turyk ME, Anderson HA, Persky VW. Relationships of thyroid hormones with polychlorinated biphenyls, dioxins, furans, and DDE in adults. Environ Health Perspect. (2007) 115:1197-203. doi: 10.1289/ehp. 10179

94. Liu C, Shi Y, Li H, Wang Y, Yang K. p,p'-DDE disturbs the homeostasis of thyroid hormones via thyroid hormone receptors, transthyretin, and hepatic enzymes. Horm Metab Res. (2011) 43:391-6. doi: 10.1055/s-00311277135

95. Langer P. The impacts of organochlorines and other persistent pollutants on thyroid and metabolic health. Front Neuroendocrinol. (2010) 31:497-518. doi: 10.1016/j.yfrne.2010.08.001

96. Yaglova NV, Yaglov VV. Changes in thyroid status of rats after prolonged exposure to low dose dichlorodiphenyltrichloroethane. Bull Exp Biol Med. (2014) 156:760-2. doi: 10.1007/s10517-014-2443-y

97. Yaglova NV, Yaglov VV. Cytophysiological changes in the follicular epithelium of the thyroid gland after long-term exposure to low doses of dichlorodiphenyltrichloroethane (DDT). Bull Exp Biol Med. (2017) 162:699702. doi: 10.1007/s10517-017-3691-4

98. Alvarez L, Hernández S, Martinez-de-Mena R, Kolliker-Frers R, Obregón MJ, Kleiman de Pisarev DL. The role of type I and type II $5^{\prime}$ deiodinases on hexachlorobenzene-induced alteration of the hormonal thyroid status. Toxicology. (2005) 207:349-62. doi: 10.1016/j.tox.2004. 10.006
99. van Raaij JA, Frijters CM, van den Berg KJ. Hexachlorobenzeneinduced hypothyroidism. Involvement of different mechanisms by parent compound and metabolite. Biochem Pharmacol. (1993) 46:1385-91. doi: 10.1016/0006-2952(93)90103-4

100. Starek-Świechowicz B, Budziszewska B, Starek A. Hexachlorobenzene as a persistent organic pollutant: Toxicity and molecular mechanism of action. Pharmacol Rep. (2017) 69:1232-9. doi: 10.1016/j.pharep.2017.06.013

101. Santini F, Vitti P, Ceccarini G, Mammoli C, Rosellini V, Pelosini C, et al. In vitro assay of thyroid disruptors affecting TSH-stimulated adenylate cyclase activity. J Endocrinol Invest. (2003) 26:950-5. doi: $10.1007 /$ BF03348190

102. Rossi M, Dimida A, Dell'anno MT, Trincavelli ML, Agretti P, Giorgi F, et al. The thyroid disruptor 1,1,1-trichloro-2,2-bis(p-chlorophenyl)-ethane appears to be an uncompetitive inverse agonist for the thyrotropin receptor. J Pharmacol Exp Ther. (2006) 320:465-74. doi: 10.1124/jpet.106.113613

103. Rossi M, Taddei AR, Fasciani I, Maggio R, Giorgi F. The cell biology of the thyroid-disrupting mechanism of dichlorodiphenyltrichloroethane (DDT). $J$ Endocrinol Invest. (2018) 41:67-73. doi: 10.1007/s40618-017-0716-9

104. Chiappini F, Pontillo C, Randi A, Alvarez L, Kleiman de Pisarev DL. Hexachlorobenzene induces TGF- $\beta 1$ expression, which is a regulator of p27 and cyclin D1 modifications. Toxicol Lett. (2014) 230:1-9. doi: $10.1016 /$ j.toxlet.2014.08.002

105. Nicolussi A, D'Inzeo S, Santulli M, Colletta G, Coppa A. TGF- $\beta$ control of rat thyroid follicular cells differentiation. Mol Cell Endocrinol. (2003) 207:1-11. doi: 10.1016/S0303-7207(03)00238-7

106. Vale A. Organophosphorus insecticide poisoning. BMJ Clin Evid. (2015) 2015:2102.

107. Rauh VA, Whyatt RM, Perera FP, Horton MK, Hao X, Barr DB, et al. Brain anomalies in children exposed prenatally to a common organophosphate pesticide. Proc Natl Acad Sci USA. (2012) 109:7871-6. doi: 10.1073/pnas.1203396109

108. Qiao D, Seidler FJ, Padilla S, Slotkin TA. Developmental neurotoxicity of chlorpyrifos: What is the vulnerable period? Environ Health Perspect. (2002) 110:1097-103. doi: 10.1289/ehp.021101097

109. Trasande L. When enough data are not enough to enact policy: The failure to ban chlorpyrifos. PLoS Biol. (2017) 15:e2003671. doi: 10.1371/journal.pbio.2003671

110. Margariti MG, Tsakalof AK, Tsatsakis AM. Analytical methods of biological monitoring for exposure to pesticides: recent update. Ther Drug Monit. (2007) 29:150-63. doi: 10.1097/FTD.0b013e31803d3509

111. Barr DB, Bravo R, Weerasekera G, Caltabiano LM, Whitehead RD, Olsson AO, et al. Concentrations of dialkyl phosphate metabolites of organophosphorus pesticides in the U.S. population. Environ Health Perspect. (2004) 112:186-200. doi: 10.1289/ehp.6503

112. Spaan S, Pronk A, Koch HM, Jusko TA, Jaddoe VWV, Shaw PA, et al. Reliability of concentrations of organophosphate pesticide metabolites in serial urine specimens from pregnancy in the Generation R Study. J Expo Sci Environ Epidemiol. (2015) 25:286-94. doi: 10.1038/jes.2014.81

113. Bouchard MF, Kogut K, Barr DB, Eskenazi B, Bradman A, Vedar $M$, et al. Prenatal exposure to organophosphate pesticides and IQ in 7-year-old children. Environ Health Perspect. (2011) 119:1189-95. doi: 10.1289/ehp.1003185

114. Suhartono S, Kartini A, Subagio HW, Budiyono B, Utari A, Suratman S, et al. Pesticide exposure and thyroid function in elementary school children living in an agricultural area, Brebes District, Indonesia. Int J Occup Environ Med. (2018) 9:137-44. doi: 10.15171/ijoem.2018.1207

115. Lerro CC, Koutros S, Andreotti G, Friesen MC, Alavanja MC, Blair A, et al. Organophosphate insecticide use and cancer incidence among spouses of pesticide applicators in the Agricultural Health Study. Occup Environ Med. (2015) 72:736-44. doi: 10.1136/oemed-2014-102798

116. Wang Y, Chen L, Wang C, Hum Y, Gao Y, Zhou Y, et al. Association between organophosphate pesticide exposure and thyroid hormones in pregnant women. Epidemiology. (2017) 28(Suppl. 1):S35-40. doi: 10.1097/EDE.0000000000000721

117. De Angelis S, Tassinari R, Maranghi F, Eusepi A, Di Virgilio A, Chiarotti F, et al. Developmental exposure to chlorpyrifos induces alterations in thyroid and thyroid hormone levels without other toxicity signs in CD-1 mice. Toxicol Sci. (2009) 108:311-9. doi: 10.1093/toxsci/kfp017 
118. Wilson NK, Chuang JC, Lyu C, Menton R, Morgan MK. Aggregate exposures of nine preschool children to persistent organic pollutants at day care and at home. J Expo Anal Environ Epidemiol. (2003) 13:187-202. doi: 10.1038/sj.jea.7500270

119. Mie A, Rudén C, Grandjean P. Safety of Safety Evaluation of Pesticides: developmental neurotoxicity of chlorpyrifos and chlorpyrifosmethyl. Environ Health. (2018) 17:77. doi: 10.1186/s12940-018$0421-y$

120. Holzer G, Besson M, Lambert A, Francois L, Barth P, Gillet B, et al. Fish larval recruitment to reefs is a thyroid hormone-mediated metamorphosis sensitive to the pesticide chlorpyrifos. Elife. (2017) 6:e27595. doi: 10.7554/eLife. 27595

121. Zhang $\mathrm{X}$, Tian $\mathrm{H}$, Wang $\mathrm{W}, \mathrm{Ru}$ S. Monocrotophos pesticide decreases the plasma levels of total 3,3,5-triiodo-l-thyronine and alters the expression of genes associated with the thyroidal axis in female goldfish (Carassius auratus). PLoS ONE. (2014) 9:e108972. doi: 10.1371/journal.pone. 0108972

122. Zhang X, Liu W, Wang J, Tian H, Wang W, Ru S. Quantitative analysis of in-vivo responses of reproductive and thyroid endpoints in male goldfish exposed to monocrotophos pesticide. Comp Biochem Physiol C Toxicol Pharmacol. (2018) 211:41-7. doi: 10.1016/j.cbpc.2018.05.010

123. Katuli KK, Amiri BM, Massarsky A, Yelghi S. Impact of a shortterm diazinon exposure on the osmoregulation potentiality of Caspian roach (Rutilus rutilus) fingerlings. Chemosphere. (2014) 108:396-404. doi: 10.1016/j.chemosphere.2014.02.038

124. Ortiz-Delgado JB, Funes V, Sarasquete C. The organophosphate pesticide -OP- malathion inducing thyroidal disruptions and failures in the metamorphosis of the Senegalese sole, Solea senegalensis. BMC Vet Res. (2019) 15:57. doi: 10.1186/s12917-019-1786-Z

125. Qiu Y, Xiong J, Zhang H, Tian L, Wu M, Wang J, Sun D. Evaluation on the thyroid disrupting mechanism of malathion in Fischer rat thyroid follicular cell line FRTL-5. Drug Chem Toxicol. (2017) 41:501-8. doi: 10.1080/01480545.2017.1397162

126. D’Angelo F, De Felice M, Iolascon A, Porreca I, Ceccarelli M, Ravo M, et al. Pesticide toxicogenomics across scales: in vitro transcriptome predicts mechanisms and outcomes of exposure in vivo. Sci Rep. (2016) 6:1-11. doi: $10.1038 /$ srep38131

127. Amrhein N, Deus B, Gehrke P, Steinrücken HC. The site of the inhibition of the shikimate pathway by glyphosate. Plant Physiol. (1980) 66:830-4. doi: 10.1104/pp.66.5.830

128. Herrmann K, Physiol P, Mol P, Downloaded B, Herrmann KM, Weaver LM. The shikimate pathway. Annu plant Physiol. (1999) 50:473-503. doi: 10.1146/annurev.arplant.50.1.473

129. Benbrook CM. Trends in glyphosate herbicide use in the United States and globally. Environ Sci Eur. (2016) 28:3. doi: 10.1186/s12302-0160070-0

130. Vencill WK. Herbicide Handbook. 8th ed. Lawrence, KS: Weed Science Society of America (2002). Available online at: https://www.worldcat.org/ title/herbicide-handbook/oclc/50099603

131. de Souza JS, Kizys MML, da Conceicao RR, Glebocki G, Romano RM, Ortiga-Carvalho TM, et al. Perinatal exposure to glyphosate-based herbicide alters the thyrotrophic axis and causes thyroid hormone homeostasis imbalance in male rats. Toxicology. (2017) 377:25-37. doi: 10.1016/j.tox.2016.11.005

132. Howe CM, Berrill M, Pauli BD, Helbing CC, Werry K, Veldhoen N. Toxicity of glyphosate-based pesticides to four north American frog species. Environ Toxicol Chem. (2004) 23:1928-38. doi: 10.1897/03-71

133. Lanctot C, Navarro-Martin L, Robertson C, Park B, Jackman P, Pauli BD, et al. Effects of glyphosate-based herbicides on survival, development, growth and sex ratios of wood frog (Lithobates sylvaticus) tadpoles. II: agriculturally relevant exposures to Roundup WeatherMax(R) and Vision(R) under laboratory conditions. Aquat Toxicol. (2014) 154:291-303. doi: 10.1016/j.aquatox.2014. 05.025

134. Colovic MB, Krstic DZ, Lazarevic-Pasti TD, Bondzic AM, Vasic VM. Acetylcholinesterase inhibitors: pharmacology and toxicology. Curr Neuropharmacol. (2013) 11:315-35. doi: 10.2174/1570159X1131103 0006
135. Houeto P, Bindoula G, Hoffman JR. Ethylenebisdithiocarbamates and ethylenethiourea: possible human health hazards. Environ Health Perspect. (1995) 103:568-73. doi: 10.1289/ehp.95103568

136. Hedenstedt A, Rannug U, Ramel C, Wachtmeister CA. Mutagenicity and metabolism studies on 12 thiuram and dithiocarbamate compounds used as accelerators in the Swedish rubber industry. Mutat Res Toxicol. (1979) 68:313-25. doi: 10.1016/0165-1218(79)90164-2

137. Jardim ANO, Mello DC, Brito AP, van der Voet H, Boon PE, Caldas ED. Probabilistic dietary risk assessment of triazole and dithiocarbamate fungicides for the Brazilian population. Food Chem Toxicol. (2018) 118:31727. doi: $10.1016 /$ j.fct.2018.05.002

138. van Wendel de Joode B, Mora AM, Cordoba L, Cano JC, Quesada R, Faniband $\mathrm{M}$, et al. Aerial application of mancozeb and urinary ethylene thiourea (ETU) concentrations among pregnant women in Costa Rica: the Infants' Environmental Health Study (ISA). Environ Health Perspect. (2014) 122:1321-8. doi: 10.1289/ehp.1307679

139. Huang HS, Lee KW, Ho CH, Hsu CC, Su SB, Wang JJ, et al. Increased risk for hypothyroidism after anticholinesterase pesticide poisoning: a nationwide population-based study. Endocrine. (2017) 57:436-44. doi: 10.1007/s12020-017-1373-7

140. Medda E, Santini F, De Angelis S, Franzellin F, Fiumalbi C, Perico A, et al. Iodine nutritional status and thyroid effects of exposure to ethylenebisdithiocarbamates. Environ Res. (2017) 154:152-9. doi: 10.1016/j.envres.2016.12.019

141. Laisi A, Tuominen R, Männistö P, Savolainen K, Mattila J. The effect of maneb, zineb, and ethylenethiourea on the humoral activity of the pituitary-thyroid axis in rat. Arch Toxicol Suppl. (1985) 8:253-8. doi: 10.1007/978-3-642-69928-3_37

142. Pandey SP, Mohanty B. The neonicotinoid pesticide imidacloprid and the dithiocarbamate fungicide mancozeb disrupt the pituitarythyroid axis of a wildlife bird. Chemosphere. (2015) 122:227-34. doi: 10.1016/j.chemosphere.2014.11.061

143. Kackar R, Srivastava MK, Raizada RB. Studies on rat thyroid after oral administration of mancozeb: morphological and biochemical evaluations. $J$ Appl Toxicol. (1997) 17:369-75.

144. Chernick M, Yu Y, Teraoka H, Nanba S, Hinton DE, Wang F, et al. The case for thyroid disruption in early life stage exposures to thiram in zebrafish (Danio rerio). Gen Comp Endocrinol. (2018) 271:73-81. doi: 10.1016/j.ygcen.2018.11.003

145. Marinovich M, Guizzetti M, Ghilardi F, Viviani B, Corsini E, Galli CL. Thyroid peroxidase as toxicity target for dithiocarbamates. Arch Toxicol. (1997) 71:508-12. doi: 10.1007/s00204 0050420

146. Elliott M, Farnham AW, Janes NF, Khambay BPS. Insecticidal activity of the pyrethrins and related compounds. Part XII: $\alpha$-substituted-3-phenoxybenzyl esters. Pestic Sci. (1982) 13:407-14. doi: 10.1002/ps.2780130411

147. Anadón A, Martínez-Larrañaga MR, Martínez MA. Use and abuse of pyrethrins and synthetic pyrethroids in veterinary medicine. Vet J. (2009) 182:7-20. doi: 10.1016/j.tvil.2008.04.008

148. Elbert A, Haas M, Springer B, Thielert W, Nauen R. Applied aspects of neonicotinoid uses in crop protection. Pest Manag Sci. (2008) 64:1099-105. doi: $10.1002 /$ ps. 1616

149. Saillenfait AM, Ndiaye D, Sabaté JP. Pyrethroids: exposure and health effects - an update. Int J Hyg Environ Health. (2015) 218:281-92. doi: 10.1016/j.ijheh.2015.01.002

150. Du G, Shen O, Sun H, Fei J, Lu C, Song L, et al. Assessing hormone receptor activities of pyrethroid insecticides and their metabolites in reporter gene assays. Toxicol Sci. (2010) 116:58-66. doi: 10.1093/toxsci/kfq120

151. Juraske R, Mutel CL, Stoessel F, Hellweg S. Life cycle human toxicity assessment of pesticides: comparing fruit and vegetable diets in Switzerland and the United States. Chemosphere. (2009) 77:939-45. doi: 10.1016/j.chemosphere.2009.08.006

152. Laskowski DA. Physieal and chemie al properties of pyrethroids. Rev Env Contam Toxieol. (2002) 174:49-170. doi: 10.1007/978-1-4757-4260-2_3

153. Ge J, Cong J, Sun Y, Li G, Zhou Z, Qian C, Liu F. Determination of endocrine disrupting chemicals in surface water and industrial wastewater from Beijing, China. Bull Environ Contam Toxicol. (2010) 84:401-5. doi: $10.1007 / \mathrm{s} 00128-010-9958-3$ 
154. Hladik ML, Kuivila KM. Assessing the occurrence and distribution of pyrethroids in water and suspended sediments. J Agric Food Chem. (2009) 57:9079-85. doi: 10.1021/jf9020448

155. Zhang J, Yoshinaga J, Hisada A, Shiraishi H, Shimodaira K, Okai T, et al. Prenatal pyrethroid insecticide exposure and thyroid hormone levels and birth sizes of neonates. Sci Total Environ. (2014) 488-9:275-9. doi: 10.1016/j.scitotenv.2014.04.104

156. Li Z, Nie J, Lu Z, Xie H, Kang L, Chen Q, et al. Cumulative risk assessment of the exposure to pyrethroids through fruits consumption in China Based on a 3-year investigation. Food Chem Toxicol. (2016) 96:234-43. doi: 10.1016/j.fct.2016.08.012

157. Zhang J, Hisada A, Yoshinaga J, Shiraishi H, Shimodaira K, Okai T, et al. Exposure to pyrethroids insecticides and serum levels of thyroidrelated measures in pregnant women. Environ Res. (2013) 127:16-21. doi: 10.1016/j.envres.2013.10.001

158. Nassr ACC, Arena AC, Toledo FC, Bissacot DZ, Fernandez CDB, SpinardiBarbisan ALT, et al. Effects of gestational and lactational fenvalerate exposure on immune and reproductive systems of male rats. J Toxicol Environ Heal A Curr Issues. (2010) 73:952-64. doi: 10.1080/15287391003751745

159. Pérez JJ, Williams MK, Weerasekera G, Smith K, Whyatt RM, Needham LL, Barr DB. Measurement of pyrethroid, organophosphorus, and carbamate insecticides in human plasma using isotope dilution gas chromatographyhigh resolution mass spectrometry. J Chromatogr B Anal Technol Biomed Life Sci. (2010) 878:2554-62. doi: 10.1016/j.jchromb.2010.03.015

160. Kaul PP, Rastogi A, Hans RK, Seth TD, Seth PK, Srimal RC. Fenvalerateinduced alterations in circulatory thyroid hormones and calcium stores in rat brain. Toxicol Lett. (1996) 89:29-33. doi: 10.1016/S0378-4274(96) 03778-2

161. Giray B, Cağlayan A, Erkekoğlu P, Hincal F. Fenvalerate exposure alters thyroid hormone status in selenium- and/or iodine-deficient rats. Biol Trace Elem Res. (2010) 135:233-41. doi: 10.1007/s12011-009-8506-7

162. Wang B, Liu JJ, Wang Y, Fu L, Shen R, Yu Z, et al. Maternal fenvalerate exposure induces fetal intrauterine growth restriction through disrupting placental thyroid hormone receptor signaling. Toxicol Sci. (2017) 157:37786. doi: $10.1093 /$ toxsci/kfx052

163. Chang J, Hao W, Xu Y, Xu P, Li W, Li J, Wang H. Stereoselective degradation and thyroid endocrine disruption of lambda-cyhalothrin in lizards (Eremias argus) following oral. Environ Pollut. (2017) 232:300-9. doi: 10.1016/j.envpol.2017.09.072

164. Tu W, Xu C, Jin Y, Lu B, Lin C, Wu Y, Liu W. Permethrin is a potential thyroid-disrupting chemical: In vivo and in silico envidence. Aquat Toxicol. (2016) 175:39-46. doi: 10.1016/j.aquatox.2016. 03.006

165. Tu W, Xu C, Lu B, Lin C, Wu Y, Liu W. Acute exposure to synthetic pyrethroids causes bioconcentration and disruption of the hypothalamuspituitary-thyroid axis in zebrafish embryos. Sci Total Environ. (2016) 542:876-85. doi: 10.1016/j.scitotenv.2015.10.131

166. Xu C, Li X, Jin M, Sun X, Niu L, Lin C, et al. Early life exposure of zebrafish (Danio rerio) to synthetic pyrethroids and their metabolites: a comparison of phenotypic and behavioral indicators and gene expression involved in the HPT axis and innate immune system. Environ Sci Pollut Res Int. (2018) 25:12992-3003. doi: 10.1007/s11356-018-1542-0

167. Giroux M, Gan J, Schlenk D. The Effects of bifenthrin and temperature on the endocrinology of Juvenile Chinook Salmon. Environ Toxicol Chem. (2019) 38:852-61. doi: 10.1002/etc.4372

168. Tingle CCD, Rother JA, Dewhurst CF, Lauer S, King WJ. Fipronil: environmental fate, ecotoxicology, and human health concerns. In: Ware GW, editor. Reviews of Environmental Contamination and Toxicology. Reviews of Environmental Contamination and Toxicology. Vol. 176. New York, NY: Springer (2003). p. 1-66. doi: 10.1007/978-1-4899-7283-5_1

169. Kim YA, Yoon YS, Kim HS, Jeon SJ, Cole E, Lee J, et al. Distribution of fipronil in humans, and adverse health outcomes of in utero fipronil sulfone exposure in newborns. Int J Hyg Environ Health. (2019) 222:524-32. doi: 10.1016/j.ijheh.2019.01.009

170. Simon-Delso N, Amaral-Rogers V, Belzunces LP, Bonmatin JM, Chagnon M, Downs C, et al. Systemic insecticides (neonicotinoids and fipronil): trends, uses, mode of action and metabolites. Environ Sci Pollut Res. (2015) 22:5-34. doi: $10.1007 / \mathrm{s} 11356-014-3470-\mathrm{y}$
171. Stone WW, Gilliom RJ, Ryberg KR. Pesticides in U.S. Streams and Rivers: Occurrence and Trends during 1992-2011. Environ Sci Technol. (2014) 48:11025-30. doi: 10.1021/es5025367

172. Bonmatin J, Giorio C, Girolami V, Goulson D, Kreutzweiser DP. Environmental fate and exposure; neonicotinoids and fipronil. Environ Sci Pollut Res Int. (2015) 22:35-67. doi: 10.1007/s11356-014$3332-7$

173. Mahler BJ, Van Metre PC, Wilson JT, Musgrove M, Zaugg SD, Burkhardt MR. Fipronil and its degradates in indoor and outdoor dust. Environ Sci Technol. (2009) 43:5665-70. doi: 10.1021/es901292a

174. Li X, Li H, Ma W, Guo Z, Li X, Song S, Tang H. Development of precise GC-EI-MS method to determine the residual fi pronil and its metabolites in chicken egg. Food Chem. (2019) 281:85-90. doi: 10.1016/j.foodchem.2018.12.041

175. Fipronil Egg Scandal: What We Know - BBC News. (2017). Available online at: https://www.bbc.com/news/world-europe-40878381 (accessed March 26, 2019).

176. Holder PJ, Jones A, Tyler CR, Cresswell JE. Fipronil pesticide as a suspect in historical mass mortalities of honey bees. Proc Natl Acad Sci USA. (2018) 115:13033-8. doi: 10.1073/pnas.1804934115

177. General Court of the European Union. General Court of the European Union Press Release No 68/18 The General Court Confirms the Validity of the Restrictions Introduced at EU Level in 2013 Against the Insecticides Clothianidin, Thiamethoxam and Imidacloprid Because of the Risks Those Substa. (2018).

178. European Commission. EU Pesticides Database - Fipronil. Available online at: http://ec.europa.eu/food/plant/pesticides/eu-pesticides-database/public/? event=activesubstance.detail\&language $=\mathrm{EN} \&$ selectedID $=1363 \quad$ (accessed April 10, 2019).

179. Caboni P, Sammelson RE, Casida JE. Phenylpyrazole insecticide photochemistry, metabolism, and GABAergic action: ethiprole compared with fipronil. J Agric Food Chem. (2003) 51:7055-61. doi: 10.1021/jf03 04391

180. Wang X, Martínez MA, Wu Q, Ares I, Martínez-Larrañaga MR, Anadón A, et al. Fipronil insecticide toxicology: oxidative stress and metabolism. Crit Rev Toxicol. (2016) 46:876-99. doi: 10.1080/10408444.2016. 1223014

181. Hainzl D, Cole LM, Casida JE. Mechanisms for selective toxicity of fipronil insecticide and its sulfone metabolite and desulfinyl photoproduct. Chem Res Toxicol. (1998) 11:1529-35. doi: 10.1021/tx980157t

182. Gunasekara AS, Truong T, Goh KS, Spurlock F, Tjeerdema RS. Environmental fate and toxicology of fipronil. J Pestic Sci. (2007) 32:189-99. doi: 10.1584/jpestics.R07-02

183. Lacroix MZ, Puel S, Toutain PL, Viguié C. Quantification of fipronil and its metabolite fipronil sulfone in rat plasma over a wide range of concentrations by LC/UV/MS. J Chromatogr B Analyt Technol Biomed Life Sci. (2010) 878:1934-8. doi: 10.1016/j.jchromb.2010.05.018

184. Konwick BJ, Garrison AW, Black MC, Avants JK, Fisk AT. Bioaccumulation, biotransformation, and metabolite formation of fipronil and chiral legacy pesticides in rainbow trout. Environ Sci Technol. (2006) 40:2930-6. doi: $10.1021 /$ es0600678

185. Romero A, Ramos E, Ares I, Castellano V, Martínez M, Anadón A, Martínez MA. Fipronil sulfone induced higher cytotoxicity than fi pronil in SH-SY5Y cells: protection by antioxidants. Toxicol Lett. (2016) 252:42-9. doi: 10.1016/j.toxlet.2016.04.005

186. Leghait J, Gayrard V, Picard-Hagen N, Camp M, Perdu E, Toutain $\mathrm{PL}$, et al. Fipronil-induced disruption of thyroid function in rats is mediated by increased total and free thyroxine clearances concomitantly to increased activity of hepatic enzymes. Toxicology. (2009) 255:38-44. doi: 10.1016/j.tox.2008.09.026

187. Roques BB, Lacroix MZ, Puel S, Gayrard V, Picard-Hagen N, Jouanin I, et al. CYP450-Dependent biotransformation of the insecticide fipronil into fipronil sulfone can mediate fipronil-induced thyroid disruption in rats. Toxicol Sci. (2012) 127:29-41. doi: 10.1093/toxsci/kfs094

188. Mohamed F, Senarathna L, Percy A, Abeyewardene M, Eaglesham G, Cheng $\mathrm{R}$, et al. Acute human self-poisoning with the $\mathrm{N}$-phenylpyrazole insecticide fipronil-a GABA A gated chloride channel blocker. J Toxicol Clin Toxicol. (2004) 42:955-63. doi: 10.1081/CLT-200041784 
189. Herin F, Boutet-robinet E, Levant A, Dulaurent S, Manika M, Galatry-bouju F, et al. Thyroid function tests in persons with occupational exposure to fipronil. Thyroid. (2011) 21: 701-6. doi: 10.1089/thy.2010.0449

190. Razaz N, Boyce WT, Brownell M, Jutte D, Tremlett H, Marrie RA, et al. Five-minute Apgar score as a marker for developmental vulnerability at 5 years of age. Arch Dis Child Fetal Neonatal Ed. (2016) 101:F114-20. doi: 10.1136/archdischild-2015-308458

191. Hurley PM, Hill RN, Whiting RJ. Mode of carcinogenic action of pesticides inducing thyroid follicular cell tumors in rodents. Environ Health Perspect. (1998) 106:437-45. doi: 10.1289/ehp.98106437

192. Ferreira M, De Oliveira PR, Denardi SE, Bechara GH, MAthias MIC. Fipronil (active ingredient of acaricide frontline ${ }^{\circledR}$ ) acting on the mice thyroid. Microsc Res Tech. (2012) 75:265-70. doi: 10.1002/jemt.21053

193. Moser VC, Stewart N, Freeborn DL, Crooks J, MacMillan DK, Hedge JM, et al. Assessment of serum biomarkers in rats after exposure to pesticides of different chemical classes. Toxicol Appl Pharmacol. (2015) 282:161-74. doi: 10.1016/j.taap.2014.11.016

194. Roques B, Leghait J, Martin PGP, Pineau T, Viguie C. The nuclear receptors pregnane $\mathrm{X}$ receptor and constitutive androstane receptor contribute to the impact of fipronil on hepatic gene expression linked to thyroid hormone metabolism. Biochem Pharmacol. (2013) 86:997-1039. doi: 10.1016/j.bcp.2013.08.012

195. Lu M, Du J, Zhou P, Chen H, Lu C, Zhang Q. Endocrine disrupting potential of fipronil and its metabolite in reporter gene assays. Chemosphere. (2015) 120:246-51. doi: 10.1016/j.chemosphere.2014.07.015

196. Minnema DJ, Li AA, Collier RH, Sheets LP, Peffer RC, Creek MR. A critical review of neonicotinoid insecticides for developmental neurotoxicity. Crit Rev Toxicol. (2015) 46:153-90. doi: 10.3109/10408444.2015.1090948

197. Pollak P. Fine Chemicals. Hoboken, NJ: John Wiley and Sons, Inc. (2011).

198. Rose PH. Chapter 6. Nicotine and the neonicotinoids. Royal Society of Chemistry. p. 184-220. doi: 10.1039/9781849733007-00184 Available online at: https://pubs.rsc.org/en/content/chapter/9781849733007-00184/ 978-1-84973-300-7

199. Gunier RB, Bradman A, Harley KG, Kogut K, Eskenazi B. Prenatal residential proximity to agricultural pesticide use and IQ in 7-year-old children. Environ Heal Perspect. (2017) 125:057002. doi: 10.1289/EHP504

200. Mesnage R, Biserni M, Genkova D, Wesolowski L, Antoniou MN. Evaluation of neonicotinoid insecticides for oestrogenic, thyroidogenic and adipogenic activity reveals imidacloprid causes lipid accumulation. J Appl Toxicol. (2018) 38:1483-91. doi: 10.1002/jat.3651

201. Xiang D, Han J, Yao T, Wang Q, Zhou B, Mohamed AD, Zhu G. Structurebased investigation on the binding and activation of typical pesticides with thyroid receptor. Toxicol Sci. (2017) 160:205-16. doi: 10.1093/toxsci/kfx177

202. Bhaskar R, Mohanty B. Pesticides in mixture disrupt metabolic regulation: In silico and in vivo analysis of cumulative toxicity of mancozeb and imidacloprid on body weight of mice. Gen Comp Endocrinol. (2014) 205:22634. doi: 10.1016/j.ygcen.2014.02.007

203. Zhang ZY, Yu XY, Wang DL, Yan HJ, Liu XJ. Acute toxicity to zebrafish of two organophosphates and four pyrethroids and their binary mixtures. Pest Manag Sci. (2010) 66:84-9. doi: 10.1002/ps.1834

204. Kortenkamp A. Ten years of mixing cocktails: a review of combination effects of endocrine-disrupting chemicals. Environ Health Perspect. (2007) 115(Suppl. 1):98-105. doi: 10.1289/ehp.9357

205. Scholze M, Silva E, Kortenkamp A. Extending the applicability of the dose addition model to the assessment of chemical mixtures of partial agonists by using a novel toxic unit extrapolation method. PLoS ONE. (2014) 9:e88808. doi: 10.1371/journal.pone.0088808

206. Martin O V, Martin S, Kortenkamp A. Dispelling urban myths about default uncertainty factors in chemical risk assessment - sufficient protection against mixture effects? Environ Health. (2013) 12:53. doi: 10.1186/1476-069X-12-53

207. Choudhury H, Hertzberg R, Rice G, Cogliano J, Mukerjee D, Teuscler L. Supplementary Guidance for Conducting Health Risk Assessment of Chemical Mixtures. Risk Assess Fourm (2000). EPA/630/R-00/002.

208. Rider C V., LeBlanc GA. An integrated addition and interaction model for assessing toxicity of chemical mixtures. Toxicol Sci. (2005) 87:520-8. doi: 10.1093/toxsci/kfi247

209. Wade MG, Parent S, Finnson KW, Foster W, Younglai E, McMahon A, et al. Thyroid toxicity due to subchronic exposure to a complex mixture of 16 organochlorines, lead, and cadmium. Toxicol Sci. (2002) 67:207-18. doi: 10.1093/toxsci/67.2.207

210. Fini J, Mughal BB, Le Mével S, Leemans M, Lettmann M, Spirhanzlova P, et al. Human amniotic fluid contaminants alter thyroid hormone signalling and early brain development in Xenopus embryos. Sci Rep. (2017) 7:43786. doi: 10.1038/srep43786

211. EPA US. Guidance for health risk assessment of chemical mixtures. Federal Register 51. Risk Assessment Forum. US Environmental Protection Agency, Washington, DC (1986). p. 34014-25.

212. Bornehag C, Gennings C. A novel approach to chemical mixture risk assessment - Linking data from population based epidemiology and experimental animal tests. Toxicol Lett. (2018) 295:S52. doi: 10.1016/j.toxlet.2018.06.1203

213. Flippin JL, Hedge JM, DeVito MJ, Leblanc GA, Crofton KM. Predictive modeling of a mixture of thyroid hormone disrupting chemicals that affect production and clearance of thyroxine. Int J Toxicol. (2009) 28:368-81. doi: 10.1177/1091581809341883

214. Wu S, Li X, Liu X, Yang G, An X, Wang Q, et al. Joint toxic effects of triazophos and imidacloprid on zebrafish (Danio rerio). Environ Pollut. (2018) 235:470-81. doi: 10.1016/j.envpol.2017. 12.120

215. Du L, Li S, Qi L, Hou Y, Zeng Y, Xu W, et al. Metabonomic analysis of the joint toxic action of long-term low-level exposure to a mixture of four organophosphate pesticides in rat plasma. Mol Biosyst. (2014) 10:1153-1161. doi: 10.1039/C4MB00044G

216. Pandey SP, Mohanty B. Disruption of the hypothalamic-pituitary-thyroid axis on co-exposures to dithiocarbamate and neonicotinoid pesticides: Study in a wildlife bird, Amandava amandava. Neurotoxicology. (2017) 60:16-22. doi: 10.1016/j.neuro.2017.02.010

217. Pandey SP, Tsutsui K, Mohanty B. Endocrine disrupting pesticides impair the neuroendocrine regulation of reproductive behaviors and secondary sexual characters of red munia (Amandava amandava). Physiol Behav. (2017) 173:15-22. doi: 10.1016/j.physbeh.2017. 01.030

218. Landrigan PJ, Lambertini L, Birnbaum LS. A research strategy to discover the environmental causes of autism and neurodevelopmental disabilities. Environ Health Perspect. (2012) 120:2012-5. doi: 10.1289/ehp.11 04285

219. Howdeshell KL. A model of the development of the brain as a construct of the thyroid system developing a timeline model of thyroid system and brain. Environ Health Perspect. (2002) 110:337-348. doi: 10.1289/ehp. 02110s3337

220. Knudsen GA, Hall SM, Richards AC, Birnbaum LS. TBBPA disposition and kinetics in pregnant and nursing Wistar Han IGS rats. Chemosphere. (2018) 192:5-13. doi: 10.1016/j.chemosphere.2017. 10.122

221. $\mathrm{Mu} \mathrm{X}$, LeBlanc GA. Synergistic interaction of endocrine-disrupting chemicals: model development using an ecdysone receptor antagonist and a hormone synthesis inhibitor. Environ Toxicol Chem. (2004) 23:1085-91. doi: 10.1897/03-273

222. Sharma RP, Schuhmacher M, Kumar V. Review on crosstalk and common mechanisms of endocrine disruptors: Scaffolding to improve PBPK/PD model of EDC mixture. Environ Int. (2017) 99:1-14. doi: 10.1016/j.envint.2016.09.016

223. Chapman TJ, Hillman SE, Boul LA, Kassotis CD, Dell CO, Robert J, et al. Developmental exposure to a mixture of 23 chemicals associated with unconventional oil and gas operations alters the immune system of mice. Toxicol Sci. (2018) 163:639-54. doi: 10.1093/toxsci/kfy066.

224. Robert J, Mcguire CC, Kim F, Nagel SC, Price SJ, Lawrence P, et al. Water contaminants associated with unconventional oil and gas extraction cause immunotoxicity to amphibian tadpoles. Toxicol Sci. (2018) 166:39-50. doi: 10.1093/toxsci/kfy179

225. Grandjean P, Andersen EW. Serum vaccine antibody concentrations in children exposed to perfluorinated compounds. JAMA. (2012) 307:391-7. doi: 10.1001/jama.2011.2034

226. Colborn T. Clues from wildlife to create an assay for thyroid system disruption. Environ Health Perspect. (2002) 110(Suppl):363-7. doi: $10.1289 /$ ehp.02110s3363 
227. Milner BAM, Boyd IL. Toward pesticidovigilance. Science. (2017) 357:12324. doi: $10.1126 /$ science.aan 2683

228. O'Shaughnessy KL, Thomas SE, Spring SR, Ford JL, Ford RL, Gilbert ME. A transient window of hypothyroidism alters neural progenitor cells and results in abnormal brain development. Sci Rep. (2019) 9:4662. doi: 10.1038/s41598-019-40249-7

229. Demeneix B, Slama R. Requested by the PETI committee endocrine disruptors: from scientific evidence to human health protection (2019).

230. Gennings C, Shu H, Rudén C, Öberg M, Lindh C, Kiviranta H, Bornehag C. Incorporating regulatory guideline values in analysis of epidemiology data. Environ Int. (2018) 120:535-43. doi: 10.1016/j.envint.2018. 08.039

231. Andersson N, Arena M, Auteri D, Barmaz S, Grignard E, Kienzler A, et al. Guidance for the identification of endocrine disruptors in the context of Regulations (EU) No 528/2012 and (EC) No 1107/2009. EFSA J. (2018) 16:1-135. doi: 10.2903/j.efsa.2018. 5311
232. EFSA. Guidance on biological relevance. Draft version for public consultation. EFSA J. (2019) 1-60.

Conflict of Interest: BD is co-founder of Watchfrog but receives no financial compensation.

The remaining authors declare that the research was conducted in the absence of any commercial or financial relationships that could be construed as a potential conflict of interest.

Copyright (c) 2019 Leemans, Couderq, Demeneix and Fini. This is an open-access article distributed under the terms of the Creative Commons Attribution License (CC $B Y)$. The use, distribution or reproduction in other forums is permitted, provided the original author(s) and the copyright owner(s) are credited and that the original publication in this journal is cited, in accordance with accepted academic practice. No use, distribution or reproduction is permitted which does not comply with these terms. 